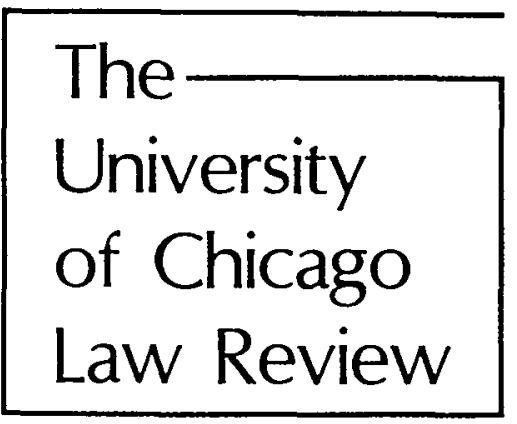

1993 by The University of Chicago

\title{
Decentering Decentralization
}

\author{
Jerry Frug†
}

The fear of making the national government the predominant power in the country is as old as America. ${ }^{1}$ But in the late twentieth century many people think that there is no alternative. Genuine decentralization of power, the traditional argument runs, is no longer possible. The world is too complex, local resources too inadequate, local power too threatening to minorities, the country's problems too interconnected to rely on local decisionmaking. If most government decisionmaking were decentralized today, cities would selfishly seek to evade responsibility for problems ranging from the disposal of toxic waste to the location of centers for the homeless ("Not In My Backyard"). They would attempt to enhance the prosperity of their own residents even if their actions threatened the national economy. They would invade the rights of their most powerless citizens. And they would be unable even to address problems that cut across local boundaries-such as the en-

$\dagger$ Professor of Law, Harvard University. 01993 by Jerry Frug. Thanks to Betsy Bartholet, Nathaniel Berman, Thad Davis, David Kennedy, Matt Kramer, Frank Michelman, David Nino, and Todd Rakoff for their helpful comments and assistance. This Article-the first I have published without the benefit of her comments-was written in memory of, and is dedicated to, my wife, Mary Joe Frug.

${ }^{1}$ See, for example, Federalist 17 (Hamilton) in J.R. Pole, The American Constitution: For and Against 164 (Hill \& Wang, 1987). For an evaluation of these fears, see Michael W. McConnell, Federalism: Evaluating the Founders' Design, 54 U Chi L Rev 1484 (1987). 
vironment and transportation-let alone pay for the necessary programs. Decentralization of political power is therefore either an im- possible dream-nostalgia for a past long since overtaken by events-or a nightmare that would quickly undermine the country's power and efficiency.

In this Article I reject this traditional understanding of decentralized power in America. The traditional account attributes to localities the power of self-assertion associated in our liberal culture with an autonomous individual. It presents localities as being able to do whatever they want: they can act in their own self-interest, cooperate with others on their own terms, and cause harm to those who disagree with them. The political term for this form of autonomy is "sovereignty." Indeed, these days the same term is often used to describe the extent to which individuals, as well as nations, can define and implement their own self-interest ("consumer sovereignty"). The traditional version of decentralization envisions cities as sovereign in this sense: they are entitled to be selfish, like consumers, on a collective rather than an individual basis. $^{3}$

The problem with the traditional account of decentralization lies in this understanding of local power. By modeling cities on the autonomous individual and the nation-state, the traditional account ascribes to all three entities the same kind of subjectivity. All three, in the words of postmodern theory, have a centered sense of self. All three define themselves as radically separate from others, all three discover their desires by looking within them-

2 The sovereign is "above or superior to all others ... holding the position of ruler." Webster's New World Dictionary of American English 1283 (Simon and Schuster, 3d ed, 1988).

${ }^{3}$ For extensive analysis of this picture of decentralization, see Richard Briffault, Our Localism: Part I-The Structure of Local Government Law, 90 Colum L Rev 1 (1990); Richard Briffault, Our Localism: Part II-Localism and Legal Theory, 90 Colum L Rev 346 (1990); Gordon L. Clark, Judges and the Cities 60-81 (Chicago, 1985). Briffault himself envisions decentralization in these terms. See, for example, his definition of power, 90 Colum $\mathrm{L}$ Rev at 112; his view of inter-local cooperation, id at 433; and his definition of localism, id at 444. Paul Peterson, in his influential book, City Limits, explicitly rejects the nation-state model for cities, Paul E. Peterson, City Limits 3 (Chicago, 1981), but he also adopts the traditional model of decentralization. He treats cities as self-interested sovereigns-just like nation-states-while, at the same time, he argues that, unlike nation-states, they have a limited capacity to engage in certain types of activity. Peterson's traditional approach is apparent, for example, in his acceptance of the conventional suburb/city divide. Compare id at 104-06 with text accompanying notes 257-73. For an extended attempt to square this traditional concept of decentralization with the need to protect individuals from discrimination on the basis of geographical location, see Gerald L. Neuman, Territorial Discrimination, Equal Protection, and Self-Determination, $135 \mathrm{U} \mathrm{Pa} \mathrm{L}$ Rev 261 (1987). 
selves, and all three have a core of self-interest with which they can be in touch. ${ }^{4}$ The traditional account thus seeks to decenter power without questioning-without decentering-the kind of subject that exercises that power. The subjectivity associated with the nation-state is simply recentered, moved from the national government to the localities.

Not surprisingly, the possibility of decentralizing power becomes severely limited when it is based on a sovereign subjectivity that is transplanted but not transformed. No one could trust such an entity to exercise unsupervised power. It presents too much danger to outsiders and to its own members. Indeed, as Foucault suggests, fear of sovereign power is so common that it is routinely converted into a subjected sovereignty, a sovereignty limited by some other sovereignty.

Humanism [has] invented a whole series of subjected sovereignties: the soul (ruling the body, but subjected to God), consciousness (sovereign in a context of judgment, but subjected to the necessities of truth), the individual (a titular control of personal rights subjected to the laws of nature and society), basic freedom (sovereignty within, but accepting the demands of an outside world and "aligned with destiny"). ${ }^{5}$

\footnotetext{
- Although this definition of the centered subject is my own, it is designed to reflect a commonly articulated conception of the self. To cite but one example, Michael Sandel includes the following in his account of the Kantian conception of the self:

The subject is the something 'back there', antecedent to any particular experience, that unifies our diverse perceptions and holds them together in a single consciousness. It provides the principle of unity without which our self-perceptions would be nothing more than a stream of disconnected and ever-changing representations, the perceptions of no one. And while we cannot grasp this principle empirically, we must presume its validity if we are to make sense of self-knowledge at all.

Michael J. Sandel, Liberalism and the Limits of Justice 8 (Cambridge, 1982). Sandel is describing what I am calling the centered subject-the concept of self as self-presence. See also Jacques Derrida, Structure, Sign, and Play in the Discourse of the Human Sciences, in Writing and Difference 278, 278-82 (Chicago, 1978). A number of authors have argued that Sandel is mistaken when he asserts that contemporary liberals, such as John Rawls, rely on such a conception of the self. See, for example, Richard Rorty, Objectivity, Relativism and Truth: Philosophical Papers Volume I 184-89 (Cambridge, 1991); Amy Gutmann, Communitarian Critics of Liberalism, 14 Phil and Pub Affairs 308 (1985). See also text accompanying notes 106-08. Even if these critics are right-even if no one has ever actually fully embraced the concept of a radically separate subject-references to such an autonomous subject are certainly a familiar part of our political and moral discourse. This conception has had a particularly powerful impact on local government law.

- Michel Foucault, Language, Counter-Memory, Practice 221 (Cornell, 1977).
} 
Decentralized localities have a similarly subjected sovereignty: they can exercise power, but they are simultaneously subject to the power of the state.

Of course, the notion of subjected sovereignty has always allowed some degree of decentralized power. Indeed, although suburbs, like cities, are subject to state control, many suburbs have profited greatly from the positive associations with the notion of sovereignty. They have separated themselves from the city and promoted their own self-interest regardless of the impact on city residents. ${ }^{6}$ As a result, millions of people have escaped city problems by crossing the boundary between city and suburb. Major American cities, on the other hand, have largely suffered from the negative associations with the notion of sovereignty. Local government law has denied cities the power to confront their problems in their own way. City policies dealing with the exodus of local businesses and unemployment, for example, have been treated as undermining the national economy; city policies on crime, homelessness, and racism have been treated as threatening the rights of citizens." This combination of suburban power and city powerlessness has had disastrous consequences for American life. It has segregated many of America's metropolitan areas into "two nations": rich and poor, white and black, expanding and contracting. ${ }^{8}$ By dividing prosperous suburbs from decaying inner cities, it has denied the poor access to jobs and increased interracial inequality. ${ }^{9}$ And, in the process, it has destroyed millions of acres of natural beauty and fostered a "cliché conformity as far as the eye can see." 10 Yet

${ }^{6}$ See Briffault, 90 Colum L Rev at 356-92 (cited in note 3).

: City of Oakland v Oakland Raiders, 174 Cal 3d 414, 220 Cal Rptr 153, cert denied 478 US 1007 (1985); (business relocation); United Bldg. \& Constr. Trades Council v Mayor and Council, 465 US 208, 218-21 (1984) (unemployment); Dwyer v Farrell, 193 Conn 7, 475 A2d 257, 260-61 (1984) (crime); Seawall Associates v City of New York, 74 NY2d 92, 542 NE2d 1059, 1060-61 (1989) (homelessness); R.A.V. $v$ City of St. Paul, 112 S Ct 2538, 254750 (1992) (racism).

${ }^{8}$ The phrase "two nations," associated in the nineteenth century with Disraeli, see Benjamin Disraeli, Sybil: or The Two Nations (Mayflower, 1927), has been adopted by many analysts of modern America. See, for example, Robert Fishman, Bourgeois Utopias: The Rise and Fall of Suburbia 198-205 (Basic Books, 1987); Andrew Hacker, Two Nations: Black and White, Separate, Hostile, Unequal (Charles Scribner's Sons, 1992). For an analysis of the impact of residential segregation on American life, see Robert B. Reich, The Work of Nations: Preparing Ourselves for 21st-Century Capitalism 268-81 (Knopf, 1991). "Tell me someone's zip code and I can predict what they eat, drink, and drive-even think." Id at 277.

- See, for example, William Julius Wilson, The Truly Disadvantaged: The Inner City, the Underclass, and Public Policy (Chicago, 1987).

${ }^{10}$ Ada Louise Huxtable, An Alternative to "Slurbs," in Louis H. Masotti and Jeffrey K. Hadden, eds, Suburbia in Transition 185, 187 (NY Times Co., 1974). See generally Fish- 
decentralizing genuine power to both cities and suburbs seems inconceivable-and undesirable-as long as decentralization is understood in the traditional way.

Proponents of decentralization, however, need not attribute to cities the subjectivity of the centered self. In my view, the values of decentralization-the freedom gained from the ability to participate in the basic societal decisions that affect one's life, the creativity generated by the capacity to experiment in solving public problems and to tailor possible solutions to local needs, and the energy derived from democratic forms of organization ${ }^{11}$ - are better defended by basing decentralization on alternative theories of the subject. In this Article, I redefine decentralization of power by building on the vast literature of critique of the centered subject, ${ }^{12}$

man Bourgeois Utopias at 198-205 (cited in note 8); Kenneth T. Jackson, Crabgrass Frontier: The Suburbanization of The United States 246-82 (Oxford, 1985); Jon C. Teaford, The Rough Road to Renaissance: Urban Revitalization in America, 1940-1985 (Johns Hopkins, 1990); Jon C. Teaford, City and Suburb: The Political Fragmentation of Metropolitan America, 1850-1970 (Johns Hopkins, 1979).

"II I elaborate on and defend these values in Jerry Frug, Administrative Democracy, 40 U Toronto L J 559 (1990), and Gerald E. Frug, The City as a Legal Concept, 93 Harv L Rev 1057, 1067-73 (1980).

12 Much of twentieth-century thought belongs in this footnote, although historians of the critique usually begin their account of it with references either to Hegel or to Nietzsche. See, for example, Carolyn J. Dean, The Self and Its Pleasures: Bataille, Lacan, and the History of the Decentered Subject 4 (Cornell, 1992) (Hegel); Arthur Kroker, The Possessed Individual: Technology and the French Postmodern 7 (St. Martin's, 1992) (Nietzsche). Suffice it to say here that I include in my idea of the critique of the centered subject those labeled communitarians, see, for example, Charles Taylor, Atomism, in 2 Philosophical Papers: Philosophy and the Human Sciences 187, 209 (Cambridge, 1985); Sandel, Liberalism and the Limits of Justice (cited in note 4); and Michael Walzer, The Communitarian Critique of Liberalism, 18 Political Theory 6 (1990); critical race theorists, see, for example, Kwame Anthony Appiah, In My Father's House: Africa in the Philosophy of Culture (Oxford, 1992); bell hooks, Yearning: Race, Gender, and Cultural Politics (South End Press, 1990); Patricia J. Williams, The Alchemy of Race and Rights: Diary of a Law Professor (Harvard, 1991); critical theorists, see, for example, Theodor Adorno, Subject and Object, in Andrew Arato and Eike Gebhardt, eds, The Essential Frankfurt School Reader 497 (Urizen, 1982); Seyla Benhabib, Situating the Self: Gender, Community and Postmodernism in Contemporary Ethics (Routledge, 1992); Jürgen Habermas, The Theory of Communicative Action (Beacon Press, 1981); feminists, see, for example, Mary Joe Frug, Postmodern Legal Feminism (Routledge, 1992); Martha Minow, Making All the Difference: Inclusion, Exclusion, and American Law (Cornell, 1990); Toril Moi, ed, French Feminist Thought: A Reader (Basil Blackwell, 1987); postmodernists, see, for example, Jean Baudrillard, Simulations (Semiotext, 1983); Charles Jencks, ed, The Post-Modern Reader (St. Martin's Press, 1992); Jean-Francois Lyotard, The Postmodern Condition: A Report on Knowledge (Minnesota, 1984); psychoanalysts and anti-psychoanalysts, see, for example, Mikkel Borch-Jacobsen, The Freudian Subject (Stanford, 1988); Gilles Deleuze and Félix Guattari, Anti-Oedipus: Capitalism and Schizophrenia (Minnesota, 1983); Jacques Lacan, Écrits: A Selection (W.W. Norton, 1977); and structuralists and poststructuralists, see, for example, Roland Barthes, Image, Music, Text (Hill \& Wang, 1977); Foucault, Language, CounterMemory, Practice (cited in note 5); Derrida, Writing and Difference (cited in note 4). The 
a literature that has focused primarily on the individual rather than on collective entities such as cities. ${ }^{13} \mathrm{I}$ offer below a brief introduction to this critique; this introduction is designed to serve as a contrasting background to the ensuing account of the decisive role that the notion of the centered subject now plays in the structure of local government law. Then, in Parts II and III, I analyze two alternative versions of local government law, both organized in terms of a decentered subject. In these sections, I address not only how the definition of city power would change under a revised local government law, but also the ways in which a legal doctrine based on the concept of a decentered self would transform the institutional structure of decentralized power in America.

\section{The Centered Subject}

\section{A. An Initial Account of the Critique of the Centered Subject}

One way to understand the critique of the centered subject is to recognize that describing one's own sense of self-describing oneself, even to oneself-is a creative process. Identifying the self requires the invention of a narrative: the selection, editing, and unifying of countless aspects of memory and desire. It requires the transformation of the multiplicity of one's life into a single account-more accurately, into a series of accounts, since the attempt to establish one's identity has elements of both the synchronic (identity at any particular moment) and the diachronic (continuity over time). ${ }^{14}$ As Nietzsche says in The Will to Power, "[t]he 'subject' is only a fiction." It "It "is not something given, it is

\footnotetext{
literature in the law reviews is also becoming quite extensive. See, for example, James Boyle, Is Subjectivity Possible? The Postmodern Subject in Legal Theory, 62 U Colo L Rev 489 (1991); Drucilla Cornell, Toward a Modern/Postmodern Reconstruction of Ethics, $133 \mathrm{U} \mathrm{Pa}$ L Rev 291 (1985); Angela P. Harris, Race and Essentialism in Feminist Legal Theory, 42 Stan L Rev 581 (1990); David Kennedy, Spring Break, 63 Tex L Rev 1377 (1985); Martha Minow, Identities, 3 Yale J L \& Humanities 97 (1991); Pierre Schlag, The Problem of the Subject, 69 Tex L Rev 1627 (1991); Steven L. Winter, Indeterminacy and Incommensurability in Constitutional Law, 78 Cal L Rev 1443 (1990); and all the articles in For Mary Joe Frug: A Symposium on Feminist Critical Legal Studies and Postmodernism-Part Two: The Politics of Gender Identity, 26 New Eng L Rev 1173, 1173-1537 (1992).

13 But see works cited at notes 23-25.

${ }^{14}$ See Mark C. Taylor, Erring: A Postmodern A/theology 48 (Chicago, 1984). One way to understand the creative nature of self-description is to analyze how the narrative form itself affects what is included and excluded in any account of the self. See generally Hayden White, The Content of the Form: Narrative Discourse and Historical Representation (Johns Hopkins, 1987); W.J.T. Mitchell, ed, On Narrative (Chicago, 1981).

${ }^{15}$ Friedrich Nietzsche, The Will to Power $\$ 370$ at 199 (Random House, Kaufman trans, 1967).
} 
something added and invented and projected behind what there is." "16

A considerable controversy now exists in the literature over this addition, invention, and projection of a "self." Some find its source in culture, ${ }^{17}$ others in political power, ${ }^{18}$ still others in language. ${ }^{19}$ Whichever explanation is adopted, however, all those who describe the decentered self see it as contestable, amenable to the multiple interpretations. Although identity is usually defined in terms of sameness, it is constructed out of a series of differences: the difference between the aspects of life that one attributes to the self and the aspects that one associates with the actions of others;

18 Id $\S 481$ at 267 .

17

The human infant becomes a "self," a being capable of speech and action, only by learning to interact in a human community. The self becomes an individual in that it becomes a "social" being capable of language, interaction and cognition. The identity of the self is constituted by a narrative unity, which integrates what " $\mathrm{I}$ " can do, have done and will accomplish with what you expect of "me," interpret my acts and intentions to mean, wish for me in the future, etc. The Enlightenment conception of the disembodied cogito no less than the empiricist illusion of a substance-like self cannot do justice to those contingent processes of socialization through which an infant becomes a person, acquires language and reason, develops a sense of justice and autonomy, and becomes capable of projecting a narrative into the world of which she is not only the author but the actor as well.

Benhabib, Situating the Self at 5 (cited in note 12).

10

The individual is not to be conceived as a sort of elementary nucleus, a primitive atom, a multiple and inert material on which power comes to fasten or against which it happens to strike, and in so doing subdues or crushes individuals. In fact, it is already one of the prime effects of power that certain bodies, certain gestures, certain discourses, certain desires, come to be identified and constituted as individuals. The individual, that is, is not the vis-a-vis of power; it is, I believe, one of its prime effects. The individual is an effect of power, and at the same time, or precisely to the extent to which it is that effect, it is the element of its articulation. The individual which power has constituted is at the same time its vehicle.

Michel Foucault, Power/Knowledge: Selected Interviews and Other Writings, 1972-1977 98 (Pantheon, 1980).

10

All psychological categories (the ego, the individual, the person) derive from the illusion of substantial identity. But this illusion goes back basically to a superstition that deceives not only common sense but also philosophers-namely, the belief in language and, more precisely, in the truth of grammatical categories. It was grammar (the structure of subject and predicate) that inspired Descartes' certainty that " $\mathrm{I}$ " is the subject of "think," whereas it is rather the thoughts that come to "me": at bottom, faith in grammar simply conveys the will to be the cause of one's thoughts. The subject, the self, the individual are just so many false concepts, since they transform into substances the fictitious unities having at the start only a linguistic reality.

Michel Haar, Nietzsche and Metaphysical Language, in David Allison, ed, The New Nietzsche: Contemporary Styles of Interpretation 17-18 (1977), as quoted in Judith Butler, Gender Trouble: Feminism and The Subversion of Identity 20-21 (Routledge, 1990). 
the difference between the self as described in the present and as seen in the past; the difference between the parts of oneself accepted into the narrative and those rejected; the difference between the describing self and the self being described. The creation of these differences cannot produce a centered subject because neither the interpreter nor the materials being interpreted has a fixed meaning. This is not just a problem of articulation. Determining how to express oneself and not just the demands of the culture, defining a sphere in which personal behavior is not subservient to political power, deciding how to give meaning to one's life-these are questions about how to become a person, how to form one's character. But the "self" who must answer these questions is being challenged by them: the consciousness of the answerer is what is being questioned. Trying to live in a way that is different from, rather than controlled by, cultural or political commands-like trying to give meaning to a self read as a "text"-thus demands more than just continuous effort. It requires endless interpretation, and it is never possible to know for sure what to interpret or who is doing the interpreting. The Arabian poet, Sama Ma'ari, has described a version of this sense of self by saying: "Identities are highly complex, tension filled, contradictory, and inconsistent entities. Only the one who claims to have a simple, definite, and clear-cut identity has an identity problem."2o

This brief account of the critique of the centered subject does not begin to capture the complexities of the topic, but it might nevertheless be adequate to introduce the related problem of group identity. The critique of the centered subject is more familiar when it is applied to groups rather than the self. Treating individuals as a group plainly requires selecting, editing, and unifying disparate elements - the creation of a sameness out of a multitude of differences. Consider any group to which you belong. It does not matter whether the group is defined in terms of geography, race, ethnicity, gender, sexual preference, politics, or some other criteria. Defining what the group has in common and what distinguishes it from outsiders is always a contestable matter of interpretation. To say that one "is" an Asian American or a transvestite or a Democrat or a man or a Texan never means that one's self-image can be captured by any of these labels. It is common to feel both inside and outside these group identifications simultaneously. In part this is because each of these labels has meanings imposed by outsiders that a self-

${ }^{20}$ Quoted in Kenneth Gergen, The Saturated Self: Dilemmas of Identity in Contemporary Life 155 (Basic Books, 1991). 
identified group member might reject: being called a queer from someone in a passing car does not have the same meaning as the feeling of identification with Queer Nation. ${ }^{21}$

But there is no single group identity from an insider perspective either. Since everyone is a member of many groups, any particular group label falsifies to the extent it suggests a sameness within the group. A group identity has to be forged out of differences that divide the group; it never simply exists. Every group member recognizes the problem of uniting all Asian Americans or transvestites or Democrats or men or Texans behind any single cause. But the multiplicity of group identifications also allows some group members to dispute the legitimacy of others' claim to membership: to some Asian Americans, an American from Sri Lanka is not a "real" Asian American; to some Texans, an Asian American is not a "real" Texan; to some men, a transvestite is not a "real" man; to some Democrats, Paul Tsongas is not a "real" Democrat. As Barbara Johnson observes, "[d]ifference disliked is identity affirmed."22

This critique of the coherence of collective identity, often called "anti-essentialism," has been elaborated extensively in literature denying that there is a core identity to being black $^{23}$ or being

21

Quite often when we say "subject position" we reduce it to a kind of confessional attitudinizing. We say, "I'm white, I'm black, I'm a mulatto/a, I am male, I'm bourgeois." A subject position is not, in fact, a confessional self-description either in praise or in dis-praise. . . . It is because the position of the subject can be assigned ... [and] "assigned" means, I think, that it can and must become a sign; not for the person who speaks, but for the person who listens, not for the person who writes, who can say what she likes about who she is, but for the person who reads. When, in fact, the responsible reader reads the sign that is the subject position of the speaker or the writer, it becomes the sign, let us say, of an ethno-politics, of a psychosexual reality, of an institutional position, and this is not under the control of the person who speaks. She cannot diagnose herself; we are given over to our readers.

Gayatri Chakravorty Spivak, A Response to "The difference within: Feminism and critical theory," in Elizabeth Meese and Alice Parker, eds, The Difference Within: Feminism and Critical Theory 207, 208 (John Benjamins, 1989), as quoted in Barbara Johnson, The Alchemy of Style and Law, in Austin Sarat, ed, The Rhetoric of Law (forthcoming 1993). For a similar point, see Williams, Alchemy at 10 (cited in note 12).

22 Barbara Johnson, $A$ World of Difference 178 (Johns Hopkins, 1987).

${ }^{23}$ See, for example, Appiah, In My Father's House at 28-46, 173-80 (cited in note 12); Regina Austin, "The Black Community," Its Lawbreakers, and A Politics of Identification, 65 S Cal L Rev 1769 (1992); Kimberle Crenshaw, Demarginalizing the Intersection of Race and Sex, 1989 U Chi Legal F 139; Richard T. Ford, Urban Space and the Color Line: The Consequences of Demarcation and Disorientation in the Postmodern Metropolis, 9 Harv Blackletter J 117, 120-26 (1992); Harris, 42 Stan L Rev 581 (cited in note 12); bell hooks, Yearning at 15-31 (cited in note 12); Williams, Alchemy (cited in note 12). A fortiori, collective nouns like "Hispanics" and "Asian Americans"-nouns grouping people with a host of 
a woman ${ }^{24}$ or being gay. ${ }^{25}$ The argument applies equally to groups such as cities. Territorial boundaries circumscribe a very diverse group of people. For major American cities, this is obvious enough: race, ethnicity, class, politics, gender, sexual preference, and neighborhood, among other sources of identity, fracture the city in a multitude of ways. But suburbs are also not homogeneous. ${ }^{26} \mathrm{Al}$ though some city differences (such as class) may not exist in some suburbs, others plainly do. Concerns about politics, gender, sexual preference, and neighborhood-let alone the economy and the ozone layer-do not stop at the suburban border. Clearly, some suburban residents identify less with their neighbors than with people from the city who share their race or ethnicity or some other source of their identity. Other suburban residents are ambivalent about their locality: happy to have escaped the city and anxious to escape suburban boredom. Besides, most suburban residents have never even met each other. A suburb, like a city, is no more than an "imagined community": it consists of people who have only an image of their connection with each other. ${ }^{27}$ This im-

different origins and characteristics-do not refer to a core identity. See, for example, Yehudi O. Webster, The Racialization of America 118-19 (St. Martin's, 1992) ("The term Hispanics, then, settles uneasily within assessments of Hispanic appearance, nature of surname, country of origin, knowledge of Spanish, and self-identification."); Earl Shorris, Latinos: A Biography of the People 62-64 (Norton, 1992); Sucheng Chan, Asian Americans: An Interpretive History xvi (Twayne, 1991).

24 See, for example, Butler, Gender Trouble (cited in note 19); Judith Butler and Joan W. Scott, eds, Feminists Theorize the Political (Routledge, 1992); Drucilla Cornell, Beyond Accommodation: Ethical Feminism, Deconstruction and the Law (Routledge, 1991); Mary Joe Frug, Postmodern Legal Feminism (cited in note 12); Minow, Making All the Difference (cited in note 12); Moi, French Feminist Thought (cited in note 12); Elizabeth V. Spelman, Inessential Woman: Problems of Exclusion in Feminist Thought (Beacon, 1988). See generally The Essential Difference: Another Look at Essentialism, 1 differences (Summer 1989) (volume containing seven articles on this topic). See also Joan C. Williams, Dissolving the Sameness/Difference Debate: A Post-Modern Path Beyond Essentialism in Feminist and Critical Race Theory, 1991 Duke L J 296.

${ }^{28}$ See, for example, Dan Danielsen, Representing Identities: Legal Treatment of Pregnancy and Homosexuality, 26 New Eng L Rev 1453, 1504-05 (1992); David M. Halperin, One Hundred Years of Homosexuality (Routledge, 1990); Darrell Yates Rist, Are Homosexuals Born That Way?: Sex on the Brain, The Nation 424-29 (October 19, 1992); and Eve Kosofsky Sedgwick, Epistemology of the Closet (California, 1990). See generally Queer Theory: Lesbian and Gay Sexualities, 3 differences (Summer 1991) (volume containing eight articles on this topic). See also John L. Peterson, Black Men and Their Same-Sex Desires and Behaviors, in Gilbert Herdt, ed, Gay Culture in America: Essays From the Field 147, 153-54 (Beacon, 1992) (distinguishing "black gays" and "gay blacks").

${ }^{28}$ See, for example, Mark Baldassare, Trouble in Paradise: The Suburban Transformation in America 1-45 (Columbia, 1986). See also notes 257-64 and accompanying text.

${ }^{27}$ Benedict Anderson, Imagined Communities: Reflections on the Origin and Spread of Nationalism 15 (Verso, 1983) (defining a nation). 
age is a "fiction": it "is not something given, it is something added and invented and projected behind what there is." ${ }^{\prime 28}$

\section{B. The Centered Subject in Local Government Law}

Nevertheless, American law defines cities as centered subjects. Richard Briffault's mammoth article surveying the field calls this conception of local subjectivity "localism." He defines localism as "a belief that land-use regulation, schools, and tax policy ought to be controlled locally, with the interests of local residents as the exclusive desideratum of local decision makers." ${ }^{29}$ Localism, he adds:

reifies local borders, using invisible municipal boundary lines to delimit the range of local concern and the proper subjects of local compassion and treating the creation and maintenance of local borders as a basic right. . . . Local borders, once created, reinforce local identification, become a focus of sentiment and symbolism and create a powerful legal bulwark for the preservation of local interests. ${ }^{30}$

This definition of localism contains all the ingredients of a centered subject: boundary lines separate one subject from another, each subject looks only within to determine its interests, and "preservation of local interests" is a meaningful goal. Localism treats each city as an individual entity, with no inter-city relationships considered necessary. The only relevant governmental decisionmakers are the cities and the state. Because the state has power to regulate the undesirable external effects of city actionslike those of autonomous individuals-cities are allowed to act, whenever permitted by state law, as if they had no neighbors. ${ }^{31}$

Professor Briffault contends that localism has empowered suburbs in America while it has disadvantaged cities. Relying on the examples of exclusionary zoning, ${ }^{32}$ school financing, ${ }^{33}$ and protection against annexation, ${ }^{34}$ he asserts that courts and legislatures

${ }^{28}$ Nietzsche, Will to Power $\S 370$ at $199, \S 481$ at 267 (cited in note 15).

29 Briffault, 90 Colum L Rev at 444 (cited in note 3).

so Id at 444-45.

${ }^{31}$ The classic way of limiting the external effects of city actions has been enabling them to exercise home rule only on purely local (or purely municipal) matters and requiring specific state delegation of power for any other city activity. See id at 8-14; Gerald E. Frug, Local Government Law 56-127 (West, 1988).

32 Briffault, 90 Colum L Rev at 39-58, 101-09, 366-74 (cited in note 3).

ss Id at 18-39, 99-101.

34 Id at 77-81, 109-11. 
have protected suburbs', but not cities', ability to shape their own social and economic development by defining local interests narrowly. Courts and legislatures, he argues, have made "[ $t]$ he central function of local government" the protection of "the home and family-enabling residents to raise their children in 'decent' surroundings, servicing home and family needs and insulating home and family from undesirable changes in the surrounding area." 35 This focus, he says, has led "to an association of the locality with individual autonomy." ${ }^{\text {s6 }}$

Three cases illustrate Professor Briffault's concept of localism. In Village of Belle Terre $v$ Boraas, ${ }^{37}$ the United States Supreme Court rejected a challenge to a local zoning ordinance that prohibited a group of unrelated university students from sharing a house in the village. Justice Douglas, writing for the Court, asserted that guidelines providing "[a] quiet place where yards are wide, people few, and motor vehicles restricted" are legitimate "in a land-use project addressed to family needs." 38 Rejecting the contention that the ordinance injured fundamental rights, Justice Douglas held instead that "the police power ... is ample to lay out zones where family values, youth values, and the blessings of quiet seclusion and clean air make the area a sanctuary for people." 39 In Buse $v$ Smith, ${ }^{40}$ the Supreme Court of Wisconsin declared invalid a school financing plan that equalized revenues by reallocating money from property-rich districts to property-poor districts. Asserting that taxes are legitimate only for the uses of the government levying them, the court held that it violated the state constitution to take money raised in one district and spend it in another. ${ }^{41}$ Finally, in Town of Lockport $v$ Citizens for Community Action, ${ }^{42}$ the United States Supreme Court deemed it constitutional in annexation or consolidation decisions to have a dual ballot box system-one that required a majority of city and of non-city voters, counted separately, to approve the measure-even though such a system frustrated the will of a majority of the area taken as a whole. States,

ss Id at 382 .

so Id at 444 .

37 416 US 1 (1974), discussed in Briffault, 90 Colum L Rev at 383 (cited in note 3).

${ }^{38}$ Belle Terre, 416 US at 9.

${ }^{39}$ Id.

40 74 Wis 2d 550, 247 NW2d 141 (1976), discussed in Briffault, 90 Colum L Rev at 2930 (cited in note 3 ).

4247 NW2d at 152-55.

4240 US 259, 271-73 (1977), discussed in Briffault, 90 Colum L Rev at 109 (cited in note 3$)$. 
the Court reasoned, can legitimately recognize "the discrete interests that such local governmental units may have qua units."4s

Joan Williams argues that this preference for suburban rather than urban interests protects not home and family but property values. ${ }^{44}$ The United States Supreme Court's cases dealing with zoning and school financing, she contends, have "served to protect private property (the taxpayer's wallet or the suburban enclave) against redistributive intrusions . . . ."45 She could easily have said the same thing about protection against annexation. Indeed, both Professor Briffault and Professor Williams could offer their theories to explain a wide variety of cases that defend suburban localism. Either theory might explain, for example, the United States Supreme Court's rejection in Milliken $v$ Bradley ${ }^{48}$ of an area-wide school desegregation plan, thereby immunizing the suburbs from having to participate in the effort to desegregate Detroit's schools.

Professor Williams's emphasis on property has the added advantage, however, of being equally applicable to cases that defend local autonomy without making a city/suburb distinction. Many recent Supreme Court decisions suggest that cities can best empower themselves by acting just like property owners. In National League of Cities $v$ Usery, ${ }^{47}$ for example, the Supreme Court held that Congress did not have the power to displace localities' "freedom to structure integral operations in areas of traditional governmental functions." 48 One "undoubted" example of such a function, the Court reasoned, was the ability to determine the wages and

43430 US at 269.

4" Joan C. Williams, The Constitutional Vulnerability of American Local Government: The Politics of City Status in American Law, 1986 Wis L Rev 83, 105-20. For an extended sociological analysis of cities in terms of urban property relations, see John R. Logan and Harvey L. Molotch, Urban Fortunes: The Political Economy of Place (California, 1987).

${ }_{13}$ Williams, 1986 Wis L Rev at 119 (cited in note 44). From this perspective, exclusionary zoning is no more than the extension to localities of the traditional right of property owners to exclude outsiders. See Frug, Local Government Law at 485 (cited in note 31). And cases like Salyer Land Co. v Tulare Lake Basin Water Storage District, 410 US 719 (1973), which upheld a statute that limited to property owners the ability to vote for directors of a water district, are simply overt examples of the policy local government generally implements. See Williams, 1986 Wis L Rev at 117.

16 418 US 717, 752-53 (1974), discussed in Williams, 1986 Wis L Rev at 110-11 (cited in note 44), and in Briffault, 90 Colum L Rev at 94-96 (cited in note 3).

47426 US 833 (1976). National League of Cities has, of course, been overruled by Garcia v San Antonio Metropolitan Transit Authority, 469 US 528, 546-47 (1985), but the even more recent case of New York v United States, 112 S Ct 2408, 2427-29 (1992), suggests that aspects of National League of Cities might someday be resurrected. Joan Williams discusses National League of Cities in 1986 Wis L Rev at 113 (cited in note 44).

48 US at 852. 
hours of their employees ${ }^{48}$ - a function that can with equal justification be viewed as an "undoubted" example of the rights of property owners. Similarly, in White $v$ Massachusetts Council of Construction Employers, ${ }^{\text {so }}$ the Supreme Court held that Boston's policy of requiring its contractors to hire city residents was not invalid under the dormant Commerce Clause because the city was acting as a "market participant" rather than a "market regulator." The typical "market participant," of course, is a property owner. In a later case dealing with facts like those in White, the Court rejected the market participant/market regulator distinction for the Privileges and Immunities Clause. ${ }^{51}$ Nevertheless, it suggested that deference to local decisionmaking even under that Clause would be particularly appropriate when a locality "is merely setting conditions on the expenditure of funds it controls"s2 - another reference to traditional actions of property owners. And only last term, in a case limiting freedom of speech at airports, the Court held that " $[w]$ here the government is acting as a proprietor, . . . rather than acting as lawmaker with the power to regulate or license, its action will not be subjected to the heightened review to which its actions as a lawmaker may be subject."s3

In addition to "home and family" and "property," a third possibility could explain the judicial and legislative defense of localism: the concept of community. Consider, for example, Chief Justice Burger's defense of a suburb's decision to ban nude dancing:

The residents of this small enclave chose to maintain their town as a placid, "bedroom" community of a few thousand people. To that end, they passed an admittedly broad regulation prohibiting certain forms of entertainment. Because I believe that a community of people are-within limits-masters of their own environment, I would hold that, as applied, the ordinance is valid. . . . Citizens should be free to choose to shape their community so that it embodies their conception of the "decent life." This will sometimes mean deciding that cer-

\footnotetext{
48 Id at 845.

so 460 US 204, 206-08, 214-15 (1983).

${ }^{51}$ United Bldg. \& Constr. Trades Council of Camden County $v$ Mayor and Council, 465 US 208, 219-20 (1984).

${ }^{32}$ Id at 223. For an analysis of White, United Bldg. \& Constr., and National League of Cities, see Gerald E. Frug, Property and Power: Hartog on the Legal History of New York City, 1984 Am Bar Found Res J 673, 681-87.

${ }^{83}$ International Soc. for Krishna Consciousness, Inc. v Lee, 112 S Ct 2701, 2705 (1992).
} 
tain forms of activity-factories, gas stations, sports stadia, bookstores, and surely live nude shows-will not be allowed. ${ }^{\mathbf{5 4}}$

This invocation of community relies on the romantic, touchy-feely image commonly associated with the term. It evokes the idealized feeling of belongingness, oneness, solidarity, and affective connection imagined to have existed in a traditional, face-to-face village-in sociological terms, Gemeinschaft (community) rather than Gesellschaft (society). ${ }^{85}$ Like the invocation of home and family, the Gemeinschaft image is reserved for the suburbs. ${ }^{56}$ It is invoked in the school financing ${ }^{57}$ and annexation ${ }^{58}$ contexts, as well as in efforts to control local character by zoning out pornography. ${ }^{59}$ As Laurence Tribe suggests, this notion of community provides another explanation for the result in Village of Belle Terre $v$ Boraas. ${ }^{\text {00 }}$

All three justifications for the defense of localism-home and family, property, and community-have one thing in common: they all are based on the notion of the centered subject. Each explanation is presented as a coherent way to locate the subjectivity of individual suburban residents. Home and family, property, and community are values that individuals can call their own. Indeed, they are values so important that they can unite all individuals

s4 Schad v Mount Ephraim, 452 US 61, 85, 87 (1981) (Burger dissenting). See generally Robert Chesler, Imagery of Community, Ideology of Authority: The Moral Reasoning of Chief Justice Burger, 18 Harv CR-CL L Rev 457, 465-66 (1983) (criticizing Chief Justice Burger for using the concept of community to overide the rights of the minorities).

ss Ferdinand Tönnies, Community and Society (Gemeinschaft und Gesellschaft) (Transaction, 1988). Compare Benhabib, Situating the Self at 76-82 (cited in note 12) (contrasting two versions of community).

se For an example of the use of such an image, see Hadley Arkes, The Philosopher in the City: The Moral Dimension of Urban Politics 320-26 (Princeton, 1981).

87 "Unless a local community, through its school board, has some control over the purse, there can be little real feeling in the community that the schools are in fact local schools ...." San Antonio Independent School District v Rodriguez, 411 US 1, 53 n 109 (1973) (citation omitted).

ss "[T]he fact that the residents of the annexing city and the residents of the area to be annexed formed sufficiently different constituencies with sufficiently different interests could be readily perceived. The fact of impending union alone would not so merge them into one community of interest as constitutionally to require that their votes be aggregated in any referendum to approve annexation." Town of Lockport $v$ Citizens for Community Action, 430 US 259, 271 (1977).

39 The city of Renton "has sought to make some areas available for adult theaters and their patrons, while at the same time preserving the quality of life in the community at large by preventing those theaters from locating in other areas. This, after all, is the essence of zoning." Renton $v$ Playtime Theatres, Inc., 475 US 41, 54 (1986). See generally Laurence H. Tribe, American Constitutional Law \$ 12-16 at 908-10 (Foundation, 2d ed, 1988).

${ }^{\circ}$ Tribe, American Constitutional Law $\$ 15-17$ at 1400-09. See text accompanying notes 37-39 for a description of the case. 
within a locality, thereby making it appropriate to think of them as a single, unified group. These values give content to the "imagined community" of the suburb, enabling it to have a legal personality, an identity, a unicity.

References to these values in local government law, in sum, suppress the deconstructive critique to which each has been subjected elsewhere in the legal system. The blissful notion of home and family omits any reference to divorce, child-abuse, work/family conflicts, . violence against women, and the like-a mainstay of the study of family law. ${ }^{61}$ The concept of property invoked is the pre-modern notion of absolute dominion over external objects ("thing-ownership"), ${ }^{62}$ which the modern "bundle-of-rights" conception has so fractured that many, like Thomas Grey, speak of "the disintegration of property." presses not only conflicts generated by issues of race, gender, and the like, but also those generated by individualism and instrumentalism - in other words, the entire modern critique of unity (summarized in the idea of Gesellschaft) ${ }^{64}$ Of course, combining all three idealized values produces a familiar centered subject, one ably captured by Norman Rockwell in the 1950s. But local government law is one of the few places in the legal system in which this picture is still presented as truth. ${ }^{65}$

So far, my discussion of the centered subject in local government law has focused on cases in which courts or legislatures have given power to localities-particularly suburbs. Much of local government law, however, consists of doctrines designed to limit local power. These doctrines rely on a different notion of the centered subject, not the "localism" associated with the autonomous individual but the idea of sovereignty associated with the state. The most common image associated with the fear of local sovereignty is that of tyranny of the majority, epitomized in the modern imagination by Brown $v$ Board of Education.$^{68}$ Because local governments,

${ }^{B 1}$ See, for example, Mary Joe Frug, Women and the Law 308-553 (Foundation, 1992).

62 Thomas C. Grey, The Disintegration of Property, in J. Roland Pennock and John W. Chapman, eds, Property: Nomos XXII 69, 73 (New York, 1980); Duncan Kennedy, The Structure of Blackstone's Commentaries, 28 Buff L Rev 205, 318-20 (1979).

${ }^{63}$ Grey, The Disintegration of Property at 73-74 (cited in note 62). See also Tribe, American Constitutional Law $\S 9-7$ at 607 (cited in note 59) ("The Problematic Nature of Property").

ot See, for example, Iris Marion Young, The Ideal of Community and the Politics of Difference, in Linda J. Nicholson, ed, Feminism/Postmodernism 300 (Routledge, 1990). See also Briffault, 90 Colum $\mathrm{L}$ Rev at $412-15$ (cited in note 3 ).

os But not the only one. See, for example, Bowers v Hardwick, 478 US 186 (1986).

c6 347 US 483 (1954). 
like states, threaten the rights of minorities, the Fourteenth Amendment limits their ability to deal with issues of race, ${ }^{67}$ speech, ${ }^{68}$ religion, ${ }^{69}$ and property. ${ }^{70}$ Indeed, in an American tradition that dates back to Federalist 10, cities are seen as even more threatening to minorities than states because they are smaller. ${ }^{71}$ Thus, unlike states, they are absolutely liable under $\S 1983$ for violating their citizens' rights. ${ }^{72}$ And they have been subjected to virtually unlimited control by state governments; cities are treated under local government law as mere "creatures of the state."73

The doctrines that curb local governmental authority invoke the protection of home and family, property, and community as reasons for restraining local power, not as reasons for sustaining it. A city's land-use laws can jeopardize people's control over their own homes. ${ }^{74}$ Its zoning laws can prohibit members of the same family from living together. ${ }^{75}$ Its regulatory activity can threaten to redistribute wealth ${ }^{26}$ and even undermine the national economy by favoring its own residents over the interests of national commerce. ${ }^{77}$ Its condemnation of land can destroy an intact neighborhood community, ${ }^{78}$ and its regulation of campaign financing can undermine "the practice of persons sharing common views banding together to achieve a common end."79 Although these dangers can arise in either cities or suburbs, they are more commonly associated with cities. Cities are often thought of as smaller versions of states and of the federal government-as just another layer of government-while suburbs have been more successful in associating

${ }^{67}$ See, for example, City of Richmond $v$ J.A. Croson Co., 488 US 469, 486-508 (1989).

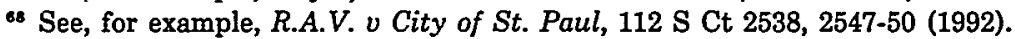

* See, for example, Lee v Weisman, $112 \mathrm{~S} \mathrm{Ct} 2649$, 2655-61 (1992).

${ }^{70}$ See, for example, First English Evangelical Lutheran Church $v$ Los Angeles County, 482 US 304, 314-22 (1987).

${ }^{71}$ Federalist 10 (Madison) in J.R. Pole, American Constitution at 150 (cited in note 1); Croson, 488 US at 523-24 (Scalia concurring in the judgment).

7242 USC \& 1983 (1988); Monell v Department of Social Services, 436 US 658, 690 (1978); Owen $v$ City of Independence, 445 US 622, 646-48 (1980); Will v Michigan Department of State Police, 491 US 58, 70 (1989).

${ }^{73}$ See Frug, 93 Harv L Rev at 1062-67 (cited in note 11).

${ }^{74}$ See, for example, First Lutheran Church, 482 US at 306-07 (county ordinance prohibited persons from constructing, reconstructing, or enlarging any building or structure in a flood protection area).

${ }_{75}$ Moore v City of East Cleveland, 431 US 494, 495-96 (1977).

76 See Williams, 1986 Wis L Rev at 119 (cited in note 44).

${ }_{77}$ Dean Milk Co. v Madison, 340 US 349, 350-53 (1951); City of Oakland v Oakland Raiders, 174 Cal App 3d 414, 220 Cal Rptr 153, 158 (1985).

${ }_{78}$ Poletown Neighborhood Council v City of Detroit, 410 Mich 616, 304 NW2d 455, 457 (1981).

70 Citizens Against Rent Control v City of Berkeley, 454 US 290, 294 (1981). 
themselves with the protection, rather than the regulation, of the private sphere of home and family, property, and community. Moreover, to the extent that cities are envisioned as populated by the poor and by racial and ethnic minorities, they are seen more readily than are middle-class suburbs as vehicles for the irrational or greedy or merely self-interested appetite of the masses. Fear of the tyranny of the majority may have taken the place of the ancient fear of the King, ${ }^{80}$ but collective tyranny is still treated, like the King's tyranny, as if it were the exercise of the passions and power of an uncontrollable and unpredictable sovereign subject. "What is a majority, in its collective capacity," Tocqueville asks, "if not an individual with opinions, and usually with interests, contrary to those of another individual, called the minority?"\$1

Sovereignty, however, is not the only version of the centered subject invoked to limit local government power. Sometimes cities are envisioned, and regulated, like property owners. Both property owners and cities can be defined in terms of territory, organized to advance "parochial interests," and be understood as having a concrete self-interest to promote. Consider, for example, the reason advanced by the Supreme Court in Community Communications Co. $v$ Boulder $^{82}$ for denying cities the exemption from the antitrust laws that the states enjoy under Parker $v$ Brown ${ }^{83}$ :

Cities are not themselves sovereign; they do not receive all the federal deference of the States that create them. Parker's limitation of the exemption to "official action directed by a state," is consistent with the fact that the States' subdivisions generally have not been treated as equivalents of the States themselves. In light of the serious economic dislocation which could result if cities were free to place their own parochial interests above the Nation's economic goals reflected in the anti-trust laws, we are especially unwilling to presume that Congress intended to exclude anticompetitive municipal action from their reach..$^{84}$

This reasoning imagines cities to be more like self-interested autonomous individuals than like states. As Justice Rehnquist observed in dissent, such a connection was necessary before cities,

${ }^{80}$ Foucault, Power/Knowledge at 94 (cited in note 18).

${ }^{81}$ Alexis de Tocqueville, Democracy in America 251 (Doubleday, 1969).

82455 US 40 (1982).

8s 317 US 341 (1943).

at Community Communications, 455 US at 50-51, quoting City of Lafayette $v$ Louisiana Power \& Light Co., 435 US 389, 412-13 (1978). 
unlike states, could be seen as engaging in the kind of anti-competitive activity that the antitrust laws were designed to prevent..$^{85}$ Other cases similarly connect the dangers involved in allowing cities and property owners "to place their own parochial interests" above the public interest. In Matthews $v$ Bay Head Improvement Association, ${ }^{86}$ for example, the Supreme Court of New Jersey held that a property owners' association, like a city, could not exclude non-residents from equal access to the local beach. The court reasoned that the impact on non-residents was identical regardless of whether the non-residents were excluded by the association or by a municipality. ${ }^{87}$

The fear of local government power, whether understood in terms of sovereignty or property, thus shares with the celebration of localism the identification of decentralized power with a centered subject. In an earlier article, I argued that the fear of local power exceeded the celebration of its virtues and that local government law should allocate more power to cities. ${ }^{88}$ Professor Briffault has criticized my thesis, arguing correctly that my analysis understated the amount of power that suburbs currently exercise in America. ${ }^{89}$ But Professor Briffault's article is itself an extended argument for greater centralization. He rejects suburban power, and the ideology of localism on which it is based, because it "perpetuates interpersonal as well as interlocal economic and social inequalities." ${ }^{90} \mathrm{He}$ calls instead for an increase in the power of states. ${ }^{91}$ Professor Briffault would like to preserve some role for localities, but both cities and suburbs would become even more powerless if his proposal were adopted.

I do not think that the solution to the problem of social and economic inequality lies in the rejection of decentralization. As I have argued elsewhere at length, I think decentralization is worth defending: states could never engender the kind of democratic participation in public affairs that is possible on a local basis. ${ }^{92} \mathrm{Al}-$ though Professor Briffault has properly identified the problems

${ }^{85}$ Id at 69-71 (Rehnquist dissenting).

38 95 NJ 306, 471 A2d 355 (1984).

87 Id at 365-69.

88 Frug, 93 Harv L Rev at 1069-70 (cited in note 11).

so See Briffault, 90 Colum L Rev at 346-56 (cited in note 3).

${ }^{\circ}$ Id at 438.

IId at 447-54.

92 See Frug, 93 Harv L Rev at 1067-73 (cited in note 11); Frug, 40 U Toronto L J at 574-79 (cited in note 11); Gerald Frug, Empowering Cities in a Federal System, 19 Urban L 553 (1987). 
with current judicial and legislative deference to suburban self-interest, he does not confront the equally serious problems engendered by cities' inability to be self-governing. Yet the problems of suburban self-interest and of cities' incapacity to be self-governing have the same source: the terms "self-interest" and "self-governing" both rely on the same concept of the self. To decentralize power, we need to decenter this centered subject.

\section{Decentering the Subject in Local Government Law}

In American law, cities are creatures of the state: they have only the power states give them, power that states can modify or withdraw at will. ${ }^{93}$ In the words of the treatise-writer, John Dillon, a city is subservient to the state "which breathed into it the breath of life." with any subjectivity they please. Even people who cannot help thinking of individuals or the nation-state as having a "natural" subjectivity must recognize that there is nothing natural about the subjectivity currently attributed to localities. Local government law, having endowed localities with the subjectivity of the centered subject, can just as readily decenter that subjectivity.

The problem is to figure out how to do that. It would be paradoxical for me to try now to nail down exactly what a decentered subjectivity for a locality would look like. Doing so would entail giving the decentered subject a specific content-in other words, it would require finding a center for the decentered subject. The literature about the decentered subject does more than merely reject such a notion of a stable identity for the self. It provides many different notions about what a decentered self is. I suggest below two different ideas for a new subjectivity for localities in local government law: the situated self and the postmodern self. But these ideas are my own creations, based loosely on a literature with an astonishing variety of ideas about decentered subjectivity. ${ }^{95}$ Countless other candidates for local government subjectivity can be imagined.

\footnotetext{
${ }^{93}$ See Frug, 93 Harv L Rev at 1062-67 (cited in note 11); Hunter v Pittsburgh, 207 US 161, 178-79 (1907).

24 John F. Dillon, Treatise on the Law of Municipal Corporations $\S 39$ at $83 \mathrm{n} 1$ (James Cockcroft, 1872).

${ }^{95}$ See note 12. See also Jacques Derrida, "Eating Well," or the Calculation of the Subject: An Interview with Jacques Derrida, in Eduardo Cadava, Peter Connor, and Jean-Luc Nancy, eds, Who Comes After the Subject? 96, 102 (Routledge, 1991) (suggesting that the critique of the subject has addressed multiple targets because there is no single idea of The Subject to attack).
} 
This multiplicity of possibilities for a city's subjectivity is not a problem that needs to be overcome; we do not need one test for cities' subjectivity. Indeed, I do not think that legal scholarship-or courts-could ever find such a single standard, let alone one that others could simply implement. Of necessity, readers will interpret any notion of subjectivity that I propose, like any legal doctrine, in a variety of ways. Some readers may find my two ideas to be indistinguishable; others may find them to be totally inconsistent with each other; still others may prefer different ideas based on some other version of the decentered subject. In this Article, I hope to stimulate the production of these multiple readings, as well as the production of concrete suggestions about how to redefine what local governments are and what they can do. I advance below what I consider utopian proposals for doctrinal and institutional change: they are utopian because they represent modifications in the current structure of local government law so minor that many readers will consider them insufficient to transform our cities and suburbs and, at the same time, so radical that they will strike other readers as inconceivable. ${ }^{96} \mathrm{My}$ aim is to help reframe local government law not by offering classic policy proposals-I draft no statutes and offer no tests for courts to apply-but by encouraging others to react against my suggestions and thereby to generate their own ideas about how to revise the current entitlements of local governments. ${ }^{97}$

\section{The Situated Subject}

One way of decentering the subjectivity of localities would be to build on the literature that emphasizes that the self is formed only through a relationship with others. As Kenneth Gergen puts it, "it is not individual 'I's who create relationships, but relationships that create the sense of ' $I$ '."'98 This insight has stimulated a wide variety of communitarians, civic republicans, and feminists, among others. It would be impossible here to survey this extensive literature or even to summarize the work of a single writer to whom I am referring. I do think, however, that it is important to

96 Karl Mannheim, Ideology and Utopia 173-84 (Harcourt, Brace, 1946).

97 Compare Roland Barthes, Image, Music, Text at 163 (cited in note 12) ("We know that today post-serial music has radically altered the role of the 'interpreter', who is called on to be in some sort the co-author of the score, completing it rather than giving it 'expression'. The Text is very much a score of this new kind: it asks of the reader a practical collaboration.").

"s Gergen, The Saturated Self at 157 (cited in note 20). 
take a brief look at the kinds of claims made by people who write in these traditions before turning to the changes I propose in local government law doctrine.

\section{A. A Glimpse at the Literature}

Michael Sandel, Charles Taylor, and Michael Walzer are examples of those often labeled communitarians. ${ }^{99}$ Sandel describes what he calls a situated or "constitutive conception" of the self.

[T]o say that the members of a society are bound by a sense of community is not simply to say that a great many of them profess communitarian sentiments and pursue communitarian aims, but rather that they conceive their identity-the subject and not just the object of their feelings and aspirations-as defined to some extent by the community of which they are a part. For them, community describes not just what they have as fellow citizens but also what they are, not a relationship they choose (as in a voluntary association) but an attachment they discover, not merely an attribute but a constituent of their identity. ${ }^{100}$

In the same vein, Charles Taylor asserts that "our identity is always partly defined in conversation with others or through the common understanding which underlies the practices of our society." "Taylor argues that the "autonomous individual" himself is a social construct: "the free individual of the West is only what he is by virtue of the whole society and civilization which brought him to be and which nourishes him." ${ }^{102}$ If so, the autonomous individual has to be interested in others, not as a matter of sentimentality or altruism but as a matter of self-interest. ${ }^{103}$ "[S]ince the free individual can only maintain his identity within a society/culture of a certain kind, he has to be concerned about the shape of this soci-

\footnotetext{
99 None of these labels (here or elsewhere in this article) should be taken very seriously. The same people are often grouped in different ways. Seyla Benhabib labels the three people mentioned here-along with Alasdair MacIntyre-communitarians; Stephen Gardbaum calls them communitarians as well, but he considers Sandel and MacIntrye "civic republicans" and Walzer a "liberal." Compare Benhabib, Situating the Self at 2 (cited in note 12), with Stephen Gardbaum, Law, Politics and the Claims of Community, 90 Mich L Rev 685, 697-701, 723-30 (1992).

${ }^{100}$ Sandel, Liberalism and the Limits of Justice at 150 (cited in note 4).

101 Taylor, Philosophy and the Human Sciences at 209 (cited in note 12).

102 Id at 206. See also id at 205-06; Walzer, 18 Political Theory at 15 (cited in note 12).

${ }^{103}$ See, for example, Charles Taylor, Cross-Purposes: The Liberal-Communitarian Debate, in Nancy L. Rosenblum, ed, Liberalism and the Moral Life 159, 160-63 (Harvard, 1989) (commenting on Sandel).
} 
ety/culture as a whole."104 Indeed, Michael Walzer contends, everyone-liberal or communitarian-has to recognize the collective contribution to the constitution of the self. What people disagree about, in his view, "is not the constitution of the self but the connection of constituted selves, the pattern of social relations."105

As Walzer suggests, the recognition that the self is a product of human relationships does not endow the self with any particular identity. ${ }^{108}$ Quite the contrary: the multiple possibilities for human relationship produce multiple possibilities for the self. Liberalism, according to Walzer, is a theory of relationship "which has voluntary association at its center and which understands voluntariness as the right of rupture or withdrawal.".107 Civic republicanism, by contrast, seeks to promote a different kind of human relationship and, thereby, to encourage a different kind of self-development. ${ }^{108}$ Frank Michelman describes this conception in terms of dialogue. The republican concept of the subject, he says,

contemplates ... a self whose identity and freedom consist, in part, in its capacity for reflexively critical reconsideration of the ends and commitments that it already has and that make it who it is. Such a self necessarily obtains its self-critical resources from, and tests its current understandings against, understandings from beyond its own pre-critical life and experience, which is to say communicatively, by reaching for the perspectives of other and different persons. ${ }^{109}$

For Michelman and others who write in the republican tradition, this conception of the self transforms the meaning of the idea that "we are free only insofar as we are self-governing." 110 The term "self-government" becomes a collective, not an individual, activity: "self-cognition and ensuing self-legislation must . . . be so-

104 Taylor, Philosophy and the Human Sciences at 207 (cited in note 12).

105 Walzer, 18 Political Theory at 21 (cited in note 12). See also Michael Walzer, Three Paths in Moral Philosophy, in Interpretation and Social Criticism 1, 3-32 (Harvard, 1987).

${ }_{108}$ See generally, Gardbaum, 90 Mich L Rev 685 (cited in note 99).

107 Walzer, 18 Political Theory at 21 (cited in note 12).

${ }^{108}$ For references to the civic republican literature, see, for example, Mark Seidenfeld, A Civic Republican Justification for the Bureaucratic State, 105 Harv L Rev 1511, 1514 n 10 (1992); Richard H. Fallon, Jr., What is Republicanism, and Is It Worth Reviving?, 102 Harv L Rev 1695, 1695 nn 2, 4 (1989); Frank I. Michelman, Law's Republic, 97 Yale L J 1493, 1494-95 nn 3-5 (1988).

109 Michelman, 97 Yale L J at 1528. See also Frank Michelman, Private Personal But Not Split: Radin Versus Rorty, 63 S Cal L Rev 1783, 1788-90 (1990); Frank I. Michelman, The Supreme Court, 1985 Term, Forward: Traces of Self-Government, 100 Harv L Rev 4, 26-33 (1986).

${ }_{110}$ Michelman, 100 Harv L Rev at 26 (cited in note 109). 
cially situated; norms must be formed through public dialogue and expressed as public law."111 Self-government, in other words, is the work of politics. "In the strongest version. of republicanism," Michelman says, "[p]olitical engagement is considered a positive human good because the self is understood as partially constituted by, or as coming to itself through, such engagement."112 Michelman quotes Hannah Pitkin: "Only in public life can we jointly, as a community, exercise the human capacity to 'think what we are doing,' and take charge of the history in which we are all constantly engaged by drift and inadvertence."113 Although Michelman does not embrace Pitkin's strong claim for the importance of politics, he, like others, defines republicanism in terms of the central importance of citizenship to human flourishing. ${ }^{114}$

Other writers do not accept this republican emphasis on-or definition of-politics. For example, although Roberto Unger defines the self in terms of relationship, ${ }^{115}$ his focus is on people's emotional connection with each other-their "experience of mutual longing"116 - together with their skepticism that any "particular framework of society and culture can give full expression to the opportunities of practical or passionate connection."117 This combined emphasis on personal encounters and cultural skepticism, which he calls the "Christian-romantic tradition," 118 has led Unger to investigate the paradoxes of empowerment: how can we connect with others on whom we so depend yet who make us so vulnerable? ${ }^{119}$ And how can we break out of the social and cultural con-

11 Id at 27. See id at 26-37; Michelman, 97 Yale L J at 1503-05 (cited in note 108); Cass R. Sunstein, Beyond the Republican Revival, 97 Yale L J 1539, 1548 (1988) ("collective selfdetermination").

122 Michelman, 97 Yale L J at 1503 (cited in note 108).

113 Id at 1504, quoting Hannah Fenichel Pitkin, Justice: On Relating Private and Public, 9 Political Theory 327, 344 (1981). See also J.G.A. Pocock, Virtues, Rights, and Manners: A Model for Historians of Political Thought, 9 Political Theory, 353, 355 (1981) ("classical republicanism ... entails the affirmation that homo is naturally a citizen and most fully himself when living in vivere civile").

114 Michelman, 97 Yale L J at 1504 (cited in note 108). See also Sunstein, 97 Yale L J at 1555-58 (cited in note 111); Fallon, 102 Harv L Rev at 1697 (cited in note 108).

110 "[T] our relations .... If one could imagine a situation in which no one treated a person or had ever treated him as a human being with a self, then in that situation he would have no self." Roberto Mangabeira Unger, Knowledge and Politics 216 (Free Press, 1975). 1984).

${ }^{116}$ Roberto Mangabeira Unger, Passion: An Essay on Personality 22 (Free Press,

117 Id at 37.

118 Id at 24.

11 Unger, Knowledge and Politics at 215 (cited in note 115). See also Unger, Passion at 20-22, 71-76 (cited in note 116). For an exploration of the differences between Unger's anal- 
texts that both define us as people and yet confine our ability for practical, passionate, and cognitive empowerment? In a series of books, Unger has explored these questions of personal and social connection in a wide variety of contexts: the nature of human passions, the organization of work, the structure of the economy, and the future of social theory, to name but a few. ${ }^{120}$ "To satisfy our longing for acceptance and recognition, to be intimately assured that we have a place in the world, and to be freed by this assurance for a life of action and encounter," Unger writes, "we must open ourselves to personal attachments and communal engagements whose terms we cannot predefine and whose course we cannot control."121 For Unger, personal and social transformation thus requires an understanding and revision of contexts considerably broader than the political sphere as the republican tradition defines it.

A number of strands of feminism also embrace a version of the situated self. No doubt the most famous example is Carol Gilligan's In a Different Voice. ${ }^{\mathbf{1 2 2}}$ Writing about theories of moral development, Gilligan draws a contrast "between a self defined through separation and a self delineated through connection, between a self measured against an abstract ideal of perfection and a self assessed through particular activities of care."123 For Gilligan, "[t] he ideal of care is . . . an activity of relationship, of seeing and responding to need, taking care of the world by sustaining the web of connection so that no one is left alone."124 Defining the link between this notion of care and gender-indeed, defining Gilligan's own link between the two-is, to put it mildly, a matter of considerable controversy. ${ }^{125}$ But Gilligan's book, at the very least, insists that a relationship-centered version of the self is an alternative to the traditional individualist conception of the highest form of moral development. "My own work," she writes, "indicates that the inclusion of women's experience brings to developmental un-

yses in Knowledge and Politics and Passion, see Cornell, $133 \mathrm{U} \mathrm{Pa} \mathrm{L} \mathrm{Rev} \mathrm{at} \mathrm{327-58} \mathrm{(cited} \mathrm{in}$ note 12).

120 See Roberto Mangabeira Unger, Politics: $A$ Work in Constructive Social Theory (Cambridge, 1987); Roberto Mangabeira Unger, The Critical Legal Studies Movement (Harvard, 1986); Unger, Passion (cited in note 116); Unger, Knowledge and Politics (cited in note 115).

121 Unger, Passion at 20 (cited in note 116).

122 Carol Gilligan, In a Different Voice (Harvard, 1982).

123 Id at 35 .

124 Id at 62.

${ }^{125}$ See, for example, Mary Joe Frug, Postmodern Legal Feminism at 30-49 (cited in note 12); Benhabib, Situating the Self at 178-98 (cited in note 12). 
derstanding a new perspective on relationships that changes the basic constructs of interpretation. The concept of identity expands to include the experience of interconnection."126

Finally-to offer one last example-Martha Minow has argued that we should not consider legal reasoning the product of a centered subject, let alone the product of no subject at all. She insists that there is no such thing as impartiality: "[i]mpartiality is the guise partiality takes to seal bias against exposure."127 But, she continues, recognizing one's own partiality is not enough. It allows people either to ignore the experience of others or to appropriate others' experience into their own understanding of the world. We must do more-we must learn to "take the perspective of another." 128

I must acknowledge and struggle against my partiality by making an effort to understand your reality and what it means for my own. I need to stop seeking certainty and acknowledge the complexity of our shared and colliding realities, as well as the tragic impossibility of all prevailing at once. It is this complexity that constitutes our reciprocal realities, and it is the conflict between our realities that constitutes us, whether we engage in it overtly or submerge it under a dominant view. ${ }^{129}$

Minow contends that by exploring our own stereotypes, welcoming anomalies, trying to understand how others understand, and constructing new bases for connection, ${ }^{130}$ individuals-even judges ${ }^{131}$ - can begin to confront people's differences. ${ }^{132}$ Minow's emphasis, in short, is less on political or social transformation than on the transformation of consciousness. She seeks to change how people think. ${ }^{133}$

${ }^{128}$ Gilligan, Different Voice at 173 (cited in note 122). For Gilligan's influence in legal scholarship, see, for example, Mary Joe Frug, Postmodern Legal Feminism at 166 n 40 (cited in note 12) (a sample of works that use and cite Gilligan's book).

${ }^{127}$ Martha Minow, The Supreme Court, 1986 Term, Forward: Justice Engendered, 101 Harv L Rev 10, 75 (1987).

128 Id at 82.

129 Id at 76.

130 Id at $79-81$.

131 Id at 81-95.

132 See generally Minow, Making All the Difference (cited in note 12).

${ }^{133}$ See, for example, Minow, 101 Harv L Rev at 15 (cited in note 127) ("Once we see that any point of view, including one's own, is a point of view, we will realize that every difference we see is seen in relation to something already assumed as the starting point. Then we can expose for debate what the starting points should be. The task for judges is to identify vantage points, to learn how to adopt contrasting vantage points, and to decide 


\section{B. The Situated Subject as Local Government Law}

The writers to whom I have just referred certainly do not form a single school of thought; indeed, they are likely to find it odd that I have grouped them together. But collectively, along with many others I have not mentioned, ${ }^{134}$ they could be a source of ideas for a local government law based on a notion of the situated self. I explore some of these ideas below through two doctrinal examples: the laws dealing with exclusionary zoning and condominium conversion. Before turning to these examples, however, it is important to begin to understand localities as situated subjects. The easiest way to do so is to focus on the relationship between America's cities and their suburbs; in this context, the mutually constitutive nature of municipalities seems virtually undeniable. ${ }^{135}$

"Every true suburb," in Robert Fishman's words, "is the outcome of two opposing forces, an attraction toward the opportunities of the great city and a simultaneous repulsion against urban life." 136 The suburbs would not be what they are without this love/ hate relationship with the city: if the recent, extraordinary American migration to the suburbs were fully successful and the central city ceased to exist altogether, the character of the suburbs would be radically different. There would, for example, be no place for those excluded by exclusionary zoning to live except the suburbs.

The identity of the modern city has been equally affected by the presence of its suburbs. Although cities existed before suburbs, the current social and economic problems of the modern city are, in part, the result of what has happened beyond the city (to use the literal definition of the word "suburb"137). This too can be illustrated by the impact on city life of exclusionary zoning: if no suburb excluded the poor or people of color, the nature of cities would be radically different. And there are countless other illustrations of the fact that the relationship between cities and suburbs is

which vantage points to embrace in given circumstances."); id at 72 ("These dilemmas ... become less paralyzing if you try to break out of unstated assumptions and take the perspective of the person you have called 'different.' ").

${ }^{134}$ See, for example, Cornell, Beyond Accommodation (cited in note 24); Benhabib, Situating the Self (cited in note 12); and Habermas, Communicative Action (cited in note 12)).

${ }_{135}$ The indispensable books on the history of suburbanization in the United States are Fishman, Bourgeois Utopias (cited in note 8); and Jackson, Crabgrass Frontier (cited in note 10). An insightful, if short, theoretical account that defines cities as inseparable from the network of other cities with which they are connected (and thereby contrasts them with states) can be found in Gilles Deleuze and Félix Guattari, A Thousand Plateaus: Capitalism and Schizophrenia 432-34 (Minnesota, 1987).

138 Fishman, Bourgeois Utopias at 26 (cited in note 8).

137 Id at 5. 
"not a relationship they choose (as in a voluntary association) ... but a constituent of their identity."138 Localities cause unemployment by attracting businesses from neighboring cities; they generate pollution that harms their neighbors as well as themselves; they zone for office complexes and shopping malls that change the lives of employees and customers in other towns; they educate people who move elsewhere in the area; they enact crime control policies that victimize people who live across the border. ${ }^{139}$ This section builds on the recognition of the inextricable entanglement between cities and suburbs.

Current local government law has rejected this understanding of local identity in its treatment of exclusionary zoning. The United States Supreme Court and most state courts have allowed localities to decide their zoning policies in the interests of their own residents with little regard to their effect on outsiders. ${ }^{140}$ Residents who desire to make their suburb into what Gregory Weiher has called a "theme park"- "a place of escape, a place where worries and cares must remain outside the gate"141 - are entitled to do so as long as they do not intentionally discriminate on the basis of race $^{142}$ and meet other minimal requirements. ${ }^{143}$ The impact on America of this aspect of local government law has been profound: as Weiher argues, the recognition of the legitimacy of jurisdictional boundaries has been a critical ingredient in the fragmentation of

138 Sandel, Liberalism and the Limits of Justice at 150 (cited in note 4). See text accompanying note 100 for a larger quote.

139 If a locality's crime control policies are too strict, criminals are given an incentive to engage in crime elsewhere; if its policies are too lax, criminals from elsewhere are kept in business-they have an extra place where they supplement their income. For other examples of inter-local effects, see text accompanying notes 307-20.

140 See, for example, Cadoux $v$ Planning \& Zoning Comm'n, 162 Conn 425, 294 A2d 582, 583-84 (1972); MacNeil v Town of Avon, 386 Mass 339, 435 NE2d 1043, 1044-46 (1982); Village of Arlington Heights $v$ Metropolitan Housing Development Corp., 429 US 252, 26871 (1977); Warth v Seldin, 422 US 490, 502-14 (1975); James v Valtierra, 402 US 137, 13843 (1971). For a review of decisions such as these, see Briffault, 90 Colum L Rev at 39-48, 101-09 (cited in note 3), and the works cited in Frug, Local Government Law at $485 \mathrm{n} 1$ (cited in note 31 ).

${ }^{141}$ Gregory R. Weiher, The Fractured Metropolis: Political Fragmentation and Metropolitan Segregation 188 (SUNY, 1991). A considerable literature exists on the relationship between cities and theme parks. See, for example, Michael Sorkin, ed, Variations on a Theme Park: The New American City and the End of Public Space (Hill \& Wang, 1992); Ada Louise Huxtable, The Unreal America, 39 NY Rev Books 24 (Dec 3, 1992).

142 Arlington Heights, 429 US at 264-68; Valtierra, 402 US at 141-42.

143 Most state courts give considerable deference to local zoning decisions, upholding them as long as they are reasonable; even activist state courts tend to focus not on exclusionary zoning as such but on whether a particular site should be rezoned. See Briffault, 90 Colum $\mathrm{L}$ Rev at $42-48$ (cited in note 3 ) (reviewing state cases). 
America's metropolitan areas. It has fostered not only the suburbs' ability to exclude potential residents but also their ability to recruit them: in a country where people frequently move, racial, ethnic, and class segregation can survive only if there are clear indications where "the right" kind of people live. ${ }^{144}$

Indeed, local government law's centered conception of suburban identity has done more than promote segregation: it has fostered a suburban consciousness that has become part of the identity of millions of Americans. This suburban consciousness combines the felt legitimacy of suburban separation with an acceptance of the benefits of race and class privilege. Not only does the city/suburb line often divide whites from blacks, but boundaries between suburbs also separate racial and ethnic groups, as well as the upper-middle-class from the middle-class and workingclass. ${ }^{145}$ Indeed, fears of racial and class integration, desires to protect "home and family, property, and community," and allegiance to suburban separateness define and reinforce each other. As a result, many people would feel personally threatened by a loss of the effectiveness of suburban boundary lines; the interdependence associated with a recognition of the situated nature of the self would be understood as opening them to vulnerability. ${ }^{146}$

Geographic boundaries have helped organize America's metropolitan areas in terms of gender roles as well. Suburban consciousness emphasizes boundaries not only between city and suburb but also between houses and between people. It fosters what M.P. Baumgartner calls a "moral minimalism": an avoidance of conflict, an emphasis on privacy and separation, and distanced social ties. ${ }^{147}$ To put the matter in Carol Gilligan's terms, if the centered subjectivity of the suburb were an attribute of a person, that person would be gendered male:

men and women may perceive danger in different social situations and construe danger in different ways-men seeing danger more often in close personal affiliation than in achievement and construing danger to arise from intimacy, women

144 Weiher, Fractured Metropolis at 167-70 (cited in note 141).

145 See, for example, Weiher, Fractured Metropolis at 8-10 (cited in note 141); Fishman, Bourgeois Utopias at 26, 82, 119 (cited in note 8).

${ }^{146}$ For a thoughtful study - and critique - of the modern fear of exposure and the role it has played in the development of cities, see Richard Sennett, The Conscience of the Eye: The Design and Social Life of Cities (Knopf, 1990).

147 M.P. Baumgartner, The Moral Order of a Suburb 10-13 (Oxford, 1988). See also Jackson, Crabgrass Frontier at 272-74 (cited in note 10); Sennett, Conscience of the Eye (cited in note 146). 
perceiving danger in impersonal achievement situations and construing danger to result from competitive success. The danger men describe in their stories of intimacy is a danger of entrapment or betrayal, because caught in a smothering relationship or humiliated by rejection and deceit. In contrast, the danger women portray in their tales of achievement is a danger of isolation, a fear that in standing out or being set apart by success, they will be left alone. ${ }^{148}$

Of course, since both men and women can have suburban consciousness, we need not read Gilligan as suggesting that there is a single male or female reaction to relationships. We can understand her notions of relationship as gendered cultural stereotypes: separateness, self-interest, and competitiveness are commonly imagined as masculine, while openness, caring and vulnerability are treated as feminine. ${ }^{149}$

An opposite gendered understanding of the city/suburb distinction is also possible. The suburbs can be understood not as male but as an extended women's sphere, a "sorority house with kids" as William Whyte called them in the $1950 \mathrm{~s}^{150}$ The classic suburb has been the domain of the domestic virtues associated with the role of the mother in the traditional nuclear family; the traditional father, but not the traditional mother, commutes to the city to work. ${ }^{151}$ Indeed, by making it more difficult for women to combine family life with working outside the home, the suburbs have contributed to the creation of the cult of domesticity. Of

148 Gilligan, Different Voice at 42 (cited in note 122).

149 See, for example, Mary Joe Frug, Postmodern Legal Feminism at 111-24 (cited in note 12). Baumgartner argues that, in the suburbs, the "ethic of care" is largely replaced by indifference. Baumgartner, Moral Order of a Suburb at 133 (cited in note 147). Other approaches also identify suburbs as male. Women disproportionately live in cities not suburbs, see Jo Freeman, Women and Urban Policy, in Catharine R. Stimpson, Elsa Dixler, Martha J. Nelson, and Kathryn B. Yatrakis, eds, Women and the American City 1, 2-10 (Chicago, 1981), and sociological studies suggest that women prosper more in cities than in suburbs. See, for example, Gerda R. Wekerle, Women in the Urban Environment, in id at 185, 195, citing William Michelson, Environmental Choice, Human Behavior and Residential Satisfaction (Oxford, 1977) ("[a]fter a move to suburbia women feel more alone and more isolated. In contrast, when families move to a downtown apartment a woman gains the most: her travel time declines and the family makes greater use of the public and cultural facilities of the city").

${ }^{150}$ William H. Whyte, Jr., The Organization Man 280 (Simon \& Schuster, 1956). See Susan Saegert, Masculine Cities and Feminine Suburbs: Polarized Ideas, Contradictory Realities, in Stimpson, et al, Women and the American City 93 (cited in note 149).

${ }^{151}$ See, for example, Saegert, Masculine Cities, in Stimpson, et al, Women and the American City (cited in note 149). Fishman, Bourgeois Utopias at 34, 190-91 (cited in note 8). 
course, this reading of the suburbs can be combined with the Gilliganesque reading rather than understood as its opposite: the cult of domesticity can itself be seen as male. ${ }^{152}$ But no matter which reading is adopted, it should be clear that confronting the issue of exclusionary zoning will challenge not only separation by race and class but also the ways in which our forms of urban life have built upon, and allocated, gender roles.

One court has already taken a step toward recognizing the interdependence between suburb and city in the exclusionary zoning context. In the well known case of Southern Burlington County NAACP $v$ Township of Mt. Laurel, ${ }^{168}$ the Supreme Court of New Jersey refused to allow localities to base their land use policy solely on the desires of local residents. Condemning the social consequences caused by the suburbs' effort to exclude the poor, the court held that every municipality in its zoning policy had to afford an opportunity for low and moderate income housing "at least to the extent of the municipality's fair share of the present and prospective regional need therefor." general welfare must be served ... in the field of land use regulation," the court stated:

Frequently the decisions in this state ... have spoken only in terms of the interest of the enacting municipality, so that it has been thought, at least in some quarters, that such was the only welfare requiring consideration. It is, of course, true that many cases have dealt only with regulations having little, if any, outside impact where the local decision is ordinarily entitled to prevail. However, it is fundamental and not to be forgotten that the zoning power is a police power of the state and the local authority is acting only as a delegate of that power and is restricted in the same manner as is the state. So, when regulation does have a substantial external impact, the welfare of the state's citizens beyond the borders of the particular

${ }^{132}$ For an argument about the relationship between the formation of suburbs and patriarchy, see Ann R. Markusen, City Spatial Structure, Women's Household Work, and National Urban Policy, in Stimpson, et al, Women and the American City 20 (cited in note 149). For an argument about the effect of the increase in the number of working women on urban policy, see Elizabeth A. Roistacher and Janet Spratlin Young, Working Women and City Structure: Implication of the Subtle Revolution, in id at 217. For a general account of the impact of the public/private distinction on women, see Jean Bethke Elshtain, Public Man/Private Woman: Women in Social and Political Thought (Princeton, 1981).

${ }_{188} 67$ NJ 151, 336 A2d 713 (1975) (Mt. Laurel I); 92 NJ 158, 456 A2d 390 (1983) (Mt. Laurel II).

1s4 Mt. Laurel I, 336 A2d at 724. 
municipality cannot be disregarded and must be recognized and served. ${ }^{185}$

The extent to which Mt. Laurel's notion of municipal legislation rejects the conception of the centered self is, of course, a matter of interpretation. One certainly can read the court's opinion as retaining the insider/outsider framework of the centered subject. The opinion allows cities to continue to serve the interest of the people who live within city boundaries unless there is a "substantial external impact" on outsiders. Thus the court might simply be requiring localities to pay attention to the injuries that self-interested activity causes others-in a way analogous to tort law or Mill's On Liberty ${ }^{158}$ - rather than changing the conception of the municipal self. In Sandel's terms, Mt. Laurel can be read as requiring localities to change merely the object and not the subject of their feelings and aspirations. ${ }^{167}$

But it is also possible to read the opinion as recognizing, in the context of exclusionary zoning, the regional construction of local identity. A locality's zoning policy, the court might be saying, affects not only its own identity but also the identity of other cities within the region. Suburban exclusiveness is dependent on the neighboring cities' refusal to exclude; some places have to be open for others to be closed. And just as the identity of the excluding suburb is enabled by its neighbors' openness, their identity as less "exclusive" is created by the exclusion. In Weiher's words, "[o]ne can only meaningfully speak of the type of people that live in a certain area because at the same time implicit reference is made to all of those people who do not live there." ${ }^{\text {"ss }}$ Under this reading, Mt. Laurel requires localities to accept a fair share of regional needs for low and moderate income housing not out of sympathy or altruism but out of the recognition that they are defined by, and define, others. ${ }^{109}$

It should not be surprising that cities in New Jersey might have found such a change of perspective hard to pull off. Since they had previously acted as centered subjects-and were still per-

155 Id at 726.

158 John Stuart Mill, On Liberty, in Mary Warnock, ed, Utilitarianism 126, 212-14 (Fontana, 1962).

157 Sandel, Liberalism and the Limits of Justice at 150 (cited in note 4).

158 Weiher, Fractured Metropolis at 167 (cited in note 141).

${ }^{160}$ Compare Minow, 101 Harv L Rev at 77-79 (cited in note 127) ("The plea for judges to engage with perspectives that challenge their own is not a call for sympathy or empathy. . .. [W] can learn to identify with others. . . . This goal demands a continual process of taking stock of the barriers we erect out of self-interest."). 
mitted to exercise that subjectivity in all contexts other than exclusionary zoning-it would be quite an accomplishment for cities to rethink their identity in response to a court order on a single topic. And, as we have seen, the case can be read as not even demanding such a rethinking. As a result, the subsequent history in New Jersey of the Mt. Laurel litigation-one that led to greater centralization of zoning decisions ${ }^{160}$-could readily have been anticipated. The localities' subjectivity remained unchanged and, as centered subjects, they had to be forced to behave altruistically.

The literature of the situated subject suggests that endowing localities with a decentered subjectivity requires much more than the court order in Mt. Laurel. To overcome exclusionary zoning, current local government law-other than cases like Mt. Lau$r^{2} l^{161}$ - has to be recognized, and rejected, both as a social policy and as a contribution to the construction of personal identity. Current law, having fragmented the metropolitan area, ${ }^{162}$ is perpetuated by the kind of person this fragmentation has nurtured. The problem with implementing Mt. Laurel or similar reforms is the power of this status quo. A central government's attempt to change it would strike the people who benefit from it as an astonishing invasion of their personal freedom. ${ }^{163}$ Yet it is unlikely that those who profit from current law will undo it themselves. How, then, can centered subjects ever come to embrace a vision of themselves as decentered, as interdependent?

One way to answer this question would build on the civic republican emphasis on the political construction of identity. It

\footnotetext{
${ }^{100}$ See Hills Development Co. $v$ Bernards Township in Somerset County, $103 \mathrm{NJ} 1$, 510 A2d 621, 632-34 (1986).

${ }_{102}$ A few other state courts have also recognized the importance of regional considerations in zoning matters. See, for example, Associated Home Builders of Greater Eastbay, Inc. $v$ City of Livermore, 18 Cal 3d 582, 135 Cal Rptr 41, 557 P2d 473, 483-90 (1976); Bristow $v$ City of Woodhaven, 35 Mich App 205, 192 NW2d 322, 324-30 (1971); Surrick v Zoning Hearing Bd., $476 \mathrm{~Pa}$ 182, 382 A2d 105, 107-12 (1977); Britton v Town of Chester, 134 NH 434, 595 A2d 492, 496 (1991); Berenson v Town of New Castle, 38 NY2d 102, 378 NYS2d 672, 341 NE2d 236, 242 (1975).

${ }^{182}$ For an extended analysis of the impact of local boundaries on metropolitan development, see Weiher, Fractured Metropolis (cited in note 141).

${ }^{163}$ Professor Briffault proposes state intervention as the solution to metropolitan fragmentation, see Briffault 90 Colum L Rev at 447-54 (cited in note 3), but he does not confront the power of the opposition to such an intervention. He simply recommends that the "ideology of localism . . . be jettisoned." Id at 454. But ideologies cannot just be "jettisoned." Neither state policy nor suburban consciousness is easy to change, as the difficulties in implementing Mt. Laurel demonstrate. Professor Briffault's failure to suggest how a centrally-imposed rejection of the ideology of localism might occur or why it might work is, in my view, a major defect in his recommendation that we rely on state power to transform our metropolitan areas.
} 
would take seriously my earlier quotation from Hannah Pitkin: "[o]nly in public life can we jointly, as a community, exercise the human capacity to 'think what we are doing,' and take charge of the history in which we are all constantly engaged by drift and inadvertence."164 Mt. Laurel's impact was limited by its strategy of treating every city as an individual decisionmaker required to confront regional needs by itself as a matter of thought. From a republican perspective, understanding the mutually constitutive impact of zoning decisions instead requires inter-city dialogue. "Feelings and ideas are renewed, the heart enlarged, and the understanding developed," Tocqueville observed, "only by the reciprocal action of men one upon another."165 If so, zoning policies should be worked out not centrally or by each municipality alone but through regional negotiations.

To establish such inter-city negotiations, institutional innovations are necessary; I discuss these in Section C below. But as republican writings emphasize, the success of inter-city negotiations will depend on the entitlements of the participants, the organization of the discussion, and the consequences not only of agreement but of failure to agree. ${ }^{186}$ The self may be formed through dialogue, but the dialogue will not change its participants if they can simply walk away because they do not like the deal. Not only is the experience of interdependence a prerequisite to doctrinal change but, paradoxically, doctrinal change is a prerequisite to creating the experience of interdependence. ${ }^{167}$ To eliminate exclusionary zoning and the consciousness that supports it, legal doctrine must recognize and break through this paradoxical structure. One ingredient in doing so, as Unger recommends, is expanding and developing existing alternative exclusionary zoning doctrines, such as the test expounded by $M t$. Laurel. ${ }^{168}$ Another ingredient, however, is to expose and build upon the decentered nature not just of the doctrine but of the suburban residents for whose benefit exclusionary zoning persists. Suburban residents not only disagree with each other

\footnotetext{
${ }^{164}$ Michelman, 97 Yale L J at 1504 (cited in note 108), quoting Pitkin, 9 Political Theory at 344 (cited in note 113). See note 113 and accompanying text.

168 Tocqueville, Democracy in America at 515 (cited in note 81).

${ }^{188}$ See, for example, Benhabib, Situating the Self at 95-113 (cited in note 12). For an analogous communitarian argument, see Joel F. Handler, Law and The Search for Community 143-61 (Pennsylvania, 1990). 92).

${ }^{187}$ For further exploration of this paradox, see Frug, 19 Urban Law 553 (cited in note

168 Unger, Critical Legal Studies Movement at 57-90 (cited in note 120) (elaborating such a methodology in terms of contract doctrine).
} 
on issues of race, class, gender, sexual orientation, the environment, population growth (and so forth), but they feel conflict themselves over these issues. Suburban self-protection might be undermined, therefore, by organizing regional negotiations not in terms of the suburb/city divide but in terms of the divisions that exist within both the suburbs and the city. In order to examine this strategy, I need to introduce a second local government law doctrine, the law of condominium conversion. ${ }^{169}$

Many cities have enacted legislation designed to limit the ability of landlords to convert rental housing into condominiums. This kind of legislation and exclusionary zoning raise comparable issues. Both restrict an owner's ability to control his property, and both do so in order to preserve an existing community by excluding outsiders. Exclusionary zoning enables suburbs to exclude the poor; condominium conversion legislation is an effort to protect low-income neighborhoods from gentrification. ${ }^{170}$ Indeed, condominium conversion legislation is one of the principal vehicles cities use for preserving neighborhood character. ${ }^{111}$ One could therefore imagine both being permitted (any community can control its own character) or both being forbidden (no community can exercise the right

\footnotetext{
180 Unger offers two additional strategies for decentralization. The first would give a locality a "conditional right to opt out of the norms established by higher authorities," with the condition ensuring that those affected, after the opting out occurs, "stand in a relation of relative equality." Roberto Mangabeira Unger, False Necessity: Anti-Necessitarian Social Theory in the Service of Radical Democracy 475 (Cambridge, 1987). Unger's second proposal would delegate power to localities as long as the power could "be prevented from serving to build up a local citadel of hierarchy" by (for example) "ad hoc supervisory boards, special rights of challenge and appeal, and the practice of transferring authority or resources to overlapping and competing bodies." Id at 476. Unger's proposals are very sketchy; they certainly are worth further exploration. But neither of them decenters the notion of membership in a decentralized community - the strategy I explore below.

${ }^{170}$ See Note, Displacement in Gentrifying Neighborhoods: Regulating Condominium Conversion Through Municipal Land Use Controls, 63 BU L Rev 955, 956 (1983). For academic assessments of the impact of gentrification, see Kathryn P. Nelson, Gentrification and Distressed Cities: An Assessment of Trends in Intrametropolitan Migration (Wisconsin, 1988); James Geoffrey Durham and Dean E. Sheldon III, Mitigating the Effects of Private Revitalization on Housing for the Poor, 70 Marq L Rev 1 (1986); J. John Palen and Bruce London, eds, Gentrification, Displacement and Neighborhood Revitalization (SUNY, 1984). For community residents' own accounts of gentrification, see Joseph Barry and John Derevlany, eds, Yuppies Invade My House at Dinnertime (Big River, 1987).

${ }^{171}$ Another is rent control. See Note, Reassessing Rent Control: Its Economic Impact in a Gentrifying Housing Market, 101 Harv L Rev 1835 (1988). See also Nordlinger v Hahn, 112 S Ct 2326, 2333 (1992) ("[T]he State has a legitimate interest in local neighborhood preservation, continuity, and stability. [Euclid v Ambler Realty Co., 272 US 365 (1926)]. The State therefore legitimately can decide to structure its tax system to discourage rapid turnover in ownership of homes and businesses, for example, in order to inhibit displacement of lower income families by the forces of gentrification or of established, 'mom-andpop' business by newer chain operations.").
} 
to exclude). As it turns out, however, suburban exclusion is easier to accomplish than urban exclusion because current local government law's treatment of condominium conversion legislation is radically different from its treatment of exclusionary zoning.

Courts have taken the need to protect the rights of property owners from excessive governmental regulation much more seriously when dealing with condominium conversion legislation than when dealing with exclusionary zoning. ${ }^{172}$ In Massachusetts, for example, the Supreme Judicial Court has invoked several local government law doctrines to limit cities' power to prevent the conversion of rental housing. Although the Massachusetts state constitution allows cities to exercise home rule, the Supreme Judicial Court has held that the home rule power does not include the ability to pass condominium conversion legislation. Regulating the landlord/tenant relationship, the court has reasoned, falls within the exception to cities' home rule power that prevents them from enacting "private or civil law."173 Unable to use their home rule power, Massachusetts cities must therefore seek specific state authorization to pass condominium conversion legislation. Under Dillon's Rule, however, specific grants of authority to cities are nar-

172 Deference to local discretion in zoning has been commonplace in American law since 1926. Ambler Realty, 272 US 365. The statement in the text-describing this deference as a concession to government regulation of private enterprise-is the conventional reading. See, for example, Penn Central Transportation Co. $v$ New York City, 438 US 104, 125 (1978). But the opposite story can also be told:

[Z]oning[ ] originated as early as 1880 in Modesto, California, where it had been used to remove Chinese laundries: a particularly apt beginning, since thereafter one of its principal functions was to safeguard property values by excluding undesirable land uses and undesirable neighbours. And ... the city that took the lead in the zoning movement from 1913 on, New York City, was impelled to do so by the complaints of Manhattan retailers who, complaining that industrial incursions were threatening their profits, appealed loudly to "every man who owns a home or rents an apartment"; the city's Commission on Building Heights accepted their argument that zoning secured "greater safety and security in investment." And the historic 1926 Supreme Court decision, Euclid v. Ambler, which confirmed the general validity of zoning, seems to have accepted Alfred Bettman's argument that its point was to enhance property values. The point at issue, significantly, was whether land should be zoned industrial or residential.

Peter Hall, Cities of Tomorrow: An Intellectual History of Urban Planning and Design in the Twentieth Century 292-93 (Basil Blackwell, 1988) (citations omitted). Under this alternative reading, permitting zoning and preventing condominium conversion are two aspects of the same policy-one that favors the rights of property owners. See note 45 and accompanying text; Frug, 93 Harv L Rev at 1101-09 (cited in note 11). Compare Nordlinger, $112 \mathrm{~S}$ Ct at 2333.

${ }^{173}$ Marshal House, Inc. $v$ Rent Review and Grievance Board of Brookline, 357 Mass 709, 260 NE2d 200, 205-07 (1970). See also Bannerman v City of Fall River, 391 Mass 328, 461 NE2d 793, 794-96 (1984). 
rowly construed; accordingly, the court has held many specific state authorizations insufficient to permit condominium conversion legislation. ${ }^{174}$ These condominium conversion cases, in short, exemplify the aspect of local government law that curbs city power thought to invade the rights of minorities, ${ }^{176}$ just as most exclusionary zoning cases exemplify the aspect of local government law that enhances suburban power. Moreover, the exclusionary zoning cases do not help cities: city residents cannot challenge city zoning laws that facilitate gentrification on the grounds that they exclude the poor. ${ }^{178}$ As a result, those with enough money can profit from both doctrines: they can isolate themselves in the suburbs or buy up inner city neighborhoods through gentrification.

Examining exclusionary zoning and condominium conversion law together does more than simply provide yet another example of the social policy local government law now embraces. It can help us break out of the clichéd vision of open cities and closed suburbs often imagined in the context of exclusionary zoning. The effort to pass condominium conversion legislation demonstrates that the instinct for exclusion is not limited to the suburbs. Feelings of race and class privilege, desires to protect "home and family, property, and community," and allegiance to separateness exist on both sides of the city/suburb boundary. Many blacks fear the weakening of the city/suburb line as an attack on the political power they have gained in central cities, ${ }^{177}$ and many residents of ethnic neighborhoods fear integration as a destruction of their community. The prevention of gentrification, like exclusionary zoning, enables peo-

${ }^{174}$ Steinbergh $v$ Rent Control Board of Cambridge, 406 Mass 147, 546 NE2d 169, 171 74 (1989); Greater Boston Real Estate Bd. v Boston, 397 Mass 870, 494 NE2d 1301, 1304-06 (1986). But see Grace v Town of Brookline, 379 Mass 43, 399 NE2d 1038, 1042-45 (1979) (upholding amendments to a town's by-laws that restricted the ability of condominium owners to evict tenants); Flynn v Cambridge, 383 Mass 152, 418 NE2d 335, 337-39 (1981) (upholding an ordinance regulating eviction from and condominium conversion of housing subject to rent control).

17s The Massachusetts cases are not unusual. Other state courts have also invalidated local efforts to restrict condominium conversions. See, for example, City of West Hollywood $v$ Beverly Towers, 52 Cal 3d 1184, 805 P2d 329, 331-35 (1991); City of Miami Beach v Rocio Corp., 404 S2d 1066, 1069-71 (Fla App 1981); Rockville Grosvenor, Inc. v Montgomery County, 289 Md 74, 422 A2d 353, 360-67 (1980); Hampshire House Sponsor Corp. v Fort Lee, 172 NJ Super 426, 412 A2d 816, 819-21 (1979).

${ }^{178}$ Asian Americans for Equality $v$ Koch, 72 NY2d 121, 531 NYS2d 782, 527 NE2d 265, 268-73 (1988). See also Case Comment, Asian Americans for Equality v. Koch, 102 Harv L Rev 1092 (1989).

${ }^{177}$ See Comment, Black Neighborhoods Becoming Black Cities: Group Empowerment, Local Control and the Implications of Being Darker Than Brown, 23 Harv CR-CL L Rev 415 (1988) (urging black communities to pursue incorporation and separation rather than integration in order to promote their needs). 
ple to preserve comparatively homogeneous communities and advances the interests that the members of the community have in common. City and suburban residents thus have similar reasons to protect territorial identity: racial pride, feelings of community, fear of outsiders, and preference for their own way of life over that lived on the other side of the border. ${ }^{178}$

Examining exclusionary zoning and condominium conversion law together also helps demonstrate that some people on both sides of the border want to move to the other side. Some city residents may see the suburbs as a means of escape, but some suburban residents want to escape to the city as well. Gentrification, like the move to the suburbs, reflects the desire for a better life. Moreover, exclusionary zoning limits the ability to escape in both directions. It prevents the poor from moving to the suburbs, and it contributes to the decay of the inner cities that restricts the possibilities for gentrification. Like the urban poor, suburban residents who would prefer to live across the border often can not find an acceptable place to live. A different local government law could enable greater mobility in both directions, a mobility that even some who would not move would like to encourage. Gentrification brings an increase in the tax base and spending in the city; ${ }^{178}$ integration brings values of diversity that some suburbanites favor. Of course, these feelings of openness to newcomers exist alongside the desire to exclude them that I have already mentioned, just as the urge to locate elsewhere co-exists with the feeling of comfort associated with staying put.

This conflict between the desires to exclude others and to integrate with others replicates the structure of identity formation described in the communitarian literature. ${ }^{180}$ Local government law could help undermine the power of suburban consciousness by or-

178 For an analysis of neighborhood efforts on both sides of the city/suburb border to oppose human service facilities and low income housing (as well as hazardous waste facilities and landfill sites), see Michael Dear, Understanding and Overcoming the NIMBY Syndrome, 58 J Am Planning Ass'n 288 (Summer 1992).

${ }^{170}$ The "case for gentrification" is concisely argued in William H. Whyte, City: Rediscovering the Center 325-30 (Doubleday, 1988).

The implicit assumption of the gentrification concept is that the chief threat to housing for the poor is the improvement of neighborhoods. The problem is the opposite. The chief threat is the deterioration of neighborhoods. The poor are not being hurt by middle-class investment. They are being hurt by disinvestment-by landlords and owners who let buildings go to rot, who walk away from them, who torch them.

Id at 328. See also Note, 63 BU L Rev at 955 (cited in note 170).

180 See text accompanying note 119; Unger, Knowledge and Politics 284-89 (cited in note 115) ("The Dilemmas of Communitarian Politics"). 
ganizing inter-local negotiations to highlight these contradictory instincts. Many different people could bring these conflicts into regional negotiations, because there are a multitude of ways that the fight over closure and openness occurs within both suburbs and cities. There are advocates of race consciousness and proponents of racial integration; residents who prefer stability and residents who prefer growth; property owners who want to preserve the existing community and property owners who want to profit from development or gentrification; people who fear the dangers of city life and people who love living in cities; parents who feel that the suburbs are "a great place to raise a family" and kids who consider the suburbs vacuous; women who feel trapped by living in the suburbs and women who feel protected by living there; activists seeking to rid their neighborhood of "undesirables" and the undesirables themselves. ${ }^{181}$ The conflicting instincts of inclusion and exclusion can also be brought into the negotiations by ensuring the participation of different suburbs and city neighborhoods. Although suburbs sometimes collectively define themselves in contrast to the city, the competition between them, their division along class lines, and their desire to distinguish themselves from each other prevent them from having a single unified interest. Differences among city neighborhoods-and between "the neighborhoods" and downtown-deny the city a single identity as well.

As I will argue in Section C, institutional innovations are indispensable to structuring inter-city negotiations in terms of these conflicts. But the entitlement system of municipalities under the laws of exclusionary zoning and condominium conversion must also be changed. The instincts for inclusion and exclusion both have to be embraced by local government law. The extent of inclusion and exclusion have to become the result of inter-city bargaining, not the product of entitlements brought to the bargaining table. Those who want to move to a neighborhood should not face communityimposed obstacles to doing so (the community should have no right to exclude them). But the ability to maintain a relatively homogeneous community should also not be forbidden (there should be no right to be included). ${ }^{\mathbf{1 8 2}}$ If suburbs and city neighborhoods

\footnotetext{
$18 x$ See, for example, Gary Peller, Race Consciousness, 1990 Duke L J 758 (contrasting integrationist and race-conscious perspectives); works cited in notes 147-52 and accompanying text; Whyte, City at 156-64 (cited in note 179) (on "The Undesirables"); Austin, 65 S Cal L Rev 1769 (cited in note 23) (analyzing attitudes toward black lawbreakers); Hall, Cities of Tomorrow at 297-304 (cited in note 172) ("Suburbia: The Great Debate").

162 There are a variety of ways to bring this legal regime about. One could create a privilege to move to a community by not allowing the community to stop (by zoning or
} 
are denied a legal right to exclude, they will be sufficiently vulnerable that they are likely to be anxious to make a deal rather than to walk away. And if the formation of relatively homogeneous communities remains a possibility, people seeking inclusion will want to make a deal as well: they will want to find a way actually to move to the community, a prospect that, as the history of Mt. Laurel suggests, is by no means easy to achieve. ${ }^{183}$ Not only would the extent of acceptable exclusion become negotiable but the negotiations could also face up to the kinds of questions local government law now does not even have on the agenda. Would the reallocation of resources from suburb to city or neighborhood to neighborhood be preferable to changing neighborhood character? ${ }^{184}$ Where will the excluded people go?

As Unger's work suggests, transformation of America's metropolitan areas and of the forms of personal identity that they nurture will require more than adopting this republican strategy of changing the structure and rules of political dialogue about exclusion. ${ }^{185}$ Local government law intersects with the rest of the legal system in a multitude of ways; transformative change requires modifying the entitlements not only of localities but of the people who live within them. Restrictions on condominium conversion legislation, for example, give property owners considerable leeway to gentrify, while lack of protection for suburban property owners who want to develop low and moderate income housing give the suburbs substantial power to exclude. ${ }^{186}$ Altering these legal rules could thus affect the outcome of negotiations over both urban and suburban exclusion. Similarly, those displaced by condominium conversion and exclusionary zoning currently have little legal protection and therefore would not be taken seriously in a negotiation process. The post-war gentrification efforts known as urban re-

otherwise) a sale of property within the community to an outsider. One could simultaneously create a privilege (but not a right) of exclusion by giving an outsider no right to move to a community if no one within the community were willing to sell to him. For the definition of the terms privilege, right, and no-right, see Wesley Newcomb Hohfeld, Some Fundamental Legal Conceptions as Applied in Judicial Reasoning, 23 Yale L J 16, 32-44 (1913).

${ }^{28 s}$ See, for example, Robert Hanley, Affordable Housing in Jersey Is Still an Elusive Goal, NY Times B1 (Oct 24, 1988).

${ }^{186}$ The New Jersey Fair Housing Act, which transfers authority over compliance with Mt. Laurel from the courts to a Council on Affordable Housing, allows municipalities to enter into a contract by which a city can, in exchange for money, transfer up to $50 \%$ of its fair housing obligations to another city. NJ Stat Ann § 52:27D-312 (West 1991).

${ }^{185}$ Unger, Critical Legal Studies Movement (cited in note 120); Unger, Politics (cited in note 120 ).

${ }^{186}$ See text accompanying notes 153-76. 
newal gestured toward a recognition of the costs imposed on those displaced, ${ }^{187}$ but reinforcement of that recognition could transform the negotiation process. So might changing the entitlements of other possible participants in the negotiations: city neighborhoods opposed to "downtown" interests, women who want to ameliorate the work/family conflict by living near their work, people who prefer race consciousness to racial integration, people others label "undesirables."188

It is not possible to list here the rule changes that would further the negotiation process; answers are likely to vary from locality to locality. Only experience will teach us how any particular modification works in any specific context. But an extensive transformation of the legal system will no doubt be necessary. It would be a mistake to reject such a transformation as improper social engineering. Current law is itself social engineering. Not just local government law but federal support of highways linking suburb and city, federal guarantees of housing loans, federal income tax deductions for mortgage interest, and federal support for urban renewal-among many other government policies-have helped create our current modern metropolitan areas. ${ }^{188}$ The issue facing us is not whether the legal system will promote one form of metropolitan area over alternatives; that is unavoidable. The issue is deciding which one to promote.

187 Uniform Relocation Assistance and Real Property Acquisition Policies Act of 1970, 42 USC \& 4601 (1992); Demonstration Cities and Metropolitan Development Act of 1966, 42 USC $\S \S 3301,3307$ (1992); Housing Act of 1949, 81st Cong, 1st Sess, ch 338 (1949). For an assessment of these statutes, see U.S. Department of Housing and Urban Development, Displacement Report (Feb 1979). For a history of urban renewal efforts, see Teaford, Urban Revitalization at 107-62, 214-17 (cited in note 10).

${ }^{183}$ See note 181 and accompanying text.

189 Peter Hall argues that there were four principal foundations for the suburban boom: new roads, zoning, government-guaranteed mortgages, and the baby boom. The 1956 Federal-Aid Highway Act ("[t]he greatest public-works programme in the history of the world") was, he contends, the principal spur to the new roads; and federally insured mortgages, pursuant to the National Housing Act, fostered suburban development by revolutionizing the way the nation's residential housing market was financed. Moreover, federal policies for evaluating mortgage applications not only favored the suburbs but discriminated against racial minorities. See Hall, Cities of Tomorrow at 291-94 (cited in note 172). For a history of the federal government's anti-urban biss and of the ways in which its mortgage-guarantee program helped segregate metropolitan areas along the lines of race, see Jackson, Crabgrass Frontier at 190-218 (cited in note 10). Kenneth Jackson adds to Hall's list the importance of federal mortgage deductions. Id at 293-94. The federal urban renewal policies of the 1950 s and 1960s also accelerated suburban prosperity and urban decline. See Teaford, Urban Revitalization at 214-17 (cited in note 10). In sum, there would be no suburbs, in the form in which we know them, without these federal initiatives and the zoning policies discussed in the text. 
Reform of exclusionary zoning and condominium conversion law is only one step in such an effort. The Mt. Laurel court was mistaken when it treated some local regulations as having "little, if any, outside impact."180 This statement perpetuates the pretense that local government law's embrace of centered subjectivity reflects a real inside/outside distinction, with exclusionary zoning simply an exception to this general rule. Fully confronting the impact of the current fragmentation of our metropolitan areas requires abandoning this pretense: it requires recognizing that every local decision-from schools to sanitation, from housing policy to transportation policy, from gun control to pollution control-affects outsiders. Localities need to recognize across the board that their identity is "defined to some extent by the community of which they are a part."191

\section{The Institutional Implications of Situated Subjectivity}

To build local government law on the notion of situated subjectivity, we need to organize local institutions, as well as legal doctrine, in terms of inter-local relationships. By allocating power principally to individual cities or the state, current local government law treats as irrelevant the fact that localities are situated within a region. Legal decisionmaking therefore oscillates between increasing the centralized power of the state government and empowering localities in a way that affects their neighbors without the neighbors' participation in the decisionmaking process. It is time to create another option.

Of course, many states have already created public authorities to deal with specific issues on a regional basis (such as transportation, natural resources, and parks) and, in a few parts of the country, regional governments have assumed a considerable share of local political power. ${ }^{182}$ But neither of these regional forms fosters

$190336 \mathrm{~A} 2 \mathrm{~d}$ at 726 . See text accompanying note 155 for a larger quote.

101 Sandel, Liberalism and the Limits of Justice at 150 (cited in note 4). See text accompanying note 100 for a larger quote.

${ }_{102}$ On regional public authorities, see, for example, Briffault, 90 Colum L Rev at 375-78 (cited in note 3); Robert A. Caro, The Power Broker 614-36 (Vintage, 1975); Comment, An Analysis of Authorities: Traditional and Multicounty, 71 Mich L Rev 1376 (1973). On regional governments, see, for example, Note, It's Time to Create a Bay Area Regional Government, 42 Hastings L J 1103 (1991); C. James Owen and York Willburn, Governing Metropolitan Indianapolis: The Politics of Unigov (California, 1985); James F. Horan and G. Thomas Taylor, Jr., Experiments in Metropolitan Government (Praeger, 1977); Note, The Urban County: A Study of New Approaches to Local Government in Metropolitan Areas, 73 Harv L Rev 526 (1960). For a history of attempts to assert regional control over cities and suburbs, see Teaford, City and Suburb (cited in note 10). 
inter-local relationships; each simply replaces the city's version of the centered subject with its own. Public authorities centralize power in a corporate-style bureaucracy. They are structured more like businesses than like government: their managers are appointed not elected, they are exempted from many limits placed on governmental entities, their authority is defended in terms of expertise, and they replace rather than involve local democratic decisionmakers. ${ }^{193}$ Regional governments, by contrast, centralize power in yet another form of sovereignty. They are sub-state governments with qualities intermediate between those of the state and cities: like the state, they can exercise power across the region; like cities, they are subservient to state power. ${ }^{194}$ Although both of these entities decrease the authority of city governments, neither transforms the subjectivity of the region's localities in any way.

New forms of regional organization have to be created to foster a situated conception of local identity. One possibility would be to decentralize authority from the federal and state governments to localities under a system of rules established by a regional legislature authorized to allocate entitlements to the area's cities and suburbs. The purpose of such a regional legislature would not be to act as a regional government or ape the powers of the state. Instead, it would be a democratic version of the idea of regional planning embodied in federal legislation of the 1960s and 1970s. ${ }^{195}$ These federal statutes sought to inject a regional voice into local decisionmaking by requiring local decisions to be consistent with a regional plan; Congress hoped that such a requirement would overcome the selfish pursuit of local self-interest by forcing each locality to consider the impact of their actions on the region as a whole.

193 See, for example, Municipal Building Authority v Lowder, 711 P2d 273, 277-80 (Utah 1985); Ball v James, 451 US 355, 362-72 (1981); Salyer Land Co. v Tulare Lake Basin Water Storage District, 410 US 719, 728-29 (1973); Comment, 71 Mich L Rev at 1429 (cited in note 192).

104 See, for example, City of Miami v Metropolitan Dade County, 407 S2d 243, 244-45 (Fla App 1981); Metropolitan Dade County v City of Miami, 396 S2d 144, 146-48 (Fla 1980).

${ }^{108}$ For example, National Health Planning and Resources Development Act of 1974, Pub L No 93-641, 88 Stat 2225, 2232-35, codified at 42 USC \$§ 201 et seq (1982), repealed by Pub L No 99-660, 100 Stat 3799 (1986); Housing and Urban Development Act of 1968, Pub L No 90-448, 82 Stat 476, 526-32, codified at 42 USC $\$ \S 1401$ et seq (1970), repealed by the Omnibus Budget Reconciliation Act of 1981 \$ 313, Pub L No 97-35, 95 Stat 398 (1981); Comprehensive Health Planning and Public Health Services Amendments of 1966, Pub L 89-749, 80 Stat 1180, 1180-90, codified at 42 USC § 246 (1992); Public Works and Economic Development Act of 1965, Pub L No 89-136, 79 Stat 552, 564-69, repealed by the Omnibus Budget Reconciliation Act of $1981 \S 1821$ (a), Pub L No 97-35, 95 Stat 766 (1981). See David C. Ranney, Planning and Politics in the Metropolis 80-83 (Merrill, 1969). 
But the effect of these federal statutes was limited. They made regional considerations relevant only in the context of allocating federal grants; they created as many different regional planning agencies as there were subject matters to plan for; they concentrated on requiring agencies to prepare a written plan rather than on an ongoing process of regional negotiations; and they relied on existing political boundaries in the organization of the regional planning process. Nevertheless, the germ of the idea was sound. The object was not to have regional bodies replace local decisionmaking but to require localities, when making their decisions, to take the interests of other localities within the region into account.

As just mentioned, the task of the regional legislature would be to perform one specific function of the state legislature (and the state courts): the allocation of entitlements to local governments. An example of such an allocation is the articulation of standards-such as the Mt. Laurel standard-that describe the extent to which localities must accommodate the interest of others in the region when they decide their land-use policies. ${ }^{196}$ But there are also countless other entitlement issues facing local governments-What portion of the funds derived from the property tax can a locality use solely for its own schools? Can a locality exclude a facility the region needs (a waste dump)? What incentives can a locality offer a business in a neighboring jurisdiction to move across the border? Are stricter gun control laws more appropriate in one area of the region than elsewhere? Current local government law has clearly established that the kinds of entitlement questions I have just proposed cannot be distinguished "in principle" from substantive local decisionmaking. ${ }^{197}$ One could frame every issue as an entitlement question and thereby eliminate city decisionmaking altogether (and frame every issue as suitable for local resolution and thereby eliminate regional decisionmaking altogether). What, then, is the distinction that I am making between the entitlement allocation function of a regional legislature and a regional government?

The answer to this question must be found not in an analytical distinction between entitlement allocation and governance but

196 See text accompanying notes 153-55.

197 See, for example, Garcia v San Antonio Metropolitan Transit Authority, 469 US 528 (1985) (rejecting the "traditional governmental functions" standard for state regulatory immunity); City of La Grande v Public Employes Retirement Board, 281 Or 137, 576 P2d 1204, 1212-15 (1978) (rejecting judicial interest balancing as a way to protect local autonomy). 
in the way the regional legislature is organized. The regional legislature itself (and not the courts or the cities) should have the power to determine which questions it (rather than the localities) can decide, ${ }^{188}$ but the legislature should be structured to encourage its members not to exercise power themselves but to turn the legislature into a forum for inter-local negotiations about how to decentralize power. ${ }^{199}$ The best chance of doing so, in my view, lies in electing representatives from neighborhoods rather than from the city or the suburbs. By organizing the legislature on the basis of the subdivisions of the city and the suburbs to which people feel most attached, its members would be sufficiently connected to their communities that they would be under constant pressure to decentralize power. But they could not achieve such a goal without convincing fellow legislators that decentralization was a good idea. The members of the legislature would thus regularly experience the conflict between attachment to their neighborhood and the pull of the larger community, a conflict that parallels the struggle between the attachment to the self and to others embodied in the notion of the situated self. The contradictory pulls of the situated self-between particularism and universalism, between immanence and transcendence ${ }^{200}$-would thereby become the structure of decisionmaking about decentralizing power. To be sure, additional institutional innovations might well be necessary to prevent legislators from becoming so enamored of their own power that they attempt to transform the regional legislature into a regional government. Requiring legislators to appear regularly before neighborhood meetings to report on legislative activity, allowing those at the meeting to vote on the kinds of compromises that the legislators are authorized to make, enabling neighborhood residents to control legislative salaries and perks, establishing term limits for those serving in the legislature-ideas such as these, from sources

${ }^{108}$ This is the position of both Garcia, 469 US 528, and La Grande, 576 P2d 1204.

190 Justice Blackmun asserted in Garcia, 469 US at 547-55, that Congress was organized to represent the interest of states and that it operated as a forum for inter-state dialogue. This is the classic image of how legislatures work: legislators are elected locally to ensure that the legislature is a collectivity of local voices. There is, however, considerable doubt that Congress-particularly since the adoption of the Seventeenth Amendment (electing senators by popular vote rather than by the state legislatures)-actually represents the interest of states as such. And there is absolutely no evidence-given the lack of correspondence between Congressional districts and city lines-that Congress represents city interests or that it operates as a form of inter-city dialogue (and federal/city relationships were the precise issue in Garcia). Decentralization of power, in my view, requires transforming Justice Blackmun's assertions about how representative democracy works into fact.

${ }^{200}$ See Unger, Knowledge and Politics at 284-89 (cited in note 115). 
as varied as the history of New England towns and Marx's analysis of the Paris Commune, suggest that regional legislatures can be organized to frustrate the dynamic of centralization. ${ }^{201}$ Localities will not be able to get everything they want from such a structure, but they are likely to be able to gain more power than they now have or than they would have if they ceded authority to a regional (or state) government.

A blizzard of issues is raised by this proposal that need further work. Current interpretations of the Equal Protection Clause limit the ability to adopt neighborhood lines precisely. ${ }^{202}$ Neighborhood representation might be inadequate to foster enough conflict between the desire for decentralization and the need for coordination; it might be necessary to have a wider variety of people from both sides of the city/suburb border in the legislature. ${ }^{203}$ Perhaps each neighborhood should be represented by more than one individual (by adopting a form of proportional representation) so that different factions within the neighborhood can say what the neighborhood stands for. My purpose at the moment is not to resolve all these issues but simply to persuade you that a regional legislature organized by neighborhood could foster the situated identity of local governments: it could enable the rules under which localities operate to be decided collectively by the localities themselves.

Once cities and suburbs learn, through battles in the regional legislature, what the regional impact of their decisions are, they can begin to internalize this perspective. They can improve their

\footnotetext{
${ }^{202}$ In the eighteenth century, New England towns successfully wrested power from a domineering state government by requiring representatives to be local residents, establishing a town mandate instructing the representative on how to vote on specific issues, instituting annual elections, controlling the representatives' salary, and using the legislative journal as an instrument of surveillance of legislators' activities. Michael Zuckerman, Peaceable Kingdoms 19-28 (Norton, 1970). Marx suggested a remarkably similar structure for the Paris Commune. Karl Marx, The Civil War in France, in Robert Tucker, ed, The MarxEngels Reader 526, 554-57 (Norton, 1972).

${ }^{202}$ Avery v Midland County, 390 US 474 (1968), imposed on local governments the "one person, one vote" requirement first articulated for states in Reynolds $v$ Sims, 377 US 533 (1964). And Board of Estimate v Morris, 489 US 688 (1989), has made it clear that this requirement does not permit a substantial variation from strict equality because of neighborhood feeling or history. To be sure, regional planning agencies have been organized without respecting the "one person, one vote" principle, and this structure has been declared constitutional on the grounds that planning agencies are not elective bodies and do not exercise governmental functions. Education/Instruccion, Inc. $v$ Moore, 503 F2d 1187, 1189 (2d Cir 1974). These defenses, however, would not be available to regional legislatures as I envision them. Thus, unless Justice Harlan's dissent in Avery were to become law-a dissent explicitly based on the need for flexibility in creating regional governmental institutions, 390 US at 493-94 - drawing of neighborhood boundaries will require considerable care.

${ }^{203}$ See text accompanying notes 180-81.
} 
own "capacity for reflexively critical reconsideration . . . by reaching for the perspectives of other and different persons." erable authority could then be delegated to cities, suburbs and neighborhoods; the review (and potential review) by the regional legislature would help overcome the fear of the centered subject that has limited the possibility of decentralizing power in America. There surely would no longer be much reason to prefer state over local decisionmaking. Regions are as diverse as states, and they therefore can serve the purpose of protection against parochialism usually advanced for state power. ${ }^{205}$ Moreover, little democratic participation in their decisionmaking is possible because of the size of most states (and of most state legislative districts). Indeed, many regions in America cross state boundaries, and state decisionmaking is likely to increase the fragmentation of metropolitan regions rather than solve it. Decentralizing power to cities, suburbs, and neighborhoods thus seems a far better alternative than state decisionmaking, as long as regional views are incorporated into their decisionmaking.

Other mechanisms exist that might also foster a situated identity for localities. Although a regional legislature can lay down rules about local entitlements, case-by-case applications of these rules are necessary as well. One could therefore create a citizen group of (say) 100 people to serve for a stated period of time as public representatives to evaluate the localities' performance of this task; the group could be chosen from the metropolitan area by lot, rather than by election or through interest group representation, to ensure that its members were a microcosm of the region. ${ }^{208}$ Once constituted, the group could be authorized, for example, to judge disputed instances of exclusion (how many centers of the homeless are appropriate in this neighborhood?) or extra-territorial effects (what restrictions on pollution are necessary before rezoning for industrial development?). One way to understand this proposal is to see it as an expanded and modified form of the jury: as with jury service, citizens would be expected to devote a portion of their time to public policy decisionmaking. ${ }^{207}$ Like jurors, these public representatives would listen to and evaluate expert testi-

\footnotetext{
204 Michelman, 97 Yale L J at 1528 (cited in note 108). See text accompanying note 109 for a larger quote.

20s See, for example, Briffault, 90 Colum L Rev at 446-54 (cited in note 3).

206 Similar mechanisms are explored in Frug, $40 \mathrm{U}$ Toronto $\mathrm{L} J$ at 570-73 (cited in note 11).

207 Of course, such a system would have to establish a method of dealing with excuses and exemptions from service, problems that have plagued the jury system. As experience
} 
mony and would apply legal rules to the facts as they found them. And the regional legislature would retain the authority to ensure that they kept within this mandate. But, as Tocqueville emphasized, it is important to see juries as political institutions, not just as vehicles for deciding issues.

Juries invest each citizen with a sort of magisterial office; they make all men feel that they have duties toward society and that they take a share in its government. By making men pay attention to things other than their own affairs, they combat that individual selfishness which is like rust in society. ${ }^{208}$

If so, the institution of the jury is too important to be limited to deciding questions raised by civil or criminal trials. The need to experience the opposite pulls of community and self can become a vehicle for involving ordinary citizens in the experience of local democratic decisionmaking. The more rapid the turnover of this citizen group and the greater the number of issues decided by this process, the more widespread this learning experience would become.

A council of mayors from the region's cities and towns might also be a helpful forum for discussing regional needs and priorities. Given the radical differences in the population of the different jurisdictions, it would be a mistake to give such a council decisionmaking power. Nevertheless, even as an advisory body, a council of mayors can inform individual localities about inter-local needs and thereby speed the process of internalizing these needs into city decisionmaking. This experience of forming a city agenda in discussion with neighboring city leaders might also redirect a city's energy. If, for example, the mayors could agree on a plan of decentralization, they could be an effective lobbying force in the regional legislature. But in order to agree they would have to confront their differences. Like the other institutional forms suggested here (and many others that might be proposed), the council of mayors is based on a strategy about how to build unity out of differences: a sense of situated identity is more likely to be formed by small groups living near each other than by the actions of a central government.

with the jury has demonstrated, the greater the loopholes, the less representative the public process.

${ }^{208}$ Tocqueville, Democracy in America at 274 (cited in note 81). 
D. Beyond the Situated Subject

I think that local government law-and the chances for effective decentralization of power-would be vastly improved if localities were treated as situated subjects. Accomplishing such a change would take an extraordinary amount of political effort and doctrinal innovation-as much as, perhaps more than, it is sensible to expect. Yet the situated self is but one of the possibilities for basing local government law on a decentered subject, and it is one that, at least for me, has significant problems. Two interrelated difficulties seem worth mentioning here: romanticism and hedging.

Much of the literature of the situated self suffers from an overly romantic view of human connection. Somehow, it suggests, we will all recognize our connection with each other. Last paragraphs of articles and books written in this tradition are a place to look for this sentiment. Here's Minow: "By taking difference into account, we can overcome our pretended indifference to difference, and people our worlds with those who can surprise and enrich one another."209 And Sandel: "when politics goes well, we can know a good in common that we cannot know alone."210 And Unger: "If someone were to ask us why we want to live in the present in this way, we should answer: first, because this is the kind of being we really are and, second, because by living in this fashion we empower ourselves individually and collectively."211 These quotations are examples of romanticism not just in the popular sense of sentimentality but in the sense associated with pre-modernist nineteenth-century thought:

Largely from the nineteenth century, we have inherited a romanticist view of the self, one that attributes to each person characteristics of personal depth: passion, soul, creativity, and moral fiber. This vocabulary is essential to the formation of deeply committed relations, dedicated friendships, and life purposes. $^{212}$

And, one might add, the same vocabulary is essential to optimism about inter-city negotiations as well.

The hedging problem can be seen in the literature's use of phrases like "partly" when defining the relationship between self and others. For example, Charles Taylor says that "our identity is

\footnotetext{
200 Minow, 101 Harv L Rev at 95 (cited in note 127).

210 Sandel, Liberalism and the Limits of Justice at 183 (cited in note 4).

211 Unger, Passion at 88-89 (cited in note 116).

${ }^{212}$ Gergen, The Saturated Self at 6 (cited in note 20).
} 
always partly defined in conversation with others."213 Sandel argues that "community ... describe[s] not just a feeling but a mode of self-understanding partly constitutive of the agent's identity."214 And Michelman describes "a self whose identity and freedom consist, in part, in its capacity for reflexively critical reconsideration ... " "215 For me, this kind of hedging raises an irresistible question: how much is partly? If the individual self is divided between a "real" self and an other-created self, how much is allocated to each part? The connection between the literature's answer to this question and its romanticism seems clear. Writers in the tradition of the situated self think that a lot of the self can be recognized as other-created; skeptics disagree.

These two problems exist not only in the writers I have just mentioned but in my own work in this tradition as well, such as in the previous section of this Article. When I write in this tradition, it feels inescapable to be optimistic about inter-personal or interlocal dialogue-why else would one be trying to further it? Hedging seems equally unavoidable. The extent of people's ability to relate to each other is unknowable-it has to be worked out in practice. It is not surprising, therefore, that much of the criticism of the concept of the situated self is based on these two problems. Critics first attack the romanticism of the situated self: people, they suggest, are more selfish than those who write in the tradition think. People are likely to have different values, ${ }^{216}$ and to be willing to sacrifice the rights of others, ${ }^{217}$ particularly those of minorities. ${ }^{218}$ Besides, some add, no one wants to talk as much as would be necessary to engage in all that dialogue. ${ }^{210}$ The critics then seize on the hedging to re-describe human nature, reducing the degree of romanticism to whatever extent they see fit and substituting

213 Taylor, Philosophy and the Human Sciences (cited in note 12) (emphasis added). See text accompanying note 101 for a larger quote.

224 Sandel, Liberalism and the Limits of Justice at 150 (cited in note 4) (emphasis added and subtracted). See also id at $62,179-83$. The qualification can also be found in Sandel's other work: "certain of our roles are partly constitutive of the persons we are . . . " Michael J. Sandel, Liberalism and Its Critics 5 (NYU, 1984) (emphasis added). 215 Michelman, 97 Yale L J at 1528 (cited in note 108) (emphasis added). See text accompanying note 109 for a larger quote.

${ }_{228}$ See, for example, Kathleen M. Sullivan, Rainbow Republicanism, 97 Yale L J 1713, 1722 (1988).

${ }_{212}$ See, for example, Fallon, 102 Harv L Rev at 1698-99, 1729-33 (cited in note 108).

${ }^{218}$ See, for example, Derrick Bell and Preeta Bansal, The Republican Revival and Racial Politics, 97 Yale L J 1609 (1988).

${ }^{210}$ See, for example, Michael Walzer, A Day in the Life of a Socialist Citizen, in Radical Principles: Reflections of an Unreconstructed Democrat 128 (Basic, 1980). 
self-interest in its place. As a conclusion, many of these critics end up embracing some version of the centered self. 220

It bothers me that my criticism of the concept of the situated self shares as much as it does with that of these critics. Readers of this Article could well find the criticism of romanticism and hedging so compelling that they would reject my entire discussion of the situated self in local government law and end up back where we started. My reaction to my own (and others') romanticism and hedging, however, is the opposite of that of the critics. Instead of attempting to recenter the self in something more "realistically" selfish, it seems to me that the alternative is to decenter the self more than those who espouse the situated self, let alone their critics, propose.

Romanticism and hedging stem from the fact that the situated self is only partly decentered. First of all, a portion of the self seems not to be constituted by others at all. This is the self-defining self that the critics seize upon and emphasize. Moreover, the situated self as a whole remains relatively identifiable, relatively centered. The world seems to be composed of the self and others, with the question being how the two should relate to each other. "Self" and "other" seem to have identifiable content both within the definition of the situated self and within the definition of a person's relationships with outsiders. After all, how else could one tell that the self was "in part" constituted by two different ingredients? And why else would the goal be both romantic (bringing the two ingredients together) and hedged (bringing them together to the extent possible)?

One way to reject simultaneously the romanticism and hedging of the situated self and the critics' retreat to the centered subject, then, would be to adopt a more fully decentered conception of self. This would involve moving beyond giving content to the self as other-directed, as selfish, or as partly both. In the local government context, it would mean a rejection of the organization of local government law in terms of suburb vs. city, us vs. them, inside vs. outside, self vs. other. It would, in short, require us to replace the relatively decentered position of the situated subject with a postmodern sense of self.

${ }^{220}$ See, for example, Sullivan, 97 Yale L J at 1714, 1719-23 (cited in note 216) (arguing for fostering voluntary groups); Fallon, $102 \mathrm{Harv} \mathrm{L}$ Rev at 1725-30 (cited in note 108) (evaluating Michelman's version of republicanism in terms of its effect on private autonomy); Bell and Bansal, 97 Yale $L \mathrm{~J}$ at 1609, 1619-21 (cited in note 218) (suggesting a sharp black/ white distinction in evaluating republicanism). 


\section{The Postmodern SubJect}

\section{A. A Glimpse at the Literature}

An enormous literature extends the critique of the centered subject beyond the notion of the situated self. Considerable differences exist within this literature among aspects labeled poststructuralist, postmodernist, feminist, and critical race theory. ${ }^{221}$ As in Part II, I intend not to survey the work of even a single proponent of any of these strands. Moreover, here, as there, the writers I mention do not add up to a single school of thought; on the contrary, they often not only have different objectives but criticize each other. ${ }^{222}$ Once again, I seek merely to suggest the kinds of ideas that those who write in these traditions advance, all of which readers could make a source of innovation in local government law and only a few of which I have room to discuss below. In Part II, I described the situated subject in terms of a relationship between self and other; here my sketch of the postmodern subject will be presented in terms of a critique of both of these ingredients-a critique of both "self" and "other."

Let us start with a look at the self. Exponents of the situated subject use the term "self" to refer to the individual taken as a whole, although the term could also be used to mean only that part of the situated subject that is self-defining rather than constituted in relationship with others. For the critics of the situated self (and perhaps some proponents as well), this self-defining aspect of the self is the "real" self-the core component that distinguishes an individual from outsiders. For the postmodern subject, there is no

231 See Jane Caplan, Postmodernism, Poststructuralism, and Deconstruction: Notes for Historians, 22 Central European History 260, 262 (Sep/Dec 1989) ("postmodernism, poststructuralism, and deconstruction are not interchangeable synonyms"); Andreas Huyssen, After the Great Divide: Modernism, Mass Culture, Postmodernism 207-16 (Indiana, 1986) (arguing that poststructuralism is modernist not postmodernist); Kwame Anthony Appiah, Is the Post- in Postmodernism the Post- in Postcolonial?, 17 Critical Inquiry 336 (Winter 1991); bell hooks, Postmodern Blackness, in Yearning 23, 23-31 (cited in note 12) (comparing radical black subjectivity with postmodernist forms of identity); Mary Joe Frug, Postmodern Legal Feminism at 10, 53-54, 113-14, 125-27 (cited in note 12) (offering a defnition of postmodern feminism). Compare Hal Foster, Re: Post, in Brian Wallis, ed, Art After Modernism: Rethinking Representation 189, 189-96 (Godine, 1984) ("To an extent . . . the postmodernist line retraces the poststructuralist line ...." Id at 194). For other examples of poststructuralism, postmodernism, feminism and critical race theory, see note 12 .

222 The works that I cite below are part of a series of debates rather than a collective, coherent position. For example, to adopt Matthew Kramer's terminology, poststructuralists tend to discuss metaphysical questions (they investigate the nature of any possible world) while postmodernists investigate mundane questions (they are culture critics, investigating the current state of our own society). See Matthew H. Kramer, God, Greed, and Flesh: Saint Paul, Thomas Hobbes, and the Nature/Nurture Debate; 30 S J Phil 51, 51 (1992). 
such core component. On the contrary, the more one tries to nail down what this core is, the more one realizes that the core is empty, that what seems to be a core is an absence rather than the very center of the self. The postmodern subject has no self that can be separated from otherness.

There are many ways that this postmodern conception of the subject has been articulated, including (among others) psychoanalytic, poststructuralist, and feminist approaches. One ingredient in the psychoanalytic literature, ${ }^{223}$ for example, focuses on the gap that exists, before the acquisition of language, between the fragmented and confused sensations that an infant experiences and a coherent sense of self. An infant desires the focus and coordination of a unified identity, but that is just what $\mathrm{s} / \mathrm{he}$ lacks. The only way for the infant to forge a coherent self out of an experience of a swarm of objects, fantasies, and sensations is to identify with something-like her/his image in the mirror-other than the self. "If I desire to be (an) I, if I desire myself, it must, following elementary logic, be because I am not it. . . . [The] foundation of identity ... does not exist within me: it is elsewhere, in this other."224 But achieving a feeling of oneness with this other-and thus filling this lack of self-can never be accomplished.

The mirror image can no more be assimilated than can any of those other privileged objects [that might fulfill the infant's desire], yet the subject defines itself entirely in relation to it. As a consequence of the irreducible distance which separates the subject from its ideal reflection, it entertains a profoundly ambivalent relationship to that reflection. It loves the coherent identity which the mirror provides. However, because the image remains external to it, it also hates that image. ${ }^{225}$

223 See, for example, Borch-Jacobsen, Freudian Subject (cited in note 12); Lacan, Écrits at 1-7 (cited in note 12); Julia Kristeva, Desire in Language: A Semiotic Approach to Literature and Art 271-91 (Columbia, 1980). Helpful secondary literature includes Kaja Silverman, The Subject of Semiotics 132-93 (Oxford, 1983) (on Freud and Lacan); Fredric Jameson, Imaginary and Symbolic in Lacan: Marxism, Psychoanalytic Criticism, and the Problem of the Subject, in Shoshana Felman, ed, Literature and Psychoanalysis: The Question of Reading: Otherwise 338, 338-95 (Johns Hopkins, 1977) (on Lacan); Jane Gallop, Reading Lacan (Cornell, 1985); Elizabeth Grosz, Sexual Subversions: Three French Feminists 39-69 (Allen and Unwin, 1989) (on Kristeva).

214 Mikkel Borch-Jacobsen, The Freudian Subject, from Politics to Ethics, in Eduardo Cadava, Peter Connor and Jean-Luc Nancy, eds, Who Comes After the Subject? 61, 66 (Routledge, 1991).

${ }^{218}$ Silverman, Subject of Semiotics at 158 (cited in note 223). 
Because the mirror image is a fiction that one can only misrecognize as (one)self-because one can never be such a self-narcissistic desire is permanent, unsatisfiable, abyssal.

Poststructuralists, along with many who follow a psychoanalytic approach, add to this picture the acquisition of language. ${ }^{226}$ Indeed, "add" is the wrong word because the pre-verbal stage of life can only be understood through, and is transformed by, language. ${ }^{227}$ The personal pronoun $I$, like the mirror image, holds out an unattainable promise of unity. $I$ represents all that a person is. But, at the same time, $I$ is a word that, like all words, comes from outside and is subject to a structure of language that the individual neither invents nor controls. The word $I$ participates in an endless, shifting chain of meaning; what it seeks to represent "is never absolutely present outside a system of differences." ${ }^{228}$ As Emile Benveniste points out, the word $I$ is defined in contrast to the word you: "I use $I$ only when I am speaking to someone who will be a you in my address." 228 Moreover, the meanings of these two words are not only opposite but reversible; the referent of $I$ shifts from speaker to speaker depending on who is doing the speaking. In language, " $I$ is nothing but the one who says $I$. ."230

Nevertheless, people constitute themselves as subjects through use of such a word. Subjectivity "is defined not by the feeling which everyone experiences of being himself (this feeling, to the degree that it can be taken note of, is only a reflection) but as the psychic unity that transcends the totality of the actual experiences it assembles and that makes the permanence of the consciousness."231 This assembling of the totality of experience-this forming and transmitting of experience through the word $I$-is "the self." Yet, as each speaker uses the word $I$ "to express himself, . . . the interior 'thing' he claims to 'translate' is itself no more than a ready-made lexicon, whose words can be explained only through other words, and this ad infinitum."2s2 Use of the word $I$ to re-

${ }^{228}$ See, for example, Roland Barthes, The Rustle of Language (Hill \& Wang, 1986); Jacques Derrida, Writing and Difference at 278 (cited in note 4); Michel Foucault, The Order of Things: An Archaeology of the Human Sciences (Random House, 1970); Julia Kristeva, The System and the Speaking Subject, in Toril Moi, ed, The Kristeva Reader 24, 24-33 (Columbia, 1986); Lacan, Ecrits at 146-75 (cited in note 12). 223).

${ }^{227}$ See Jameson, Imaginary and Symbolic in Felman, Literature at 378 (cited in note

${ }^{228}$ Derrida, Writing and Difference at 280 (cited in note 4).

220 Emile Benveniste, Problems in General Linguistics 224 (Miami, 1971).

230 Barthes, Rustle of Language at 51 (cited in note 226).

231 Benveniste, Problems at 224 (cited in note 229).

232 Barthes, Rustle of Language at 53 (cited in note 226). 
present the self thus opens an unbridgeable gap between language and referent, symbol and reality, meaning and being-unbridgeable because the "referent," "reality," and "being" of subjectivity are available to us only through language. ${ }^{233}$ And, in language, the word $I$ can be used by everyone and has an evershifting referent: " $I$ is nothing but the one who says $I . "$ "284

Judith Butler's brilliant book, Gender Trouble, ${ }^{235}$ extends this postmodern conception of the subject to gender, a fundamental aspect of identity (and the body). By understanding the "self" as a fantasy, Butler argues, one can recognize that the acts, gestures, and desires associated with gender do not express an already existing interior essence. People have no interior essence. Instead these acts, gestures and desires are attempts to act out-to inscribe on the surface of the body-an idealized, publicly created image of what gender is.

In what sense . . . is gender an act? As in other ritual social dramas, the action of gender requires a performance that is repeated. This repetition is at once a reenactment and reexperiencing of a set of meanings already socially established; and it is the mundane and ritualized form of their legitimation. Although there are individual bodies that enact these significations by becoming stylized into gendered modes, this "action" is a public action. These are temporal and collective dimensions to these actions, and their public character is not inconsequential; indeed, the performance is effected with the strategic aim of maintaining gender within its binary frame-an aim that cannot be attributed to a subject, but, rather, must be understood to found and consolidate the subject. ${ }^{\text {238 }}$

23s Benveniste, Problems at 224 (cited in note 229); Martin Heidegger, Letter on Humanism, in David Farrell Krell, ed, Basic Writings from Being and Time (1927) to The Task of Thinking (1964) 193 (Harper \& Row, 1977) ("Language is the house of Being. In its home man dwells.").

${ }^{234}$ Barthes, Rustle of Language at 51 (cited in note 226).

238 Butler, Gender Trouble (cited in note 19).

238 Id at 140. For a more extended version of Butler's argument, see id at 134-49. Mikkel Borch-Jacobsen makes a more general argument:

[D]esire has no object, at least not before some mediator-teacher, friend, books, fashion, culture, etc.-intervenes to tell it what is desirable. Thus we must not imagine some essential bond between desire and its object: the desire for an object is a desireeffect; it is induced, or at least secondary, with respect to the imitation-the mimesis - of the desire of others. . . [M] [Mmesis informs desire, directs it, and, more broadly speaking, incites it.

Borch-Jacobsen, Freudian Subject at 26-27 (cited in note 12). 
Butler suggests that the constructed nature of gender can best be understood by examining such overt gender performances as drag and cross-dressing. ${ }^{237}$ Dissecting these performances allows us to recognize the performative nature of all gendered identities while, at the same time, exposing possibilities for reconfiguration, redeployment, and opposition to existing gender norms.

Butler's invocation of the socially constructed nature of the gender system brings us to the second aspect of the postmodern subject, its critique not of the "self" but of "other." The critique to which I am referring ${ }^{238}$ examines the "postmodern condition"-the experience of living in a world without a core sense of self. The situated subject, as sketched above, longs for interconnection with others: $s /$ he seeks the experience of collective unity no matter how difficult (even impossible) it is to achieve. The postmodern subject, by contrast, denies her/himself this solace, this nostalgia for the unattainable, this hope of bringing the mysterious hidden core of the self to the surface and sharing it with others. ${ }^{239}$ For the postmodern subject, relationship with others-and with the world at large-is an experience not of consensus, totality, or oneness but of conflicting multiplicities.

Here, for example, is Jean-Francois Lyotard's description of the postmodern condition:

A self does not amount to much, but no self is an island; each exists in a fabric of relations that is now more complex and mobile than ever before. Young or old, man or woman, rich or poor, a person is always located at "nodal points" of specific communication circuits, however tiny these may be. Or better: one is always located at a post through which various kinds of messages pass. No one, not even the least privileged among us, is ever entirely powerless over the messages that traverse and position him at the post of sender, addressee, or referent. One's mobility in relation to these language game effects (language games, of course, are what this is all about) is tolerable, at least within certain limits (and the limits are vague) .... It may even be said that the system can and must encourage such movement to the extent that it combats its own entropy;

${ }^{237}$ Butler, Gender Trouble at 136-39 (cited in note 19). See generally, Marjorie Garber, Vested Interests: Cross-Dressing \& Cultural Anxiety (Routledge, 1992).

${ }^{238}$ An alternative concoption of "other" is that it is someone else's self. One form of the critique of "other," therefore, would simply repeat what was just said about $I$ and apply it to you.

230 See Lyotard, Postmodern Condition at 81 (cited in note 12). 
the novelty of an unexpected "move," with its correlative displacement of a partner or group of partners, can supply the system with that increased performativity it forever demands and consumes. ${ }^{240}$

This quotation from Lyotard provides a contrasting language to that associated with the situated subject: communication circuits rather than community, language games rather than inter-subjectivity, moves in a system rather than desire.

There are dozens of attempts such as Lyotard's to characterize the postmodern experience. Some writers use the word "pastiche" to describe the experience of recognizing the endless connotations and references invoked by one's own activity. ${ }^{241}$ Everyone knows that his or her actions are understandable only because they can be compared to actions already taken by others; the postmodern subject bases her/his presentation of self on this recognition of inter-textuality and quotation. ${ }^{242}$ In the postmodern world there are no originals, only copies. ${ }^{243}$ (Umberto Eco's oft-quoted postmodern reading of the phrase "I love you madly"-reproduced in the footnote-illustrates this phenomenon.) ${ }^{244}$ The term "schizophrenia" is also widely used in the postmodern literature. For example, Baudrillard says at the end of The Ecstasy of Communication:

[W]ith communication and information, with the immanent promiscuity of all these networks, with their continual connec-

\footnotetext{
240 Id at 15.

${ }^{241}$ See, for example, Fredric Jameson, Postmodernism, or, The Cultural Logic of Late Capitalism 16-25 (Duke, 1991).

${ }^{242}$ According to Fredric Jameson, pastiche is like parody except that it is blank parody, without a satiric impulse: "the imitation of dead styles, speech through all the masks and voices stored up in the imaginary museum of a now global culture." Id at 18. For an alternative view of pastiche-and of associated ideas such as kitsch and retro fashion-see Celeste Olalquiaga, Megalopolis: Contemporary Cultural Sensibilities (Minnesota, 1992). See also Erving Goffman, The Presentation of Self in Everyday Life (Doubleday, 1959).

21s See Rosalind E. Kraus, The Originality of the Avant-Garde, in The Originality of the Avant-Garde and Other Modernist Myths 151 (MIT, 1985).

214 I think of the postmodern attitude as that of a man who loves a very cultivated woman and knows he cannot say to her, "I love you madly," because he knows that she knows (and that she knows that he knows) that these words have already been written by Barbara Cartland. Still, there is a solution. He can say, "As Barbara Cartland would put it, I love you madly." At this point, having avoided false innocence, having said clearly that it is no longer possible to speak innocently, he will nevertheless have said what he wanted to say to the woman: that he loves her, but he loves her in an age of lost innocence.

Umberto Eco, Postscript to The Name of the Rose 67 (Harcourt Brace Jovanovich, 1983). One place Eco's story is quoted is in Jencks, The Post-Modern Reader at 73-74 (cited in note 12); I now quote it again, saying what I have to say by continuing the chain of quotations.
} 
tions, we are now in a new form of schizophrenia. . . . The schizo is bereft of every scene, open to everything in spite of himself, living in the greatest confusion. . . . What characterizes him is less the loss of the real, the light years of estrangement from the real, the pathos of distance and radical separation, as is commonly said: but, very much to the contrary, the absolute proximity, the total instantaneity of things, the feeling of no defense, no retreat. It is the end of interiority and intimacy, the overexposure and transparence of the world which traverses him without obstacle. He can no longer produce the limits of his own being, can no longer play nor stage himself, can no longer produce himself as mirror. He is now only a pure screen, a switching center for all the networks of influence. ${ }^{245}$

Finally-to offer one last example-Brian McHale argues that living in a postmodern world raises not the kind of epistemological questions that might be asked by a situated subject ("How can I interpret this world of which I am a part? And what am I in it?") but ontological questions ("Which world is this? What is to be done in it? Which of my selves is to do it? ... What happens when different kinds of world are placed in confrontation, or when boundaries between worlds are violated?"). ${ }^{246}$ The appropriate literary genre for postmodern literature, he concludes, is not the mystery (as it might be for the situated subject) but science fiction. ${ }^{247}$

How can a person affect-intervene in-a world understood in terms of communication circuits, language games, moves in a system, pastiche, schizophrenia, science fiction? How can there be individual action without a "self?" From the perspective of a situated subject (like a centered subject), individual action is located in the self, and political effectiveness depends on winning others over. For a postmodern subject, by contrast, a situated subject's efforts to build a community does not express her/his inner self but reenacts a performance, a game, a role in a publicly created system. The domain of politics, Michel Foucault argues, lies in ex-

24 Jean Baudrillard, The Ecstasy of Communication, in Hal Foster, ed, The Anti-Aesthetic: Essays on Postmodern Culture 126, 132-33 (Bay, 1983). The term "schizophrenia" is also used (albeit differently) by Jameson, Postmodernism at 25-31 (cited in note 241) (embracing the view that schizophrenia is a breakdown in the signifying chain).

246 Brian McHale, Postmodernist Fiction 9-10 (Methuen, 1987).

${ }^{247} \mathrm{Id}$ at 16. 
amining and challenging the ways in which such a performance, game, or system creates the notion of the individual.

[T] he systematic dissociation of identity . . . is necessary because this rather weak identity, which we attempt to support and to unify under a mask, is in itself only a parody: it is plural; countless spirits dispute its possession; numerous systems intersect and compete. ... [What is required] is to reveal the heterogeneous systems which, masked by the self, inhibit the formation of any form of identity. ${ }^{248}$

No viewpoint allows us to examine current forms of identity by stepping outside them; the power of the heterogeneous systems that form our identities is not an outside force that individuals might resist as an act of will. On the contrary, Foucault contends,

one of the prime effects of power [is] that certain bodies, certain gestures, certain discourses, certain desires come to be identified and constituted as individuals. The individual . . . is not the vis-a-vis of power . . . . The individual is an effect of power, and at the same time, or precisely to the extent to which it is that effect, it is the element of its articulation. ${ }^{\mathbf{2 4 9}}$

Foucault argues that "[w]e have to promote new forms of subjectivity through the refusal of this kind of individuality which has been imposed on us for several centuries."250 Yet such an effort always has the potential of backfiring: it might reproduce, rather than subvert, the kind of identity that one is seeking to contest. ${ }^{251}$ In Lyotard's words, "the system can and must encourage such movement ... [to] increase[] [the] performativity it forever demands and consumes."252

248 Foucault, Language, Counter-Memory, Practice at 161-62 (cited in note 5).

269 Foucault, Power/Knowledge at 98 (cited in note 18).

${ }^{250}$ Michel Foucault, The Subject and Power, in Hubert L. Dreyfus and Paul Rabinow, Michel Foucault: Beyond Structuralism and Hermeneutics 208, 216 (Chicago, 1982). In Judith Butler's words, "[t]he critical task is [] to locate strategies of subversive repetition enabled by [] constructions [of identity], to affirm the local possibilities of intervention through participating in precisely those practices of repetition that constitute identity and, therefore, present the immanent possibility of contesting them." Butler, Gender Trouble at 147 (cited in note 19).

${ }_{2 s 1}$ The postmodern subject cannot avoid the well-known irony that purposive action often promotes just what it seeks to undermine. See Jon Elster, Sour Grapes: Studies in the Subversion of Rationality (Cambridge, 1983); Joel Garreau, Edge City: Life on the New Frontier 42 (Doubleday, 1991) ("The Law of Unintended Consequences").

${ }^{262}$ Lyotard, Postmodern Condition at 15 (cited in note 12). See text accompanying note 240 for a larger quote. 
Whether despite or because of these difficulties, many scholars, such as postmodern feminists and critical race theorists, are currently trying to subvert reigning notions of identity. Thus Angela Harris, citing the work of bell hooks, Patricia Williams, and Zora Neale Hurston, has argued that black women-not uniquely but in poignant and striking ways-have articulated a multiple consciousness, an experience not of "a single inner self (much less one that is essentially gendered), but many selves."25s "[W]e are not born with a 'self," " Harris says, "but rather are composed of a welter of partial, sometimes contradictory, or even antithetical 'selves.' "254 Harris relies on this sense of multiple identity to question dominant conceptions of the subject in feminist theory. Patricia Williams, bell hooks, and Kwame Anthony Appiah, among others, have used a related strategy to challenge the prevailing notions of race. ${ }^{255}$ I now turn, in a similar fashion, to an attempt to subvert the centered subjectivity of local government law.

\section{B. The Postmodern Subject as Local Government Law}

A postmodern conception of local government law must start with a postmodern conception of localities. Part II's version of local government law was based on the notion that cities and suburbs are interrelated rather than separate, independent entities, and it therefore treated those who live in one jurisdiction as constituted, in part, by actions taken by those who live in others. The postmodern version sketched here rejects both Part II's emphasis on residency as the focal point of a person's relationship to the metropolitan area and the city/suburb distinction itself. Instead of envisioning people as located on one side or the other of a city/ suburb line, it builds on the idea that "[y]oung or old, man or wo-

${ }^{253}$ Harris, 42 Stan L Rev at 608 (cited in note 12), citing bell hooks, Talking Back: Thinking Feminist, Thinking Black (South End, 1989); Patricia Williams, On Being the Object of Property, 14 Signs 5 (1988); and Zora Neale Houston, How It Feels to Be Colored $M e$, in Alice Walker, ed, I Love Myself When I Am Laughing 152 (Feminist, 1979).

${ }^{254}$ Harris, 42 Stan L Rev at 584 (cited in note 12).

${ }^{258}$ See, for example, Williams, Alchemy at 9-10 (cited in note 12):

A man with whom I used to work once told me that I made too much of my race. "After all," he said, "I don't even think of you as black." Yet sometime later, when another black woman became engaged in an ultimately unsuccessful tenure battle, he confided to me that he wished the school could find more blacks like me. I felt myself slip in and out of shadow, as I became nonblack for purposes of inclusion and black for purposes of exclusion; I felt the boundaries of my very body manipulated, casually inscribed by definitional demarcations that did not refer to me.

See also bell hooks, Yearning at 15-40 (cited in note 12); Appiah, In My Father's House at 28-46, 173-80 (cited in note 12). 
man, rich or poor, a person is always located at 'nodal points' of specific communication circuits"2se spread throughout the area.

The city/suburb distinction is often used to contrast two images: a congested, dangerous, deteriorating inner city and a quiet, prosperous, residential suburb. ${ }^{257}$ Such a picture misrepresents life in contemporary American metropolitan areas. Parts of America's cities are certainly characterized by congestion, poverty and urban decay, but so are many suburbs. ${ }^{258}$ Indeed, these suburbs are often worse off than inner cities because their property values are so low that they cannot afford even the limited social services that cities offer their poorest residents. Similarly, if we think of a suburb as a homogeneous residential area dominated by well-kept single family houses set in yards, "almost all large cities," as Robert Fishman has noted, "have suburbs . . . within their bor-

${ }^{268}$ Lyotard, Postmodern Condition at 15 (cited in note 12). See text accompanying note 240 for a larger quote.

${ }^{287}$ See, for example, James Q. Wilson, The Contradictions of an Advanced Capitalist State, Forbes 110 (Sep 14, 1992) ("The inner city has always been a haven for criminals who could take advantage of its anonymity, disorder and low-cost housing. . . . What produced the good life for individuals did not produce it for cities. The reason is that prosperity enabled people to move to the kinds of towns Americans have always wanted to live in-small, quiet and nice."). Although Professor Briffault recognizes that this imagery does not reflect American life, see Briffault, 90 Colum L Rev at 353 (cited in note 3), he nonetheless builds his argument on this structure. See, for example, id at 354 (making a homogeneity/diversity distinction); id at 439 (making a work/residence distinction). Others simply take a city/suburb distinction for granted. See, for example, Thomas M. Stanback, Jr., The New Suburbanization: Challenge to the Central City 1-2 (Westview, 1991); Peterson, City Limits at 104 (cited in note 3); Arkes, Philosopher in the City at 320-26 (cited in note 56).

${ }^{258}$ Pierre deVise, of Roosevelt University, has recently completed a study entitled Shifts in the Geography of Wealth and Poverty in Suburban America: 1979 to 1989 (1992) (on file with U Chi L Rev). His analysis of the 1990 Census lists the following as the ten poorest suburbs in the nation:

\begin{tabular}{|c|c|c|c|}
\hline $\begin{array}{c}\text { Low } \\
\text { Income } \\
\text { Rank } \\
1990\end{array}$ & & $\begin{array}{c}\text { Per Capita } \\
\text { Income } \\
1989\end{array}$ & Metro Area \\
\hline 1 & Ford Heights, IL & 4,660 & Chicago \\
\hline 2 & Alorton, ㅍ & 4,846 & St. Louis \\
\hline 3 & Gladeview, FL & 5,339 & Miami \\
\hline 4 & Florence-Graham, CA & 5,407 & Los Angeles \\
\hline 5 & Kinloch, MO & 5,569 & St. Louis \\
\hline 6 & Coachella, CA & 5,760 & Los Angeles \\
\hline 7 & Cudahy, CA & 5,935 & Los Angeles \\
\hline 8 & Bell Gardens, CA & 6,125 & Los Angeles \\
\hline 9 & Goulds, FL & 6,298 & Miami \\
\hline 10 & Brownsville, FL & 6,313 & Miami \\
\hline
\end{tabular}

See id at 21. All but one of these suburbs is more than $90 \%$ black and/or Hispanic (Bell Gardens is $87.5 \%$ Hispanic). See also John McCormick and Peter McKillop, The Other Suburbia, Newsweek 22 (Jun 26, 1989). 
ders."259 These residential areas within cities (Riverdale in New York, West Roxbury in Boston, Chestnut Hill in Philadelphia, Chevy Chase D.C. in Washington, Sauganash in Chicago, Palmer Woods in Detroit, River Oaks in Houston, Sea Cliff in San Francisco) are indistinguishable from neighborhoods on the other side of the city line. Moreover, people of color live in both kinds of neighborhoods. ${ }^{260}$ One-third of African Americans live in middle class suburbs; ${ }^{261}$ in some suburbs a majority of residents are African Americans, Chinese, or Latino. ${ }^{262}$ To be sure, lines of race divide American metropolitan areas as sharply as the Berlin Wall formerly divided Berlin and the green line divided Beirut. But these racial lines are more often found within cities and between suburbs than along the city/suburb boundary (East 96th Street and Howard Beach in New York, South Side and Bridgeport in Chicago, Roxbury and South Boston in Boston, Compton/Watts and the Westside in Los Angeles). ${ }^{263}$ Finally, it is not just the mid-

${ }^{259}$ Fishman, Bourgeois Utopias at 6 (cited in note 8). See also Garreau, Edge City at 149 (cited in note 251); David R. Contosta, Suburb in the City: Chestnut Hill, Philadelphia, 1850-1990 (Ohio State, 1992). Indeed, if we think of suburbanization as "creating the appearance of nonurbanized space," cities are becoming suburbanized while suburbs are becoming urbanized. Joseph S. Wood, Suburbanization of Center City, 87 The Geographical Rev 325, 326 (Jul 1988).

260 There are prosperous black neighborhoods both within the city (Baldwin Hills in Los Angeles, South Shore in Chicago, West Mount Airy in Philadelphia) and outside the city limits (Rolling Oaks in Dade County, Brook Glenn near Atlanta, Prince George's County near Washington, D.C.). Garreau, Edge City at 143-78 (cited in note 251) (on Atlanta); David J. Dent, The New Black Suburbs, NY Times Mag 18, 20 (Jun 14, 1992) (on Prince George's County). And, as just noted, there are poor black neighborhoods in the suburbs as well as in the cities. See deVise, Shifts (cited in note 258). The same diversity exists for Hispanics: there are prosperous (Laurel Heights in San Antonio, the Coronado area in EI Paso) and poor (Los Jardines in San Antonio, the downtown area in El Paso) Hispanic neighborhoods inside the same city. CACI Marketing Systems, Source Book of ZIP Code Demographics 317-18 C-D, 324 C-D (CACI, Census ed, 1992). And there are prosperous and poor Hispanic neighborhoods in the suburbs as well. Denise Hamilton, The Changing Face of the San Gabriel Valley, LA Times J1, col 2 (Oct 25, 1992) (11 of the 34 cities and unincorporated communities in the San Gabriel Valley, near Los Angeles, have Hispanic majorities); deVise, Shifts (cited in note 258).

${ }^{281}$ Garreau, Edge City at 150 (cited in note 251); Dent, NY Times Mag at 20 (cited in note 260).

${ }^{282}$ For example, Prince George's County near Washington; Brook Glen, Panola Mill, and Wyndham Park near Atlanta; Alorton near St. Louis; and Ford Heights near Chicago are majority African American. Dent, NY Times Mag at 20 (cited in note 260); deVise, Shifts at 21 (cited in note 258). Monterey Park, California is majority Chinese. Mike Davis, City of Quartz: Excavating the Future in Los Angeles 207 (Verso, 1990). And, like many other suburbs, see CACI, Source Book at 317-18 C-D, 324 C-D (cited in note 260), Pomona and East Los Angeles, California are majority Latino. Hamilton, LA Times at J1, col 2 (cited in note 260); deVise, Shifts at 21 (cited in note 258).

${ }^{283}$ See Ford, 9 Harv Blackletter $J$ at 139-45 (cited in note 23); Paul Virilio, The Overexposed City, in Jonathan Crary, et al, eds, Zone 1/2: The Contemporary City 15 (Urzone, 
dle-class and the underclass who live on both sides of the border: there are working-class suburbs just as there are working-class neighborhoods within cities. ${ }^{284}$

The other characteristic that has traditionally been associated with cities-a central business district with offices and stores-similarly describes suburbs as well as cities. ${ }^{265}$ "Most large metropolitan areas have ten to thirty urban cores, the downtown being just one of them." ${ }^{286}$ Two-thirds of American offices are currently located outside of city downtowns. ${ }^{267}$ Tyson's Corner, Virginia has more office space than downtown Miami; ${ }^{268}$ Southfield, Michigan has more office space than Detroit. ${ }^{269}$ "By 1980, 38 percent of the nation's workers commuted to their jobs from suburbto-suburb, while only half as many made the stereotypical suburbto-city trek."270 Moreover, shopping malls have not only brought the density and feel of city commercial life to the suburbs but suburban stores now outsell their city competitors. ${ }^{271}$ Some of these suburban malls are as big as city downtowns. (On Route 202 in King of Prussia, Pennsylvania, the sign reads: "MALL NEXT

1986) (Zone is a series of books published irregularly by Urzone, Inc. of New York City and distributed by the Johns Hopkins University Press, Baltimore, Maryland.).

${ }^{204}$ See, for example, Bennett M. Berger, Working-Class Suburb: A Study of Auto Workers in Suburbia (California, 1960) (about Richmond, California).

${ }^{208}$ Joel Garreau has invented a new term, "Edge City," to describe areas, overwhelmingly residential or rural 30 years ago, which now are single-end destinations for jobs, shopping, and entertainment. To qualify as an Edge City, Garreau insists that the area have at least five million square feet of office space, at least 600,000 square feet of retail space, and a population that increases during the work day ("more jobs than bedrooms"). Garreau, Edge City at 6-7, 425 (cited in note 251). For a list of more than a hundred such Edge Cities in suburbs across the nation, see id at 425-39. See also Robert Fishman, America's New City: Megalopolis Unbound, 14 Wilson Q 24 (Winter 1990) (arguing that suburbs are becoming more and more similar to traditional cities).

${ }^{268}$ Christopher Leinberger, Business Flees to the Urban Fringe, The Nation 10, 11 (Jul $6,1992)$.

${ }^{267}$ Garreau, Edge City at 5 (cited in note 251). Indeed, there is even an increasing number of vacant office buildings in the suburbs, as corporate headquarters move on or cut back. See Thomas Lueck, Vacated Corporate Headquarters Scatter the Suburban Landscape, NY Times A1 (Dec 7, 1992).

${ }^{288}$ Fishman, 14 Wilson $Q$ at 28 (cited in note 265).

${ }^{269}$ James E. Vance, Jr., The Continuing City: Urban Morphology in Western Civilization 506 (Johns Hopkins, 1990).

${ }^{270}$ Fishman, 14 Wilson Q at 27 (cited in note 265).

${ }^{271}$ US Bureau of Census, 1987 Census of Retail Trade: Special Report Series, Selected Statistics Table 5 (GPO, Jan 1991). Nationwide percentages in 1987 were $37 \%$ central city, 45\% suburban. But in many major metropolitan areas the disparity is even greater (Boston: $31.6 \%$ city, $68.4 \%$ suburban; New York: $36.3 \%$ city, $63.7 \%$ suburban; Chicago: $32.6 \%$ city, $67.4 \%$ suburban; Los Angeles: $37.8 \%$ city, $62.2 \%$ suburban). Id. 
FOUR LEFTS.") ${ }^{272}$ The aggregation of restaurants, entertainment, shopping, and pedestrian walkways in suburban shopping malls has, in fact, so captured the image of America's commercial life that cities have begun to restructure their own commercial areas by copying them (Quincy Market in Boston; the Inner Harbor in Baltimore; Watertower Place in Chicago; the Skyways in Minneapolis; Ghirardelli Square in San Francisco; pedestrian zones everywhere). ${ }^{273}$

In sum, in the words of the urban historian James Vance, "[t]oday it is hard to draw a significant concrete distinction between a Clayton and a St. Louis."274 Except, of course, that most of us have never heard of Clayton. The only difference between St. Louis and Clayton is a legal distinction-local government law treats these two parts of the same region as separate and independent sovereignties. ${ }^{275}$ Indeed, during the course of my argument that the city/suburb distinction no longer describes American metropolitan areas, I have repeatedly invoked this legal distinction myself. I have used the words "city" and "suburb" to refer to one side or the other of the invisible line that marks the legally-recognized boundary between them. My use of these terms has masked the pluralism and heterogeneity on both sides of the line. The terms thus have had the characteristics of the term $I$ in the creation of subjectivity: the unity that "city" and "suburb" has assembled has been a unity of (legal) language. As Foucault suggests, use of this language is the exercise of power: the current identities of cities and suburbs are "an effect of power, and at the same time, or precisely to the extent to which ... [they are] that effect ... [they

${ }^{272}$ Garreau, Edge City at 7 (cited in note 251). See also Eric Hubler, Four Million Square Feet of Mall, NY Times sec 5, p 33 (Oct 25, 1992) (on the Mall of America in Bloomington, Minnesota).

${ }^{273}$ See Margaret Crawford, The World in a Shopping Mall, in Sorkin, Variations on a Theme Park 3, 22-30 (cited in note 141); Trevor Body, Underground and Overhead: Building the Analogous City, in Sorkin, ed, Variations on a Theme Park at 123, 136 (cited in note 141) (on Minneapolis skyways); Hall, Cities of Tomorrow at 350 (cited in note 172) (on the influence of James Rouse on American cities). Even city cultural life is increasingly suburban, not urban, in style. See, for example, Edward Rothstein, Cities March to Different Drummers, NY Times, H28, col 4 (Nov 15, 1992) ("Concert halls . . are increasingly catering to suburban audiences; the halls also seem irrelevant to their surrounding, largely black, communities.").

${ }^{274}$ Vance, Continuing City at 508 (cited in note 269). Clayton is the county seat of St. Louis County which surrounds, but does not include, the city. Id at 484 .

${ }^{275}$ See Weiher, Fractured Metropolis at 47-50 (cited in note 141). See also text accompanying notes 140-46. 
are] the element of its articulation."276 To promote an alternative to this form of power, we must start by recognizing the arbitrariness of the city/suburb lines that now fracture America's metropolitan areas. We must look at our metropolitan areas anew, without focusing on the legally recognized borders between localities.

Most Americans who live in these areas already disregard jurisdictional boundaries. Instead of sharply dividing city and suburb, residents create their own idea of the region in which they live by organizing it in terms of the places they know. ${ }^{277}$ They think nothing of crossing city lines for child care, work, shopping, recreation, entertainment, visiting friends, and the like. Their relevant space is "defined by the locations they can conveniently reach in their cars."278 They often do not even know the name of the town where the mall they shop in is located; all they need to know is the name of the mall. Areas that do have names are commonly identified in a way that ignores local government boundaries: Route 128 in Massachusetts, Silicon Valley in Northern California, King of Prussia in Eastern Pennsylvania, the Galleria in Houston, Tyson's Corner in Virginia. ${ }^{279}$ Other areas both in the city and the suburbs-even some close by-are so unfamiliar that people get lost if they try to go there. The metropolitan area as a whole is a hodgepodge of elements-shopping/office/hotel complexes, strip shopping malls, industrial parks, office buildings, department stores, neighborhoods, subdivisions, condominium communities - that is "impossible to comprehend,"280 "vertigo-inducing." For many Americans the symbol of this contemporary form of metropolis is Los Angeles. And, as Joel Garreau reports, "[e]very single American city that is growing, is growing in the fashion of Los Angeles, with multiple urban cores." ${ }^{282}$

278 Foucault, Power/Knowledge at 98 (cited in note 18). See text accompanying note 249 for a larger quote.

${ }_{277}$ See generally, Kevin Lynch, The Image of the City (MIT, 1960).

${ }^{278}$ Fishman, Bourgeois Utopias at 185 (cited in note 8); Jackson, Crabgrass Frontier at 246-71 (cited in note 10) ("The Drive-in Culture of Contemporary America"). Compare Fishman, Bourgeois Utopias at 192 ("a fully developed highway grid eliminates the primacy of the central business district"), with Jackson, Crabgrass Frontier at 270 ("motorcars ... created the demand for more highways, which in turn increased the need for more vehicles, and so on ad infinitum"), with David Rieff, Los Angeles: Capital of the Third World 37 (Touchstone, 1991) (freeways are "the place where [Angelenos] spend the two calmest and most rewarding hours of their daily lives").

${ }^{270}$ See, for example, Langdon Winner, Silicon Valley Mystery House, in Sorkin, ed, Variations on a Theme Park 31, 31-60 (cited in note 141).

${ }^{280}$ Fishman, Bourgeois Utopias at 203 (cited in note 8).

${ }^{281}$ Garreau, Edge City at 8 (cited in note 251).

${ }^{282}$ Id at 3 (emphasis deleted). 
This reference to Los Angeles suggests more than simply the absence of a metropolitan center. ${ }^{283}$ Los Angeles symbolizes another feature of contemporary urban life as well: issues of ethnicity, race, and class cross-cut America's metropolitan areas without stopping at jurisdictional borders. Los Angeles has aptly been labeled the capital of the third world: immigrants from El Salvador, Guatemala, Mexico, the Philippines, Korea, Thailand, Vietnam, Iran, India, Pakistan, Armenia, Russia, and Israel (among other places) have formed communities in the area in both the city and the suburbs. ${ }^{284}$ Similar communities are being created across America. This influx of immigrants has not merely changed the character of the neighborhoods where the immigrants reside. As in Los Angeles, many immigrants do business in the region's poorest neighborhoods (Korean and Latino stores in African American neighborhoods); others work in minimum-wage jobs in the area's shopping/office/hotel complexes; still others spend most of their time in the region's fanciest neighborhoods because they have come to serve as the indispensable maids and babysitters for the upper-middle-class. ${ }^{285}$ Los Angeles is also famous these days as the site of recent riots and of gang warfare in its South Central neighborhoods. Fears of this kind of urban unrest and gang violence have increased throughout the country, ${ }^{286}$ and the proximity between the neighborhoods where the civil unrest and violence have occurred (or threaten to occur) and other neighborhoods has increased with the extent of this fear. Neighborhoods close by were once virtually forgotten ("no one lives in Detroit," someone who lived in a nearby suburb once informed me); ${ }^{28 z}$ now, they seem all too close.

${ }^{283}$ The literature on Los Angeles is immense and growing. See, for example, Davis, City of Quartz (cited in note 262); Rieff, Capital of the Third World (cited in note 278); Edward W. Soja, Postmodern Geographies: The Reassertion of Space in Critical Theory 190-248 (Verso, 1989); Kevin Starr, Inventing the Dream: California Through the Progressive Era (Oxford, 1985).

284 Rieff, Capital of the Third World at 114-47 (cited in note 278). In the Los Angeles school district alone 82 languages are spoken. Id at 105. See also Hamilton, LA Times at J1 (cited in note 260); Jack Miles, Blacks v. Browns; African Americans and Latinos, The Atlantic 41 (Oct 1992); Bill Stall, Assembly Elections 46th District: Diversity Highlights "The Ellis Island of California," LA Times B1 (May 14, 1991).

${ }^{285}$ See Rieff, Capital of the Third World at 81-93 (cited in note 278).

${ }_{286}$ See, for example, John Ellement, More Deadly Violence in Boston, Boston Globe B1 (Oct 8, 1992) (second gang-related murder in a week in Roxbury).

287 See also Rieff, Capital of the Third World at 171-72 (cited in note 278) ("everyone in L.A. is writing a script"); Sara Rimer, Los Angeles Journal: A Crowded Bus that "Nobody Rides," NY Times, A10 (Jul 7, 1992) ("[n]obody rides the bus" in Los Angeles) (reporting that 1.3 million passengers use buses daily). 
As early as 1923, Frank Lloyd Wright declared that "[t]he big city is no longer modern."28s $\mathrm{He}$ was right: as Garreau points out, "we have not built a single old-style downtown from raw dirt in seventy-five years." ${ }^{288}$ It is harder to realize-but it is also true-that the suburban era, the era of lawns and cul-de-sacs, has reached its end as well. ${ }^{290} \mathrm{Now}$, as Michael Sorkin argues, people live in "a wholly new kind of city, a city without a place attached to it," one that Sorkin calls the "ageographical city."201 Sorkin uses the term to describe the pastiche of highways, skyscrapers, malls, housing developments, and chain stores-the endless urban landscape of copies without an original-that constitute the place-bites (the spatial equivalent of sound-bites) of modern America. These place-bites can be combined in an infinite variety of ways, each of which makes equal sense, to represent the metropolitan area. The ageographical city, Sorkin suggests, is the urban form of the 800number: the area code for no-place-in-particular. ${ }^{292}$ To frame local government law in terms of the postmodern subject, we must locate it in this ageographical city.

Local government law, however, now gives priority to a single place-bite within the metropolitan area: the place where people

2ss Quoted in Fishman, 14 Wilson $Q$ at 26 (cited in note 265).

289 Garreau, Edge City at 25 (cited in note 251).

${ }^{200}$ See Fishman, Bourgeois Utopias at 182-207 (cited in note 8); Jackson, Crabgrass Frontier at 296-305 (cited in note 10). Robert Fishman sees the lawn as the classic suburban symbol:

The front lawn is not family space, and family members rarely venture out into it except to maintain it. It belongs, rather, to the community. The lawns, in conjunction with the roadside trees, create the illusion of a park. . . . The lawn is the owner's principle contribution to the suburban landscape-the piece of the "park" he keeps up himself. At the same time the lawn is also a private space, which no casual sidewalk passerby can make his own. It insulates the house while helping to create the green world of the landscape. Not surprisingly, lawn maintenance is considered a civic duty at least as important as any other form of morality. The lawn thus maintains that balance of the public and the private which is the essence of the mature suburban style.

Bougeois Utopias at 146-47 (cited in note 8). Kenneth Jackson offers, instead, the winding lane:

Just as the grid was ideal for the row house, the undulating pattern was best suited to the suburban cottage ... [A] gentle turn was indicative of the pastoral and bucolic pace of the home rather than the busy and efficient system of the office or factory.... [T] he image of the bending road-not a short cut, not a thoroughfare, not a commercial strip, not a numbered street-was part and parcel of the suburban ideal. It offered the aesthetic order of unified design rather than the mechanistic order imposed by grid subdivision.

Crabgrass Frontier at 76 (cited in note 10). For an analysis of the impact of the grid on city life, see Sennett, Conscience of the Eye at 46-62, 214-24 (cited in note 146).

${ }^{291}$ Sorkin, ed, Variations on a Theme Park at xi (cited in note 141).

292 Id. 
live. Indeed, residency has always been at the center of local government law's conception of people's relationship to the space around them. ${ }^{293}$ Perhaps this emphasis on residency was justifiable when, once upon a time, home, work, family, friends, market, past, present, and future were (so we imagine) linked together in one community. But these days some people do not even live at their place of residence: students who spend full-time out-of-state, people who are serving in the military, and business-people who are assigned abroad are all residents of the town they are never in. And those who do live in the area are not found solely at home. Most people spend most of their day in other parts of the region. If the neighborhood where people work deteriorates or their mall closes down, it would affect their lives just as much as an event three blocks away from their residence. In an era when people often do not even know the names of neighbors who live a block away, a person's territorial identity should not be reduced to his or her address.

By locating people in their houses or apartments, local government law romanticizes the home as a haven in a heartless world. ${ }^{294}$ But in contemporary America one's place of residence provides "no defense, no retreat .... [T] he overexposure and transparence of the world which traverses ... [people] without obstacle"285 leaves only a weak sense of "home." The ageographical city is, in other words, the urban form not just of the 800-number but also of the 700-number-the telephone number that is yours regardless of where you live. The average American moves twelve times in a lifetime. ${ }^{286}$ I was born and went to school in Berkeley, California; I met and married my wife (who was from St. Joseph, Missouri) in Washington, D.C.; our son was born in New York City; our daughter was born in Philadelphia; most recent family vacations have been taken in the same house in Westport, Massachusetts; I now live in Cambridge, Massachusetts. Where am I from? Where are you from? Most people recognize that the millions of new immigrants in our metropolitan areas are fractured by attachments to their country of origin, their current neighborhood, the place where they work, and the place where they hope to move-feeling "at

\footnotetext{
${ }^{293}$ Even cases like $M t$. Laurel still retain the idea that residents, and only residents, constitute a city's population. See text accompanying notes 153-60.

294 'The phrase is Christopher Lasch's. See Christopher Lasch, Haven in a Heartless World: The Family Besieged (Basic, 1977).

285 Baudrillard, Ecstasy of Communication at 133 (cited in note 245). See text accompanying note 245 for a larger quote.

${ }^{200}$ Renee Loth, Mustering Up to Move, Boston Globe Mag 10 (Aug 11, 1991).
} 
home" in none of these locations. But in the age of the jet plane, the modem, the fax machine, satellite disks, and USA Today, it is not just recent immigrants who feel more linked to areas far away than close to home. ${ }^{287}$ Someone in the upper-middle-class in Boston is likely to be more connected to, and know more about, midtown Manhattan than Medford.

Of course, many people still feel an attachment to their neighborhood. Sometimes this attachment is linked with commonalities of race, ethnicity, or class; sometimes it is attributed to the fact that a family has lived in the same community for generations; sometimes it is expressed in terms of maintaining property values; sometimes it is expressed as a negative-residents feel trapped, by poverty and exclusion, in an area from which they cannot escape. But local government law has never given legal protection to neighborhoods. On the contrary, recent developments in local government law have presided over the destruction of many neighborhoods to which people have felt connected. ${ }^{288}$ In the 1960 s and 1970 s, some reformers sought to recenter local government law's sense of place from the city or suburb to the neighborhood. ${ }^{290}$ They wanted neighborhood to play the role for territorial identity that biology has played for racial and gender identity - to be the common core that unites the group. But a postmodern reading suggests that, like the reliance on biology (and like the mirror image of the self), ${ }^{300}$ the concept of neighborhood provides no stable basis for either personal or group identity.

The image of neighborhood conjures up the ideal of community, but it is a fantasy community-a (comm) unity that is never achievable. One can succeed in maintaining an inside/outside dis-

297 See Virilio, Zone $1 / 2$ at 23 (cited in note 263) ("With the intense acceleration of telecommunications, the old city disappears, only to give birth to a new form of concentration: the concentration of residentialization without residence, in which property lines, enclosures and partitions are no longer the result of permanent physical obstacles but of interruption of an emission or of an electronic shadow zone which mimics sunshine and the shadows of buildings.").

198 See Poletown Neighborhood Council v City of Detroit, 410 Mich 616, 304 NW2d 455 (1981); Caro, The Power Broker at 850-77 (cited in note 192); Jane Jacobs, The Death and Life of Great American Cities (Random House, 1961).

"see, for example, David Morris and Karl Hess, Neighborhood Power: The New Localism (Beacon, 1975); Milton Kotler, Neighborhood Government: The Local Foundations of Political Life (Bobbs-Merrill, 1969).

200 For a critique of biological essentialism, see, for example, Appiah, In My Father's House at 28-46 (cited in note 12) (race); Butler, Gender Trouble at 1-34 (cited in note 19) (gender); Rist, The Nation 424 (cited in note 25) (sexual orientation). For a critique of the mirror image of the self, see text accompanying notes 223-50; Richard Rorty, Philosophy and the Mirror of Nature (Princeton, 1979). 
tinction that delimits a neighborhood only by failing to see people who are there but do not fit in. Property owners who own property in the area but rent it to others, workers who spend more hours in the area than residents, residents whose violence or addiction threaten neighborhood stability, the homeless who live on the street, part-time residents who spend much of the year elsewhere, maids who "live in," undocumented aliens living with family members-which of these are included in the sense of "neighborhood?" Some local people have always been treated as outside the definition of the community, ${ }^{301}$ while outsiders have often been included as community members. ${ }^{302}$ Even the definition of a neighborhood is contestable: people who have lived in a neighborhood for years often disagree about its borders. ${ }^{303}$ Attachment to a neighborhood, like the maintenance of the gender system, is a "ritual social drama[] ... a performance that . . . is at once a reenactment and reexperiencing of a set of meanings already socially established ... [a performance that] is effected with the strategic aim of maintaining ... [the neighborhood] within its binary [inside/outside] frame." ${ }^{\text {"S04 }}$ Such a performance is constantly jeopardized by aspects of the ageographical city that people in the area cannot avoid or even find attractive.

so1 For a discussion of examples-such as Athenian metics and European guest workers-see Michael Walzer, Spheres of Justice: A Defense of Pluralism and Equality 52-61 (Basic, 1983).

${ }^{302}$ The classical city included as citizens people who lived part-time, or even continuously, outside the walls. The process of periodically collecting all citizens into the city-called "synoecism"-was understood as building an intimate tie between city and countryside. See Vance, Continuing City at 57, 73 (cited in note 269). Even today cities frequently exercise power over people who live outside city borders, although now these outsiders are not citizens. See Comment, The Constitutionality of the Exercise of Extraterritorial Powers by Municipalities, 45 U Chi L Rev 151 (1977); Frank S. Sengstock, Extraterritorial Powers in the Metropolitan Area (Michigan, 1962); Russell Webber Maddox, Extraterritorial Powers of Municipalities in the United States (Oregon State, 1955). The practice of regulating outsiders without treating them as citizens was held constitutional in Holt Civic Club v City of Tuscaloosa, 439 US 60, 65-75 (1978). Finally, some residents of ethnic neighborhoods might consider friends and relatives who live elsewhere to be part of their community. For example, Koreans might be included as part of Koreatown simply on the grounds of their ethnicity-despite the fact that a majority of the residents of Koreatown, at least in Los Angeles, are Latino. Miles, The Atlantic at 52 (cited in note 284).

${ }^{30}$ See, for example, Weiher, Fractured Metropolis at 44 (cited in note 141). The definition of a neighborhood may expand or contract depending on who is asking. When challenged by a rival gangbanger, a person's neighborhood might be defined in terms of a block; when asked by someone from Manhattan Beach, the neighborhood might be thought of as "Compton"; when asked by a New Yorker "where are you from?" $\mathrm{s} / \mathrm{he}$ might well respond "L.A."

304 Butler, Gender Trouble at 140 (cited in note 19). See text accompanying note 236 for a larger quote. 
To replace our current legal conception of localities with one that embraces the ageographical city, we have to stop building local government law on residency and on the importance of local jurisdictional boundaries. We must treat people not as located solely in one jurisdiction but as "switching center[s] for all the networks of influence" 305 within the region that affect their lives. Under current law, residency within city limits determines people's legal rights on issues ranging from voting to their entitlement to participate in government programs. And the location of property within city limits determines who pays for these government programs through the property tax, still the predominant source of local government revenue. ${ }^{306}$ To illustrate how embracing the postmodern subject would transform local government law, I turn to a discussion of two specific local government doctrines: one dealing with residency (eligibility for government services) and one with the property tax (school financing).

Many local services are now available only to the people inside specified jurisdictional borders. School attendance requires living within the school district; police and fire protection stop at the city line; city hospitals exclude non-residents. ${ }^{307}$ One justification offered for these policies analogizes local government services to property rights: only those who pay for services are entitled to receive them. This seems to be the rationale, for example, of Buse $v$ Smith: ${ }^{308}$ locally-raised money should be spent locally, not on outsiders. But those who pay for local services are not the same people as those eligible to receive them. Non-residents who own property in the city pay the property tax, but they cannot send their children to city schools or use city hospitals. ${ }^{309}$ On the other hand, residents who own no property and therefore do not pay property

\footnotetext{
sos Baudrillard, Ecstasy of Communication at 133 (cited in note 245). See text accompanying note 245 for a larger quote.

${ }^{306}$ In Holt, the Court, in holding extraterritorial regulation constitutional, emphasized that the city did not seek to impose a property tax on property located outside city lines. 439 US at $72-73 \mathrm{n} 8$.

${ }_{307}$ See, for example, Martinez $v$ Bynum, 461 US 321, 325-33 (1983) (schools); Baldwin $\checkmark$ Fish and Game Commission, 436 US 371, 378-91 (1978) (hunting); McCarthy v Philadelphia Civil Service Commission, 424 US 645 (1976) (public employment); Memorial Hospital $\checkmark$ Maricopa County, 415 US 250, 255, 267 (1974) (hospitals). See generally Neuman, 135 U $\mathrm{Pa}$ L Rev at 267-70, 301-09 (cited in note 3). Of course services do not have to be limited to residents; when state law permits, some cities allow non-residents to use their services for a fee.

sos 247 NW2d 141, 150-52 (Wis 1976). See text accompanying notes 40-41.

${ }^{309}$ Similarly, non-residents who commute into the city to work pay the income tax, and non-residents who are consumers pay the sales tax, but those payments also do not allow these taxpayers to use city services.
} 
taxes (at least directly) can use city services. Moreover, many city services are supported by state and federal as well as locally-generated revenue. Yet residency remains a qualification for services no matter where the funding comes from. The reason that services are allocated only to residents is not the source of financing but the equation of residency and decentralization: local control means control by residents. ${ }^{310}$

A local government law organized in terms of the postmodern subject would recognize that the maids who clean the residents' houses, the grocery store family that provides their milk, and the consumers who drive to the area to shop are also connected to a neighborhood. Even Justice Rehnquist, in Holt Civic Club $v$ City of Tuscaloosa, ${ }^{311}$ has acknowledged that decisions made by city residents have an impact on nonresidents whether or not the nonresidents enter the city.

The granting of building permits for high rise apartments, industrial plants, and the like on the city's fringe unavoidably contributes to problems of traffic congestion, school districting, and law enforcement immediately outside the city. A rate change in the city's sales or ad valorem tax could well have a significant impact on retailers and property values in areas bordering the city. The condemnation of real property on the city's edge for construction of a municipal garbage dump or waste treatment plant would have obvious implications for neighboring nonresidents. Indeed, the indirect extraterritorial effects of many purely internal municipal actions could conceivably have a heavier impact on surrounding environs than ... .direct regulation ....".\$12

To be sure, Justice Rehnquist used this analysis to defend a residency requirement, not to attack it. " $[N]$ o one," he concluded, "would suggest that nonresidents likely to be affected by this sort of municipal action have a constitutional right to participate in the political processes bringing it about." ${ }^{\prime 13}$ Well, I'm suggesting something of this sort, albeit not on constitutional grounds. In the ageographical city, residency within invisible boundary lines should not determine who can use schools, hospitals, addiction treatment cen-

\footnotetext{
${ }^{320}$ See, for example, Martinez $v$ Bynum, 461 US at 328-30.

312439 US 60 (1978).

${ }^{312}$ Id at 69. For a reading of Justice Rehnquist's opinion from the perspective of the situated self, see Frank I. Michelman, Conceptions of Democracy in American Constitutional Argument: Voting Rights, $41 \mathrm{Fla} \mathrm{L} \mathrm{Rev} \mathrm{443,} \mathrm{472-80} \mathrm{(1989).}$

${ }^{313} 439$ US at 69.
} 
ters or the like. Local services should be open to all local people. The problem is to decide who they are and how to do so; some possibilities are discussed below, in Section C.

Building local government law on a postmodern subjectivity would similarly transform local government financing. At present, only property located within jurisdictional boundaries is subject to tax, and only people who live within the same boundaries benefit from the tax. School financing provides the best known example of the impact of this inside/outside distinction. The Texas Supreme Court's description of the effect of jurisdictional wealth differences in that state is illustrative:

Because of the disparities in district property wealth, spending per student varies widely, ranging from $\$ 2,112$ to $\$ 19,333$. Under the existing system, an average of $\$ 2,000$ more per year is spent on each of the 150,000 students in the wealthiest districts than is spent on the 150,000 students in the poorest districts. The lower expenditures in the property-poor districts are not the result of lack of tax effort. Generally, the property-rich districts can tax low and spend high while the property-poor districts must tax high merely to spend low. In $1985-86$, local tax rates ranged from $\$ .09$ to $\$ 1.55$ per $\$ 100$ valuation. The 100 poorest districts had an average rate of 74.5 cents and spent an average of $\$ 2,978$ per student. The 100 wealthiest districts had an average tax rate of 47 cents and spent an average of $\$ 7,233 .{ }^{314}$

In the celebrated case of San Antonio Independent School District $v$ Rodriguez, the United States Supreme Court rejected an argument that disparities such as these violated the Equal Protection Clause on the grounds that a property-based system enhanced local control, which it defined in classic centered-subject language. ${ }^{315}$ State supreme courts, by contrast, have been divided on the question whether property-based school financing systems violated state constitutions. ${ }^{316}$ But even those state courts that have

${ }^{314}$ Edgewood Independent School District v Kirby, 777 SW2d 391, 392-93 (Tex 1989). 316

In part, local control means ... the freedom to devote more money to the education of one's children. Equally important, however, is the opportunity it offers for participation in the decisionmaking process that determines how those local tax dollars will be spent. Each locality is free to tailor local programs to local needs.

411 US 1, 49-50 (1973). The school district under attack in Rodriguez was the same as the one challenged in Kirby, the Edgewood Independent School District.

316 Cases that have declared school financing systems unconstitutional include DuPree v Alma School District No 30, 279 Ark 340, 651 SW2d 90, 91-92 (1983); Serrano v Priest, 5 
held school financing systems unconstitutional have continued to recognize the importance of boundary lines. The Texas Supreme Court, for example, has made clear that its decision to invalidate the state's school financing system does not require localities to educate people who live outside their borders. And, the court indicated, once the state adds enough money to the system to ensure that there is an efficient system of public schools throughout the state, school districts will be able to supplement the education of their residents through locally raised property taxes. ${ }^{317}$ Other state courts have similarly permitted this kind of local supplementation, thereby perpetuating the idea that the property located inside jurisdictional borders exists for the benefit of residents. ${ }^{318}$

By defining the tax base in terms of the property found within a jurisdiction and by defining the beneficiaries of the tax base in terms of residency, local government law creates and intensifies inequality within the metropolitan area. ${ }^{319}$ It's no accident that the

Cal 3d 584, 96 Cal Rptr 601, 487 P2d 1241 (1971); Horton v Meskill, 172 Conn 615, 376 A2d 359, 374-75 (1977); Rose $v$ Council for Better Educ., 790 SW2d 186 (Ky 1989); Helena Elementary School v State, 236 Mont 44, 769 P2d 684 (1989); Abbott v Burke, 119 NJ 287, 575 A2d 359 (1990); Carrollton-Farmers Branch Independent School District v Edgewood Independent School District, 826 SW2d 489, 500-14 (Tex 1992); Seattle School District No $1 v$ State, 90 Wash 2d 476, 585 P2d 71, 76-77 (1978); Pauley v Kelly, $162 \mathrm{~W}$ Va 672, 255 SE2d 859 (1979); Washakie County School District v Herschler, 606 P2d 310 (Wyo 1980). Those that have rejected constitutional challenges include Shofstall $v$ Hollins, 110 Ariz 88, 515 P2d 590 (1973); Lujan v Colorado State Bd. of Educ., 649 P2d 1005 (Colo 1982); Thompson $v$ Engelking, 96 Idaho 793, 537 P2d 635 (1975); Hornbeck v Somerset County Bd. of Education, 295 Md 597, 458 A2d 758 (1983); Board of Education, Levittown Union Free School Dist. v Nyquist, 57 NY2d 27, 453 NYS2d 643, 439 NE2d 359 (1982); Board of Education $v$ Walter, 58 Ohio St 2d 368, 390 NE2d 813 (1979); Fair School Finance Council v State, 746 P2d 1135 (Okla 1987); Olsen v State, 276 Or 9, 554 P2d 139 (1976); Danson v Casey, 484 Pa 415, 399 A2d 360 (1979); Kukor $v$ Grover, 148 Wis 2d 469, 436 NW2d 568 (1989). The literature on school financing is enormous. See, for example, the works collected in Annotation, Validity of Basing Public School Financing System on Local Property Taxes, 41 ALR3d 1220 (1972), and in Frug, Local Government Law at 522-23 (cited in note 31). See also Neuman, $135 \mathrm{U} \mathrm{Pa}$ L Rev at 372-82 (cited in note 3); Richard Briffault, The Role of Local Control in School Finance Reform, 24 Conn L Rev 773 (1992).

${ }^{317}$ Edgewood Independent School District v Kirby, 1991 Tex LEXIS 21 *5, $34 \mathrm{Tex}$ Sup J 368 (Feb 25, 1991).

${ }^{318}$ See, for example, Rose, $790 \mathrm{SW} 2 \mathrm{~d}$ at 211-12; Abbott, 575 A2d at 410; Helena Elementary School District, 769 P2d at 690-91. Even district power equalizing-the influential proposal for school finance reform advanced by John E. Coons, William H. Clune III, and Stephen D. Sugarman in Private Wealth and Public Education 200-42 (Harvard, 1970)-continued to allow residency to play a central ingredient in public school financing. See Briffault, 24 Conn L Rev at 776 (cited in note 316).

${ }^{119}$ See Christopher Alexander, A City is Not a Tree, 1/2 Zone 129, 144 (1986). Compare Felicity Barringer, Hire City Poor in the Suburbs, a Report Urges, NY Times D18 (Dec 4, 1992) (discussing Urban Institute report urging subsidized transportation between city and suburb), with Catherine Sullivan, Mayor Decries Post Mall Plan, New Haven Register I (Nov 10, 1992) (New Haven struggling against the expansion of suburban mall). 
locations of major sources of tax revenue, such as large suburban malls and office complexes, are often at some distance from the locations where the revenue is most needed. Localities within the region compete for these sources of revenue, just as they compete for the ability to exclude those who need government services. ${ }^{\mathbf{3 2 0}}$ But it is not necessary to organize the imposition and the dispersion of the property tax in terms of jurisdictional lines. Nor is it necessary to treat taxes on sales or income-taxes often paid by people who are not residents-as benefiting only residents. The current mismatch between the ability to raise revenue and the need for the money would be alleviated by a local government law that embraced the postmodern subject. Again, the critical issue (discussed below) is determining how best to do so.

It should be clear by now, I hope, that the transformation of local government law envisioned in this section would be dramatic. Almost no local government law issue would remain unaffected. To date only a few local government services-such as beaches-have been required to be open to residents and non-residents alike, ${ }^{321}$ and property-based tax schemes have been invalidated only in the area of school financing. But it is no more justifiable, in my view, for the quality of police protection, hospitals, or welfare programs to varyi with district wealth than it is for the quality of the schools. And the ability to support social programs in innovative ways should, like the power to raise taxes, not depend on where developers choose to put their office complexes. Some localities, for example, now condition zoning approvals for office buildings on the developers' agreement to subsidize low and moderate income housing-a practice known as "exactions." only if they can attract the developer, and developers have an incentive to shop around for a jurisdiction not interested in imposing such an exaction. If, however, an exaction could be imposed for the benefit of the region's poor wherever the development is located,

\footnotetext{
320 See generally Logan and Molotch, Urban Fortunes (cited in note 44).

321 See Matthews v Bay Head Improvement Association, 95 NJ 306, 471 A2d 355, 36066 (1984).

${ }^{322}$ See, for example, Stewart E. Sterk, Competition Among Municipalities as a Constraint on Land Use Exactions, 45 Vand L Rev 831 (1992); Vicki Been, "Exit" as a Constraint on Land Use Exactions: Rethinking the Unconstitutional Conditions Doctrine, 91 Colum L Rev 473 (1991); James E. Frank and Robert M. Rhodes, eds, Development Exactions (Planners, 1987).
} 
more such exactions would be possible and, as a result, more low and moderate income housing could be generated. ${ }^{323}$

In the interest of preserving a national economy, courts have long invoked the dormant Commerce Clause to prevent cities from favoring their own residents over outsiders. ${ }^{324}$ But court decisions relying on the Commerce Clause have simply invalidated local ordinances; they have not created a basis for a regional system of revenue-sharing and service-entitlement. A local government law founded on the postmodern subject has a chance of doing so. To be sure, as Justice Brennan suggested in Holt, a decision not to build local government law on local boundary lines and residency challenges our basic conception of what it means to be a political community. "At the heart of our basic conception of a "political community," "Justice Brennan asserted, "is the notion of a reciprocal relationship between the process of government and those who subject themselves to that process by choosing to live within the area of its authoritative application." ${ }^{325}$ Indeed, building local government law in terms of the ageographical city raises the question of what decentralization means. To whom would power be decentralized if not to people defined within local boundaries? And where would people participate in the democratic process if not at their place of residence?

\section{The Institutional Implications of Postmodern Subjectivity}

Many who write in the postmodernist tradition would consider it a very odd idea to try to build an institutional structure on postmodern subjectivity. After all, the postmodern subject, as described above, resists legal and institutional forms. S/he seeks to escape established structures through "subversive repetition," irony, and play, not to create them. ${ }^{328}$ Nevertheless, given the account of contemporary American metropolitan areas just advanced, there are very practical reasons to try to figure out how localities can best be endowed with this kind of subjectivity. Many of America's giant shopping malls and office complexes are private businesses located in areas where few people live. What is the role

${ }^{32 s}$ Of course, a developer might seek to shop among regions until he finds one that would not impose such an exaction. But regions could protect themselves from such an exercise of power through inter-regional cooperation. See Frug, 19 Urban Law 553 (cited in note 92).

s24 See, for example, Dean Milk Co. $v$ City of Madison, 340 US 349, 354-56 (1951).

s2s Holt Civic Club, 439 US at 82 (Brennan dissenting).

${ }^{326}$ See note 250 and accompanying text. 
of democracy in places like these? If we can't democratize Tyson's Corner or King of Prussia-when so many American downtowns have been superseded by developments of this kind-a vast amount of American life will never be subject to popular participation and control. ${ }^{327}$ And the disjunction between the locations where America's commercial and business life is growing and the centers of population is just an example of the urgent need to reconsider the mix of place-bites that constitute America's urban areas. In countless ways, the current mix combines, yet separates, areas of crushing poverty and elaborate wealth. If increasing the power of America's poor suburbs and inner cities to tax their own residents is unlikely to help them improve the lives of their citizens, and if the notion of the situated subject is too romantic or idealistic to affect the current city/suburb structure, perhaps postmodern theory is our most promising source of ideas for changing the present-day allocation of power in metropolitan areas.

One way postmodern subjectivity might be introduced into local government law is through a modification of the regional legislature proposed in Part II. There, the regional legislature was imagined in terms of the representation of neighborhoods, with each neighborhood defined by residency. If, however, as argued above, people have multiple attachments to the metropolitan area, including attachments to places where they shop or work (like Tyson's Corner or King of Prussia), a different system of representation might be better. Consider a plan, for example, in which everyone gets five votes that they can cast in whatever local elections they feel affect their interest ("local" still being defined by the traditional territorial boundaries of city, suburb, or neighborhood). They can define their interests differently in different elections, and any form of connection that they think expresses an aspect of themselves at the moment will be treated as adequate. Under such an electoral system, mayors, city council members, and neighborhood representatives in the regional legislature would have a constituency made up not only of residents but of workers, shoppers, property owners in neighboring jurisdictions, the homeless, and so forth. People are unlikely to vote in a jurisdiction they do not care about, but there are a host of possible motives for voting (racial integration, racial solidarity, redistribution of wealth, desire for gentrification, etc.). Indeed, there is no reason to think that the 
constituency would be limited solely to those who live in the region. These days, as I have already argued, people feel connected to areas far away as well as close to home. Puerto Ricans in New York, therefore, may want to vote not only in New York but in San Juan; of course, if they do, that would leave them one less vote for local elections in the New York region. ${ }^{328}$ On the other hand, the voting system might also mimic the idea of proportional representation by allowing someone to cast all five votes in one locality if that is where her/his attachments are felt to be. ${ }^{328}$

What exactly would happen under such a electoral allocation is hard to say: indeed its unpredictability might be felt to reproduce the sense of "vertigo" that life in metropolitan areas is now said to induce. ${ }^{330}$ All we know for sure is that members of the regional legislature, elected in such a manner, would allocate entitlements (as proposed in Part II) for decentralized decisionmaking by officials elected in the same manner. It seems likely, however, that the property tax generated by giant shopping malls and office complexes will be allocated more broadly than simply to those who live within the borders where they are located. Indeed, the rules for the allocation of all property taxes by the regional legislature could easily have a better chance of meeting the needs of people throughout the metropolitan area than negotiations between the city and the suburbs (defined in terms of residency). The attempt to limit services to those "inside" an area is also likely to be rethought and, perhaps, replaced with another form of allocation. Most importantly, such an electoral scheme would radically change the idea of what a neighborhood or suburb or city is-of who is included in a reference to such a locality. The "self" in the phrase local self-interest would become a gesture toward an unknown and unspecifiable multiplicity.

${ }^{328}$ A postmodern subjectivity provides regions with no more definite a boundary than cities or suburbs. Nevertheless, as long as voting areas remain defined in territorial terms, I suspect that most votes in local elections will be cast by voters within their own metropoli$\tan$ area. Occasional local issues (gay rights) may well attract voters from around the country, but interest in most local issues is likely to remain local.

329 For an analysis of this form of proportional representation as well as others, see Note, The Constitutional Imperative of Proportional Representation, 94 Yale L J 163 (1984). For a discussion of the impact of "proportionate interest representation" on black electoral success, see Lani Guinier, The Triumph of Tokenism: The Voting Rights Act and the Theory of Black Electoral Success, 89 Mich L Rev 1077 (1991). For an argument that lottery voting would be preferable to proportional representation, see Note, Choosing Representatives by Lottery Voting, 93 Yale L J 1283 (1984) (Akhil Amar was the student author).

sso See text accompanying note 281 . 
Still, the change would not be quite as radical as it might at first appear. The idea that Puerto Ricans who live outside of San Juan have an interest in being represented in its governance is not mine. Attempts have already been made to recognize their interests in the organization of San Juan's municipal government. ${ }^{331}$ Even the Supreme Court recognized, in Kramer $v$ Union Free School District, ${ }^{332}$ that those who vote in school board elections could not be limited to people who own or lease property in the area, their spouses, and the parents or guardians of the children who attend the schools. Many others, the court reasoned, have a direct and distinct interest in school decisions: "senior citizens and others living with children or relatives; clergy, military personnel, and others who live on tax-exempt property; boarders and lodgers; parents who neither own nor lease qualifying property and whose children are too young to attend school; parents who neither own nor lease qualifying property and whose children attend private schools." "333 But why stop there? Many more-including many nonresidents the Court did not consider-are just as interested: teachers and staff who work at the school; parents who would like to send their children to the school system if they weren't excluded by residency requirements; parents who are sending their children to schools with fewer resources; citizens who believe in school integration. ${ }^{3 s 4}$ Of course, adding this group to the list of residents that

s31 See Ortiz v Hernandez Colon, 385 F Supp 111, 113-14 (D PR 1974), vacated as moot, 429 US 1031 (1977). Ortiz held the voting scheme unconstitutional, but a principal defect of the scheme was that the people who were to represent the non-residents of San Juan were not elected but were appointed by the Governor (only those living in Puerto Rico were to be represented). Id at 118-19.

ss2 395 US 621 (1969).

sss Id at 630 .

s3s In Fumarolo $v$ Chicago Board of Ed., 142 Ill 2d 54, 566 NE2d 1283 (1990), the Supreme Court of Illinois held unconstitutional the Chicago School Reform Act, which had created ten-member local school councils for each grammar and high school in the Chicago public school system. The elected members of the councils, which had significant powers over school policy, included six parents of currently enrolled students elected by the parents, two area residents elected by the area residents, and two teachers elected by the school staff. Relying on Kramer, 395 US 621 , the court held that, by giving parents the decisive voice in school policy, the Reform Act unconstitutionally diluted the interest of other potential voters. "The Act plainly gives certain voters who may have little or no interest in the local school a weighted vote, e.g., a parent who has left the family and has no significant contact with or interest in the child, the community or its local school, while significantly limiting the weight of the vote of a section of the community that may have a strong interest in the school, e.g., property owners concerned with the value of their property and families with children of preschool age." 566 NE2d at 1300 . This reasoning is not only in considerable tension with the argument for local control advanced in Rodriguez, 411 US at 49-50, (see note 315 and accompanying text), but would undermine the rationale for any residency- 
the Court did include would make the school's constituency very uncertain and unstable. But school constituencies are already uncertain and unstable: residents are constantly moving in and out. In our mobile society, the notion of residency has provided an ever-shifting referent for the population of school districts, neighborhoods, and cities; in fact, reliance on residency has demonstrated that a fixed population is unnecessary to define a political constituency. Constituencies are defined tautologically: a locality includes whoever is defined by its rules of inclusion. And there is no reason to interpret the Constitution as requiring the rule of inclusion to be residency. ${ }^{395}$

A local government law based on a postmodern subjectivity also need not respect the current territorial boundaries of cities and towns, as has so far been assumed. Even now the residents of America's metropolitan areas live in a multitude of legally-defined jurisdictions with different borders: the areas defined by school districts, transportation districts, redevelopment authorities, park districts, and the like often differ not only from city borders but from each other. ${ }^{338}$ Currently, however, each of these governmental agencies reproduces the model of the centered subject adopted by cities: special districts and public authorities serve those defined by their borders. Thus the experience of the loss of boundaries that might have been produced by the multiple definitions of each citizen's location within the metropolitan area has been eclipsed by the reassuring sense that one's location is defined by the purpose of each territorial definition (the fact that you're in the same Con-

controlled school system once the arbitrariness of the resident/non-resident distinction is recognized.

sss Although a residency requirement is constitutionally permissible, see Tribe, American Constitutional Law $\S 13-12$ at 1088-91 (cited in note 59), it does not follow that limiting the franchise to residents is constitutionally required. After all, including non-residents in the voting pool would still allow all eligible voters to have an equal (one person, one vote) voice in the electoral process. Thus a locality's decision to include summer residents in the franchise has been held constitutional, see Glisson $v$ Mayor of Savannah Beach, 346 F2d 135, 136-37 (5th Cir 1965), although the decision was made before Avery v Midland County, 390 US 474 (1968), applied the "one person, one vote" standard to localities (but after Reynolds $v$ Sims, 377. US 533 (1964), established the "one person, one vote" constitutional standard). Compare Brown v Board of Commissioners of the City of Chattanooga, $722 \mathrm{~F}$ Supp 380, 397-400 (E D Tenn 1989) (agreeing with Glisson but rejecting Chattanooga's inclusion of non-resident property owners in the city franchise on the grounds that its definition of property owners was unacceptable). See also Bjornestad v Hulse, 229 Cal App 3d 1568, 281 Cal Rptr 548 (1991) (approving non-resident voting in the election of a water district's board of directors, and reviewing earlier cases approving the inclusion of town residents in the voting pool for county school officials).

${ }^{s s 6}$ See, for example, US Bureau of Census, Governmental Organization, 1 Census of Governments x-xiii (1982); works cited in note 192. 
gressional district as someone else doesn't mean that your kids can go to her school). Endowing localities with a postmodern subjectivity would replace this comforting feeling with an intensified experience of geographic dissonance. Bringing even just the current multiplicity of boundaries to consciousness can help undermine the boundary-fixation that characterizes so much of present-day local government law.

One form this consciousness-raising could take would be to increase the level of popular participation in the multitude of territorially-defined governmental bodies that now exist within a metropolitan area. At present their bureaucratic structure renders the differences among their boundary definitions virtually invisible; only insiders pay much attention to how the area is divided up. If, however, members of the public worked together on education, parks, transportation, and similar issues, they would begin to recognize the uncertainties of defining who counts as part of their community. Moreover, this experience need not be confined to currently existing agencies. Often it would be better to set up a series of temporary task forces-ad-hoc organizations-created to solve specific problems and disbanded after the task is completed. The temporary character of these task forces would make it easier for people to participate than in permanent organizations. And the task forces could divide up the region in new ways to examine aspects of metropolitan life now largely left untouched: the need for better working conditions in offices (a region of buildings), the need for health and retirement benefits for people who work in others' houses (a region of domestic workers), the need for childcare facilities (a region of kids), the need for consumer protection (a region of shoppers). I have discussed proposals for participation and "adhocracy" such as these in greater detail elsewhere. ${ }^{337}$ At the moment I am raising them simply as examples of ways to provoke in the minds of local residents the kind of questions associated with the postmodern subject ("Which world is this? What is to be done in it? Which of my selves is to do it? ... What happens when different kinds of world are placed in confrontation, or when boundaries between worlds are violated?"). ${ }^{\text {s38 }}$

Another form that postmodern subjectivity in local government law might take would question not whom the locality includes but the kinds of functions it performs. So far, the discussion of localities has referred only to the traditional tasks of municipal

\footnotetext{
s97 Frug, 40 Toronto $L \mathrm{~J}$ at 577-79 (cited in note 11).

ssa McHale, Postmodernist Fiction at 9-10 (cited in note 246).
} 
governments, such as zoning, condominium conversion, school financing, and allocation of public services. But this limited view of the role of local government is by no means necessary. David Osborne and Ted Gaebler, for example, have sought to "reinvent government" on a model of entrepreneurial activity. ${ }^{339}$ Localities, they argue, should see themselves as profit-oriented market-innovators and entrepreneurs, not as regulators and lawmakers. They should serve as catalysts for economic development, foster community-run organizations, and organize their own activities to increase worker participation. I have made similar proposals for this kind of change myself. ${ }^{340}$ But my ideas, like theirs, treated local territorial boundaries as given. I now think it would be better to combine these ideas with the other proposals advanced in this section, spreading their risks and benefits across the region rather than having each locality undertake entrepreneurial activities as a separate entity (defined in terms of residency). But whether organized locally or inter-locally, these proposals illustrate one more way to destabilize the identity of localities: Osborne and Gaebler (and I) make the application of the public/private distinction to local governments impossible.

\section{Beyond the Postmodern Subject}

Building a local government law on postmodern subjectivity would help transform America's metropolitan areas into "switching center[s] for all ... [their] networks of influence."\$41 Not only boundaries but the sense of community they engender would disappear. For some people, such an "end of interiority and intimacy" ${ }^{342}$ would be precisely the problem with these proposals. The last kind of future they hope to promote is the world of the ageographical city. They therefore would look, in many possible directions, for something beyond the postmodern subject. I would like to address here only one of the possible beyonds: beyond the postmodern subject might lie the situated subject.

I argued earlier that the situated subject suffers from romanticism and hedging. ${ }^{343}$ The postmodern subject, by contrast, suffers

\footnotetext{
sss David Osborne and Ted Gaebler, Reinventing Government: How the Entrepreneurial Spirit is Transforming the Public Sector (Addison-Wesley, 1992).

${ }^{310}$ See Frug, 40 U Toronto L J at 563-66 (cited in note 11); Frug, 1984 Am Bar Found Res $J$ at 687-91 (cited in note 52); Frug, 93 Harv L Rev at 1128, 1150 (cited in note 11).

s41 Baudrillard, Ecstasy of Communication at 133 (cited in note 245). See text accompanying note 245 for a larger quote.

342 Id.

sts See text accompanying notes 209-20.
} 
from a lack of romanticism and from relentlessness. Postmodernists and the ageographical city seem to lack an ingredient many people find essential: the feel of human connection. The postmodernists' relentless irony and self-conscious, playful presentation of self often come across as inauthentic; their concentration on appearances-their rejection of the modernist search for a truth beneath the surface ${ }^{344}$-undermines others' experience of being in touch with who the person really is. The postmodern city feels similarly cold and distant: the disbelief in neighborhood cohesion, let alone that of the city and the suburb, renders not only inter-group but intra-group relations hard to understand. Being connected everywhere seems the equivalent of being connected nowhere (and to no one): not only $I$ but we becomes a word with no particular meaning.

Indeed, viewed from the perspective of a situated subject, postmodern subjectivity shares all too much with centered subjectivity. Centered subjects also seem distant, cold, and lacking in human connection; their inability to relate to others may be attributed to self-interest rather than lack of authenticity, but the two positions may nevertheless be experienced as indistinguishable. Postmodern local government law might even be thought to offer less of a sense of connection than current law: at least it allows for a group cohesion within local boundary lines. Of course, the problem with current local government law is that its view of community is too truncated; it divides communities and people by creating too many boundaries. Postmodern local government law divides communities and people by creating too few boundaries. ${ }^{\mathbf{3 4 5}}$ Both the centered and postmodern forms of subjectivity thus lack just what the situated subject wants most: the capacity to nurture a sense of community. To promote the idea of community, then, one needs to move beyond not only the centered subject but the postmodern subject as well.

Of course, a postmodernist response to this critique could easily link the situated subject's longing for community with the centered subject's longing for self: both hunger for the same thing-an

\footnotetext{
${ }^{344}$ See, for example, Jameson, Postmodernism at 6-16 (cited in note 241).

346 For an analysis of the importance of congestion, landmarks, and a sense of place in urban life, see Lynch, Image of the City (cited in note 277); Whyte, City (cited in note 179). For a discussion of Los Angeles in these terms, see Lynch, Image of the City at 32-43 (cited in note 277); Fishman, Bourgeois Utopias at 155-81 (cited in note 8) (Los Angeles has "its own novel form: decentralized congestion," id at 157).
} 
(unachievable) sense of wholeness and togetherness. ${ }^{348}$ Postmodernists have a different idea of community, one more in tune with the feel of Los Angeles or Las Vegas or Disneyland than of small town America or a commune. ${ }^{347}$ To a postmodernist, it is the situated subject who seems indistinguishable from the centered subject. Both are so earnest, so obsessively focused on fulfilling some personal mission. Neither could possibly understand (what some postmodernists might think of as) the real reason behind this section's reform of local government law: neither would think it relevant, let alone decisive, that it would be so much fun to have an electoral system with everyone having five votes usable where ever s/he likes. The earnest, focused, serious form of politics of the situated subject, like that of the centered subject, demands a more inspired goal. And it requires more than can possibly be known in advance about the results of political activity. The postmodern subject might well prefer the devastating politics of laughter.

This Article has advanced a third reading of the relationship among the three subjectivities: it has presented the situated subject and the postmodern subject as alternatives to the notion of the centered subject. Both reject the centered subject's focus on boundary lines, an emphasis that so far has dominated thinking about local government law. Both refuse to treat cities as if they are individual units that have a relationship only with the state; both seek instead to build a form of metropolitan life in which people across the region learn to recognize, and make policy on the basis of, their interactions with each other. At the same time, both are post-integration visions of America. Of course, integration remains possible, but it is no longer a master goal. Either version of

${ }^{34}$ For example, Michael Sandel argues for the situated self when he discusses individuals, but he uses the language of the centered subject when he argues for local control for communities. See Michael J. Sandel, Democrats and Community: A Public Philosophy for American Liberalism, New Republic 20 (Feb 22, 1988).

37 For efforts to articulate a postmodern idea of community, see Sennett, Conscience of the Eye (cited in note 146); Jean-Luc Nancy, The Inoperative Community (Minnesota, 1991); Miami Theory Collective, ed, Community at Loose Ends (Minnesota, 1991); Drucilla Cornell, The Poststructuralist Challenge to the Ideal of Community, 8 Cardozo L Rev 989 (1987); Ernesto Laclau and Chantal Mouffe, Hegemony and Socialist Strategy: Towards a Radical Democratic Politics (Verso, 1985). For the literature on Los Angeles, see works cited in note 283. On Las Vegas, see, Robert Venturi, Denise Scott Brown, and Steven Izenour, Learning From Las Vegas (MIT, 1977). On Disneyland-a central image in postmodern writing-see, for example, Baudrillard, Simulations at 23-26 (cited in note 12); Michael Sorkin, See You in Disneyland, in Sorkin, ed, Variations on a Theme Park at 205 (cited in note 141). For an alternative reading of Disneyland-offering it as an example of the coherence of a Western urban identity-see John M. Findlay, Magic Lands: Western Cityscapes and American Culture After 1940 52-116 (California, 1992). 
regional negotiations allows people to form their own communities (defined by notions of race; ethnicity, class, sexual orientation, gender, or whatever); it's just that they cannot do so without confronting people in other communities-as well as dissidents in their own communities-whose lives they affect. Above all, both alternatives reject the current social policy of current local government law and the form of consciousness that it fosters, one that has fragmented our metropolitan areas into areas of privilege and want, us vs. them. The kind of metropolitan life that either version would foster no doubt differs. But in both cases decentralization means the ability to participate actively in the basic societal decisions that affect one's life, ${ }^{348}$ not the ability to mimic state or national power on the local level.

I will not-cannot-resolve the choice between the situated and the postmodern subject. I am very attracted to both views. After all, why else would I have written this Article? To me the two positions may be irreconcilable but they are indispensable. In the language of the situated subject, they replicate the contradictory experience of community: the desire for connection with others and the desire for the feel of the modern metropolis. In the language of the postmodern subject, they allow me to live out contradictory versions of (my)self. Indeed, readers who prefer the situated self are likely to have found my presentation of that position too deconstructive, ${ }^{349}$ while those more in tune with the postmodern self could easily have found the presentation of that idea too earnest. ${ }^{350}$ Of course it would be very odd, here at the end of this long article about the decentered subject, for me to try to center myself in one or the other of these versions. Besides, there is no need for me to do so. These two models of subjectivity do not exist: they are my own creations. It would be ridiculous to imagine being forced to make a choice between them-or to imagine that there are not thousands of other choices as well. The purpose of this Article is not to spell out a policy that others simply might implement. Readers have to make the text their own. ${ }^{\text {s51 }}$ If this effort has been successful, it will be because it would have persuaded you to engage with me (too situated a phrase? how about: because

\footnotetext{
348 Gerald E. Frug, Cities and Homeowners Associations: A Reply, $130 \mathrm{U} \mathrm{Pa} \mathrm{L}$ Rev 1589, 1599 (1982); Frug, 93 Harv L Rev at 1068 (cited in note 11).

${ }^{349}$ For example, in my emphasis on the differences within, not between, cities and suburbs. See text accompanying note 181 .

${ }^{380}$ See, for example, Section III.C.

251 See Jerry Frug, Argument as Character, 40 Stan L Rev 869 (1988).
} 
it can become an object for you to play with) in the reinvention of our metropolitan areas.

\section{CoNCLUSTON}

In the center of Fedora, that gray stone metropolis, stands a metal building with a crystal globe in every room. Looking into each globe, you see a blue city, the model of a different Fedora. These are the forms the city could have taken if, for one reason or another, it had not become what we see today. In every age someone, looking at Fedora as it was, imagined a way of making it the ideal city, but while he constructed his miniature model, Fedora was already no longer the same as before, and what had been until yesterday a possible future became only a toy in a glass globe.

The building with the globes is now Fedora's museum: every inhabitant visits it, chooses the city that corresponds to his desires, contemplates it, imagining his reflection in the medusa pond that would have collected the waters of the canal (if it had not been dried up), the view from the high canopied box along the avenue reserved for elephants (now banished from the city), the fun of sliding down the spiral, twisting minaret (which never found a pedestal from which to rise).

On the map of your empire, $\mathrm{O}$ Great Khan, there must be room both for the big, stone Fedora and the little Fedoras in glass globes. Not because they are all equally real, but because all are only assumptions. The one contains what is accepted as necessary when it is not yet so; the other, what is imagined as possible and, a moment later, is possible no longer. ${ }^{362}$ 